\title{
Lægers kontekstualisering af klinisk information
}





\section{Lægers kontekstualisering af klinisk information}

PhD-afhandling af

Gert Galster

Medicinsk Informatik, Institut for Medicin og Sundhedsteknologi, Det Sundhedsvidenskabelige Fakultet, Aalborg Universitet, Denmark

River Publishess

Aalborg 
ISBN 978-87-93102-82-8 (e-book)

Published, sold and distributed by:

River Publishers

Niels Jernes Vej 10

9220 Aalborg Ø

Denmark

Tel.: +45369953197

www.riverpublishers.com

Copyright for this work belongs to the author, River Publishers have the sole right to distribute this work commercially.

All rights reserved (c) 2014 Gert Galster.

No part of this work may be reproduced, stored in a retrieval system, or transmitted in any form or by any means, electronic, mechanical, photocopying, microfilming, recording or otherwise, without prior written permission from the Publisher. 


\section{Indholdsfortegnelse}

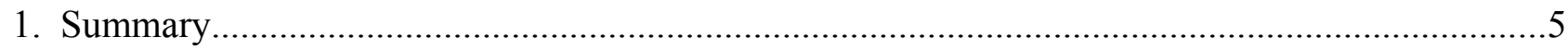

2. Resumé

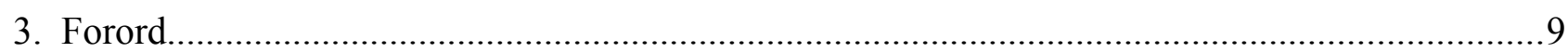

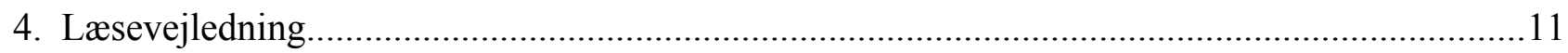

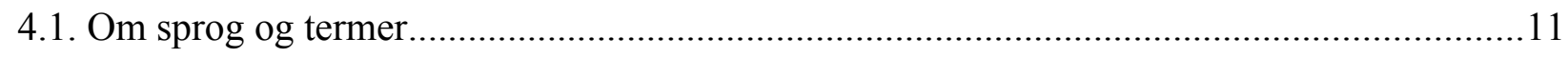

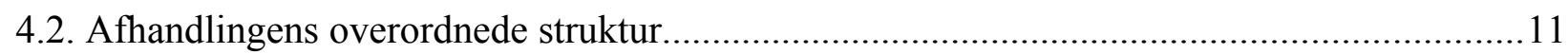

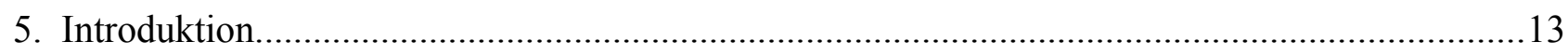

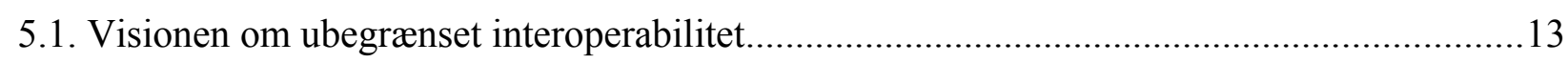

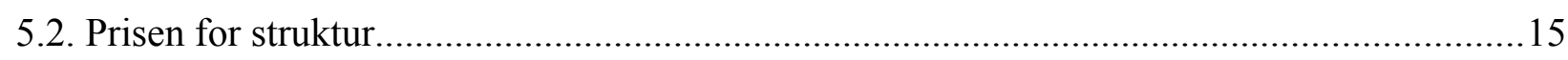

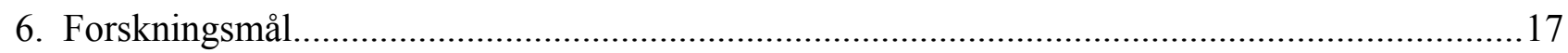

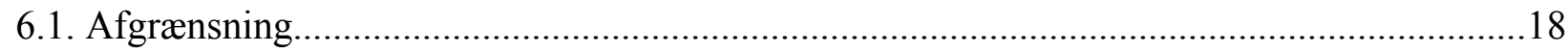

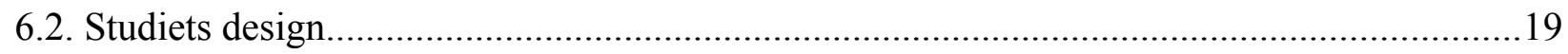

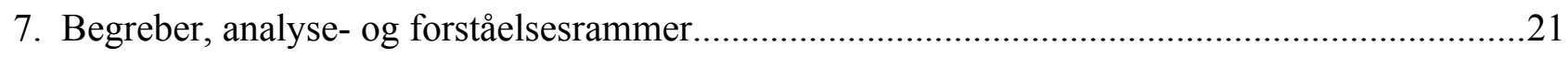

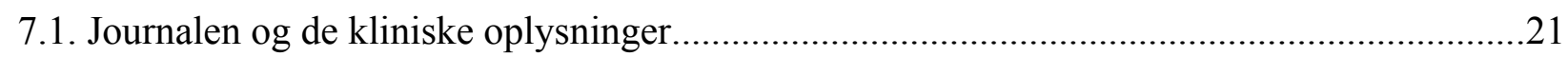

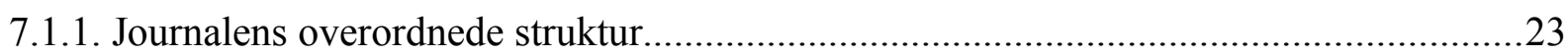

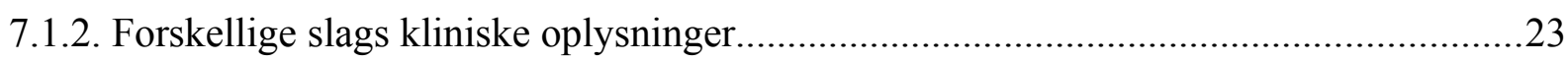

7.1.3. Forståelsesramme for klinisk information i journalen..................................................24

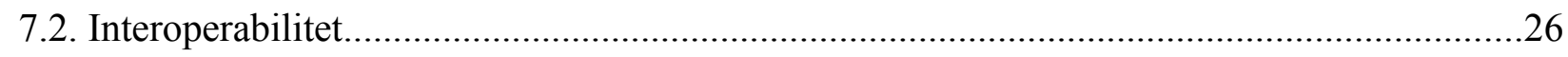

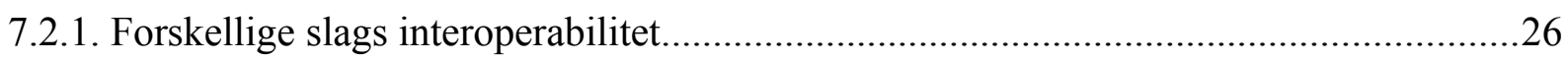

7.2.2. Visionen om ubegrænset pragmatisk interoperabilitet...................................................28

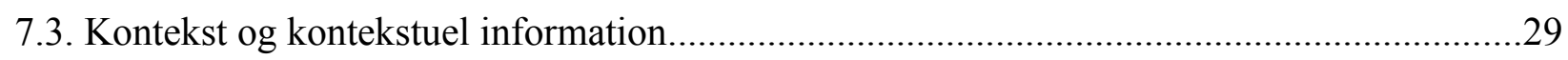

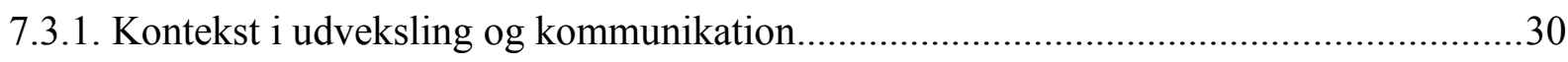

7.3.2. Kontekst $i$ forhold til anvendelse af klinisk information.................................................

7.3.3. Forskellige opfattelser af kontekst(uel information).......................................................32

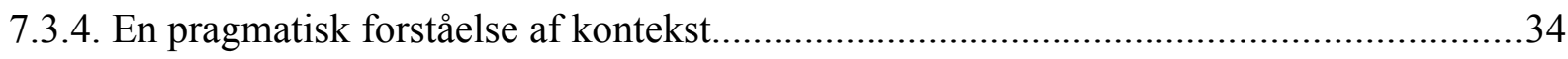

7.3.5. Forståelsesramme for kontekstuel information i journalen..............................................35

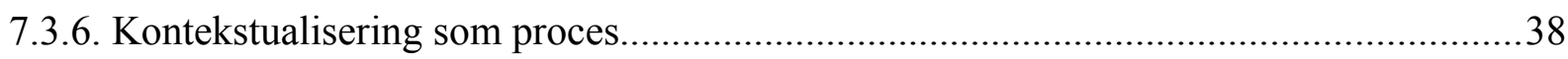

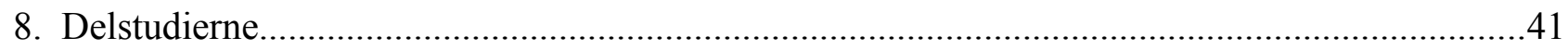

8.1. Teoretisk studie af kontekstuel klinisk informations betydning for klinisk arbejde................42

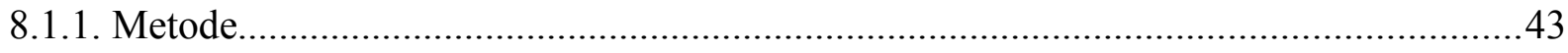




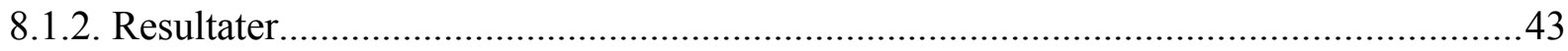

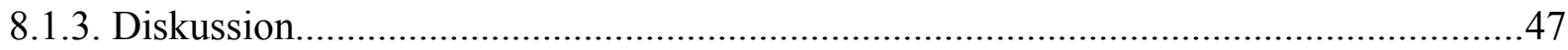

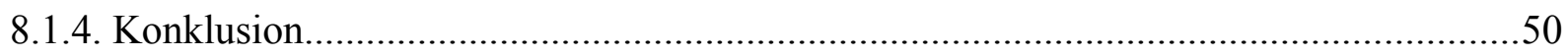

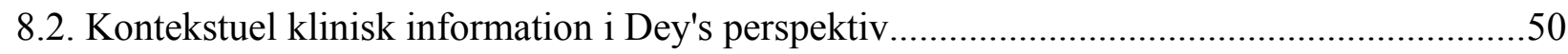

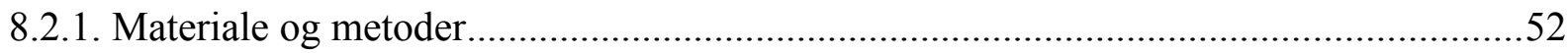

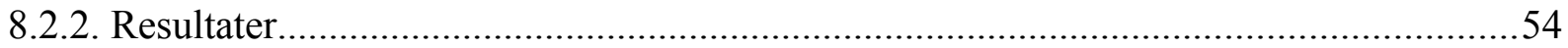

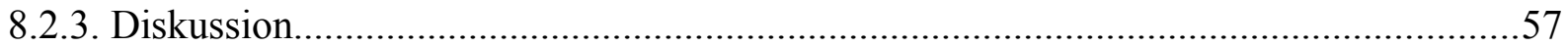

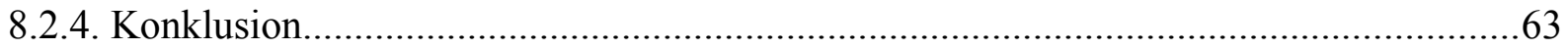

8.3. Kontekstuel klinisk information i Dourish's perspektiv.................................................63

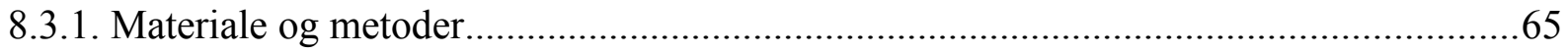

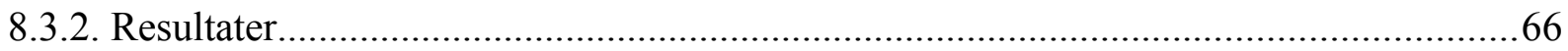

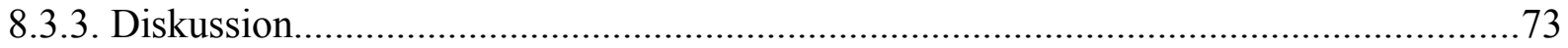

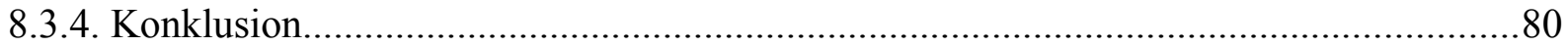

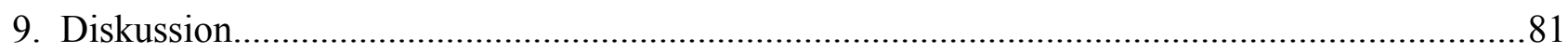

9.1. Hvad er kontekstuel klinisk information for læger? Og hvilken betydning har den for deres

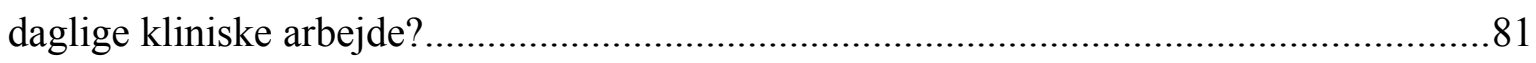

9.2. I hvilket omfang kan kontekstuel klinisk information operationaliseres med henblik på at un-

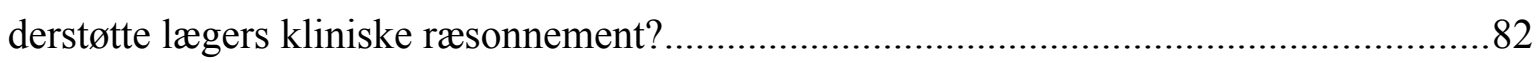

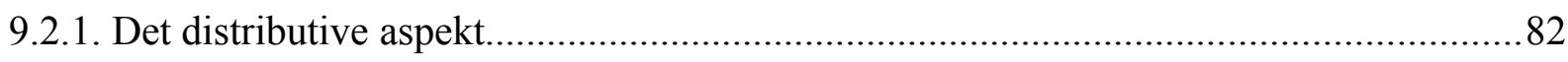

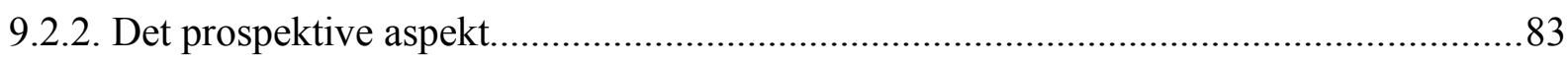

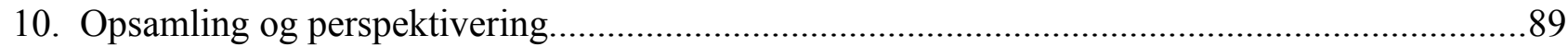

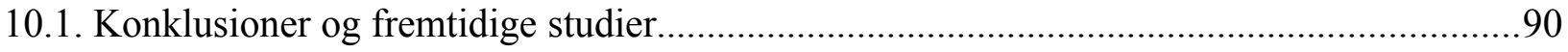

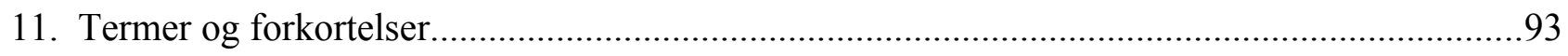

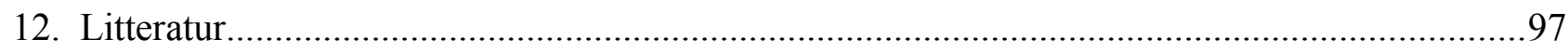

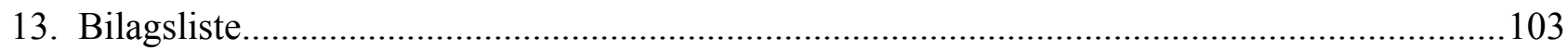




\section{Summary}

The processing of clinical information constitutes an essential part of doctors' daily work. Thus, clinical information systems are of key importance to health care. These systems - 'the health record' - have over the decades evolved from being the individual physician's personal, handwritten memo list towards being a digital collaborative tool for many various professions and stakeholders. As a consequence, there is an an increasing demand for interoperability of clinical information systems which is the main reason for structuring and standardization of clinical information. The increased structuring, however, gives rise to a decrease in communicative quality; simply because natural language is richer than structured language. The structuring of clinical information seems, in particular, to imply a loss of contextual content. Several studies have - based on examples - shown, that doctors must be able to access contextual clinical information. In the light of the increasing structuring of clinical information, it was thus of interest to examine what this type of information includes, and which role it plays.

This thesis is based on a literature study and two field studies which from two different perspectives on contextuality clarify what constitutes contextual clinical information, its importance, and how it can be operationalized.

The thesis defines and describes a subset of contextual clinical information relating to the circumstances in which clinical information is produced, i.e. production-contextual clinical information. The unhindered exchange of this type of information constitutes a condition for establishing pragmatic interoperability which is why several papers have recommended further structuring of clinical information. The thesis provides a number of reasons why the exchange of production-contextual clinical information necessarily has its limits, and states that the realisation of pragmatic interoperability in healthcare therefore is unattainable.

The thesis also describes a method to uncover and visualize the clinically logical information structure that doctors build during their contextualization of clinical information. It is shown how this method can be used to identify inappropriate information structures in clinical IT systems.

Finally, the thesis outlines some proposals for structural change of the health record which is expected better to support doctors' contextualization, and also can be used as the basis for a potent type of clinical decision support within the scope of existing technology. 



\section{Resumé}

At behandle klinisk information udgør en essentiel del af lægers arbejde, og kliniske informationssystemer er således et centralt værktøj. Disse systemer - 'journalen' - har over årtier ændret karakter fra at være den enkelte læges personlige, håndskrevne huskeseddel hen mod at være et digitalt, kollaborativt værktøj for mange forskellige faggrupper og interessenter. En konsekvens af denne udvikling er, at journalen underkastes et stigende krav om interoperabilitet, som har ført til en udvikling mod det mere strukturerede og standardiserede. En konsekvens af den øgede strukturering er imidlertid, at kommunikationen taber i kvalitet - ganske enkelt fordi naturligt sprog er rigere end struktureret sprog. I særlig grad synes man gennem strukturering at tabe kommunikationens kontekstuelle indhold. Flere arbejder har ud fra eksempler sandsynliggjort, at læger i deres arbejde har brug for at kunne tilgå kontekstuel information, og i lyset af den tiltagende strukturering af klinisk information var det derfor relevant at undersøge hvad denne type information omfatter, og hvilken rolle den spiller.

Denne afhandling er baseret på et litteraturstudie og to feltstudier, som med udgangspunkt i to forskellige paradigmer for kontekst belyser, hvad der udgør kontekstuel klinisk information, hvilken betydning den har, og hvordan den kan operationaliseres.

Afhandlingen definerer og beskriver en delmængde af kontekstuel klinisk information, som vedrører de omstændigheder, hvorunder kliniske oplysninger er tilvejebragt. Udveksling af denne type information - produktionskontekstuel klinisk information - udgør en betingelse for pragmatisk interoperabilitet, og flere arbejder har anbefalet, at den derfor underkastes strukturering og standardisering. Afhandlingen beskriver en række årsager til, at udveksling af produktionskontekstuel klinisk information nødvendigvis har sin begrænsning, og at fuld pragmatisk interoperabilitet indenfor sundhedssektoren derfor er uopnåelig.

Afhandlingen beskriver desuden en metode til at afdække og visualisere den klinisk-logiske informationsstruktur, som læger skaber i forbindelse med deres kontekstualisering af klinisk information. Det er i afhandlingen demonstreret, hvordan denne metode kan anvendes til at identificere uhensigtsmæssige informationsstrukturer i kliniske it-systemer.

Afslutningsvis skitseres nogle forslag til strukturelle forandringer af journalen, som forventes bedre at kunne understøtte lægernes kontekstualisering, og som med eksisterende teknologi kan danne grundlag for en potent type af klinisk beslutningsstøtte. 



\section{Forord}

There is no foreign land; it is the traveller only that is foreign.

Robert Louis Stevenson

Når jeg har fortalt kolleger, venner og bekendte, at mit arbejde handlede om kontekst og klinisk information, har jeg som regel fået at vide, at det er et vigtigt og relevant emne, og de har ofte beriget mig med supplerende eksempler fra deres opfattelse af kontekst. Det har i væsentlig grad bidraget til min forståelse af, at kontekst er ... kontekstuel.

Da jeg startede studiet, var jeg ikke i tvivl om, hvad kontekst og kontekstuel information var, og jeg forsøgte at angribe emnet fra en vinkel, som har præget mange års sundhedsinformatisk udvikling: dekomposition og modellering. Undervejs ændredes min opfattelse af kontekst, og derfor afspejler denne afhandling en lang række overvejelser om konteksts natur og mening. Jeg havde troet, at der for enden af regnbuen (dette studie ekstrapoleret mange trin fremad) lå en fin og struktureret pakke med kontekstuel klinisk information, som kunne udveksles og anvendes til klinisk ræsonnement. Der, hvor jeg står nu, synes der for enden af regnbuen at ligge en journal, som dynamisk hjælper læger med deres kontekstualisering. Jeg ser frem til at fortsætte arbejdet...

Dette studie har været en rejse med både op- og nedture, og jeg har lært meget undervejs. Om kontekst, om information, om videnskabelighed, om metode og ... om mig selv. Jeg vil gerne takke dem, der bidrog til denne rejse: Mine kolleger på AAU og de meget tålmodige læger på Bispebjerg og Frederiksberg Hospital.

Jeg vil gerne rette en speciel tak til min vejleder, Stig Kjær Andersen, som gjorde studiet muligt, til min kollega, Louise Pape-Haugaard, for gode råd og uforbeholden, konstruktiv kritik, til Tine Ditmar, som hjalp mig med det fremmedsprogede, og til min hustru, Pernille Stadel, for at give mig frirum til at skrive og for en masse faglig kritik og sparring. 



\section{Læsevejledning}

Denne afhandling henvender sig til sundhedsinformatikere med et godt kendskab til det sundhedsfaglige domæne. Der er bevidst valgt den autentiske fremstilling fremfor konstruerede eksempler, og der benyttes medicinske fagtermer og refereres indforstået til den virkelighed, som dagligt møder sundhedsarbejdere.

\subsection{Om sprog og termer}

Selvom denne afhandling er skrevet på dansk, optræder der flere steder engelske passager i teksten. Dels på grund af et ønske om at citere med præcision frem for at citere gennem oversættelse, dels fordi der er udtryk (fx. context-aware computing, ubiquitous computing, user experience), som det ville være meningsforstyrrende at fordanske.

Enkelte termer (fx. 'journal') har i denne afhandling en betydning, som er skarpere defineret end i dagligdags sprog. Det anbefales derfor at benytte term- og forkortelseslisten i kapitel 11, side 93.

I de få tilfælde, hvor der i denne afhandling er refereret til en enkelt læge (læger i ental), er lægen betragtet som en kvinde og refereret til med termerne "hun" og "hende". Der ligger heri ikke andet end et konsekvent valg af termer.

\subsection{Afhandlingens overordnede struktur}

Denne afhandling tager afsæt i konsekvenserne af at strukturere klinisk information med henblik på opnå interoperabilitet. Den overordnede baggrund er beskrevet i Introduktionen i næste kapitel, hvorefter følger beskrivelsen af studiets Forskningsmål og design, kapitel 6.

Som nævnt har fortolkning og forståelse haft en fremtrædende plads i studiet. Det teoretiske grundlag er beskrevet i Begreber, analyse- og forståelsesrammer, kapitel 7.

Studiet er baseret på et litteraturstudie og to feltstudier, der tilsammen er beskrevet som Delstudierne, kapitel 8. De tre delstudier er desuden delvist beskrevet $\mathrm{i}$ form af fire papers, der her er vedlagt som Bilag 1 - 4.

Diskussionen, kapitel 9, indeholder en fremstilling af de opnåede resultater med en efterfølgende Opsamling og perspektivering, kapitel 10.

Et væsentligt aspekt i denne afhandling har været at forstå, definere og afgrænse en række abstrakte begreber. Det tilgrundliggende værktøj hertil er sproget, og det har derfor været et mål at skrive 
med præcision, herunder at anvende termer på en konsekvent måde og refererende til veldefinerede begreber. Anvendte termer er anført i Termer og forkortelser, kapitel 11.

Endelig indeholder Litteratur, kapitel 12, en liste over de refererede kilder. Bilagene er anført i Bilagslisten, kapitel 13. 


\section{Introduktion}

\subsection{Visionen om ubegrænset interoperabilitet}

Udvikling af sundheds-it har stået på i godt 40 år. Lokale, nationale og internationale initiativer har lagt betydelige ressourcer i udviklingen, og i takt med den samtidige teknologiske udvikling har ambitionsniveauet gradvist flyttet sig fra udvikling af små, enkeltstående, lokale systemer med begrænset funktionalitet og scope, til en ambitiøs vision om ubegrænset tilgængelighed og anvendelse af kliniske oplysninger. Denne vision afspejler sig fx. i det scoringssystem, som HiMSS har udviklet til at vurdere hospitalers digitale modenhedsgrad[1], hvor den højeste grad af modenhed beskrives således:

Stage 7: The hospital no longer uses paper charts to deliver and manage patient care and has a mixture of discrete data, document images, and medical images within its EMR environment. Clinical Data Warehouses are being used to analyze patterns of clinical data to improve quality of care and patient safety and to feed outcomes reports, Quality Assurance, and Business Intelligence. The hospital demonstrates summary data continuity for all hospital services (e.g. inpatient, outpatient, ED, and with any owned or managed ambulatory clinics). Clinical information can be readily shared via standardized electronic transactions (e.g. Continuum of Care Document) with all entities who are authorized to treat the patient, or a health information exchange (i.e., other non-associated hospitals, ambulatory clinics, sub-acute environments, employers, payers and patients in a data sharing environment).[1]

Visionen om ubesværet deling og anvendelse af klinisk information kommer tydeligere til udtryk i nationale strategier, som det fx. blev udtrykt af det engelske NHS i 1998[2]:

... the strategy commits to:

- lifelong electronic health records for every person in the country

- round-the-clock on-line access to patient records and information about best clinical practice, for all NHS clinicians

- genuinely seamless care for patients through GPs, hospitals and community services sharing information across the NHS information highway

- fast and convenient public access to information and care through on-line information services and telemedicine

- the effective use of NHS resources by providing health planners and managers with the information they need.[2] 
eller af den danske Sundhedsstyrelse i 2003[3]:

Information retrieval can be done with equal ease across all providers' contributions, it can be ascertained whether a certain piece of information does exist, and most importantly all information can be reused for a variety of purposes including decision support, automatic booking, quality assurance \& development, and research.[3]

En af de mest udførlige beskrivelser af denne sundhedsinformatiske vision er formuleret af det EUfinansierede SemanticHEALTH-projekt, hvis formål var - på europæisk niveau - at udvikle en langsigtet køreplan for forskning i og implementering af semantisk interoperabilitet. Projektet skulle identificere de vigtigste skridt i retning af at realisere semantisk interoperabilitet på tværs af sundhedssystemer med fokus på, hvorledes genbrug af kliniske oplysninger kan understøtte pleje og behandling, forskning og sundhedsadministration. I 2009 udgav projektet rapporten "Semantic Interoperability for Better Health and Safer Healthcare"[4] (herefter benævnt: 'SemanticHealth-rapporten'), hvori man eksplicit beskrev den tilsigtede grad af interoperabilitet i sundheds-it:

Health system interoperability is the ability, facilitated by ICT applications and systems,

- to exchange, understand and act on citizens/patients and other health-related information and knowledge

- among linguistically and culturally disparate health professionals, patients and other actors and organisations

- within and across health system jurisdictions in a collaborative manner.[4]

SemanticHealth-rapporten tegnede videre med uddybning og cases en forståelse, hvor semantisk interoperabilitet ikke blot betyder, at begreber overføres uden tab af meningsindhold, men at de desuden opfattes og fortolkes, som om informationen var skabt lokalt, og at de således direkte kan anvendes som grundlag for kliniske overvejelser og beslutninger.

Rapporten anbefalede en række tiltag for at realisere visionen. Udover et antal organisatorisk-politiske tiltag anbefalede man intensiveret standardisering og strukturering af klinisk information gennem anvendelse af modeller (arketyper, 13606-standarden) og terminologier (SNOMED-CT, ICD) [4]. Disse anbefalinger er ikke overraskende set i lyset af, at de beskriver fortsættelsen af en årelang sundhedsinformatisk trend af modellering og udvikling af terminologier. 


\subsection{Prisen for struktur}

I modsætning til SemanticHealth-rapportens anbefaling af standardisering og strukturering er det $\mathrm{i}$ flere arbejder, fx. [5-8], blevet problematiseret, at klinisk information i stedse stigende grad bliver underkastet strukturering, fordi man derved taber kontekst og meningsindhold:

The clinical notes expressed in natural language will, for the foreseeable future, be richer in content and context than any formal representation of them.[5]

Specielt tabet af kontekst anses for problematisk i forhold til den kliniske anvendelse af information:

The idea that information is something that can travel freely, independent of its medium, is highly problematic. (...) Medical information is essentially bound to the context of its production. [7]

Flere arbejder - fx. [6,7,9] - har påpeget, at kontekstuelle faktorer kan være afgørende for klinisk fortolkning. Udgangspunktet for denne anskuelse er baseret på kliniske eksempler, som fx. Greenhalgh's illustration af, hvordan kontekstuelle faktorer som alder og eksposition kan have betydning for fortolkning af klinisk information:

The shadow on the chest radiograph of a 19 year old student returning from an overland trip across India may be objectively identical to that of a 56 year old smoker who has never been out of Sweden. Both may have coughed up blood. But the radiologist who looks at the $x$ ray films "sees" tuberculosis in one and a high probability of cancer in the other.[9]

De således anførte eksempler illustrerer punktvis nogle kontekstuelle faktorers betydning for opsamling og anvendelse af klinisk information, omend de hverken afbilder bredden af kontekstuelle faktorer eller den faktiske betydning af kontekst i forhold til daglig klinisk arbejde. 



\section{Forskningsmål}

Som anført i indledningen eksisterer der en vision om ubegrænset interoperabilitet, hvor klinisk information i højt struktureret form kan udveksles på kryds og tværs og fortolkes, som om den var skabt lokalt. Med afsæt i denne vision bliver klinisk information vidtgående standardiseret og struktureret. Samtidigt har flere forskellige og uafhængige arbejder på baggrund af kliniske eksempler anført, at strukturering af klinisk information medfører et tab af kontekst, hvorved den kliniske anvendelighed mindskes.

Der opstår således et skisma: På den ene side bliver k linisk information i tiltagende grad underkastet strukturering med henblik på at gøre informationen interoperabel. På den anden side har den øgede strukturering som konsekvens, at informationens kontekstuelle indhold reduceres, og at man derved mindsker den kliniske anvendelighed og således reducerer interoperabiliteten.

Der foreligger imidlertid ingen samlet beskrivelse af, hvad det er for kontekstuel information, som tabes, eller hvad det reelt betyder for interoperabilitet og klinisk arbejde. Det var derfor relevant at undersøge, hvorvidt kontekstuel klinisk information faktisk kan have en reel betydning for interoperabilitet, og hvilke former for kontekstuel information, det i givet fald drejer sig om. Med dette formål blev der udført et litteraturstudie, som fokuserede på svigtende interoperabilitet i form af manglende genbrug af kliniske data, og belyste forskningsspørgsmålene:

- Hvorfor genbruges kliniske oplysninger ikke?

- I hvilke situationer spiller kontekstuelle forhold en rolle for (manglende) datagenbrug?

På grundlag af resultaterne fra dette litteraturstudie blev der efterfølgende iværksat et studie med henblik på at vurdere, hvad kontekstuel klinisk information betyder for klinisk arbejde og for visionen om ubegrænset interoperabilitet, og at vurdere mulighederne for at stille kontekstuel klinisk information til rådighed for klinisk arbejde - fx. gennem dedikeret strukturering af kontekstuel information. Dette mål blev konkretiseret i forskningsspørgsmålene:

- Hvilken betydning har kontekstuel klinisk information for dagligt klinisk arbejde?

- I hvilket omfang kan kontekstuel klinisk information operationaliseres med henblik på at understøtte klinisk ræsonnement?

Hvad kontekst, og dermed også kontekstuel klinisk information, er, kan anskues i to ganske forskellige perspektiver. De to perspektiver, som er udførligt beskrevet i afsnit 7.3.3, side 32, giver anledning til forskellige overvejelser i forhold til visionen om ubegrænset interoperabilitet og operationalisering af kontekstuel klinisk information, og forskningsspørgsmålene er derfor belyst gennem to empiriske delstudier - ét delstudie i hvert perspektiv. 


\subsection{Afgrænsning}

Der er i det samlede studie foretaget en række overordnede valg og afgrænsninger:

\section{Det klinisk-lægefaglige perspektiv}

Et aspekt af visionen om ubegrænset interoperabilitet er, at klinisk information skal kunne genbruges i ikke-kliniske sammenhænge - afregning, statistik, forskning, etc. Klinisk informations primære formål er imidlertid at danne baggrund for klinisk arbejde, og der er derfor i dette studie anlagt et klart klinisk perspektiv. Studiet forholder sig således udelukkende til klinisk anvendelse af klinisk information.

Lægefaglig virksomhed udgør kerneydelsen i omfattende dele af sundhedsvæsenet, og manglende interoperabilitet $\mathrm{i}$ forhold til lægers adgang til oplysninger må derfor antages at have betydelig konsekvens. Uagtet at alle slags sundhedsarbejdere kan have behov for at anskue kliniske oplysninger i kontekst, vedrører dette studie derfor specifikt lægers tilgang til kontekstuelle oplysninger, og informationens relevans, anvendelighed og struktur er således konsekvent anskuet fra lægers synsvinkel.

Forskningsspørgsmålene for de to empiriske delstudier kan følgeligt præciseres:

- Hvilken betydning har kontekstuel klinisk information for lægers daglige kliniske arbejde?

- I hvilket omfang kan kontekstuel klinisk information operationaliseres med henblik på at understøtte lægers kliniske ræsonnement?

En konsekvens af det klinisk-lægefaglige perspektiv er, at klinisk information i dette studie opfattes og afgrænses på baggrund af dens lægefaglige anvendelse. Dette kommer særligt til udtryk i beskri velsen af journalen og dens indhold af kliniske oplysninger, afsnit 7.1, side 21, samt i behandlingen af kontekst i journalen og lægers kontekstualisering i slutningen af afsnit 7.3, side $35 \mathrm{ff}$.

\section{At operationalisere information}

At operationalisere tilgang til information dækker en bred vifte af virkemidler, som både omfatter logistik og præsentation, herunder også fx. brugerfladedesign, navigation og optimering af søgealgoritmer. Det er ikke sigtet med dette studie, som behandler operationalisering af information - dvs. strukturering af information på en måde, som gør det muligt at skabe operationel funktionalitet.

\section{Opfattelsen af kontekst}

Kontekst kan opfattes både i et deterministisk og et non-deterministisk perspektiv, jf. afsnit 7.3, side 29. Den deterministiske opfattelse (senere benævnt Dey's perspektiv) af kontekstuel klinisk information er vidt udbredt og har i betydelig grad været bestemmende for en sundhedsinformatiske udvikling med det erklærede mål, at kunne levere rette oplysninger i rette tid på rette sted. En konsekvens af determinismen er imidlertid, at anvendelsesområdet for kontekstuel information anskuet 
i dette perspektiv er begrænset til kliniske situationer, som er så veldefinerede, at de kan danne grundlag for forudsigelse. Dette i modsætning til den non-deterministiske opfattelse (senere benævnt Dourish's perspektiv) af kontekstuel klinisk information, hvis anvendelsesområde ikke har de samme begrænsninger, og som måske derved i højere grad kan anpasses den variabilitet og uforudsigelighed, der præger praktisk klinisk arbejde.

De to forskellige opfattelser af kontekst giver anledning til ganske forskellige overvejelser i forhold til visionen om ubegrænset interoperabilitet og operationalisering af kontekstuel klinisk information, og begge perspektiver er derfor lagt til grund for de udførte feltstudier og analyser.

\subsection{Studiets design}

Ganske tidligt i studiet blev det åbenlyst, at besvarelse af forskningsspørgsmålene kræver en eksplicit afgrænsning og præcisering af termer og begreber, som optræder i det sundhedsinformatiske domæne. Begrebsarbejde, herunder beskrivelse af analyse- og forståelsesrammer, har derfor en fremtrædende plads i denne afhandling.

I særlig grad har kontekst vist sig at være en vanskeligt afgrænsbar størrelse, og begrebsarbejdet har gjort det klart, at kontekst - og dermed også kontekstuel klinisk information - kan anskues i to meget forskellige perspektiver. Studiets forskningsspørgsmål har forskellig mening i de to perspektiver, og der er derfor foretaget to empiriske undersøgelser af lægers omgang med kontekstuel klinisk information - én undersøgelse i hvert kontekstperspektiv.

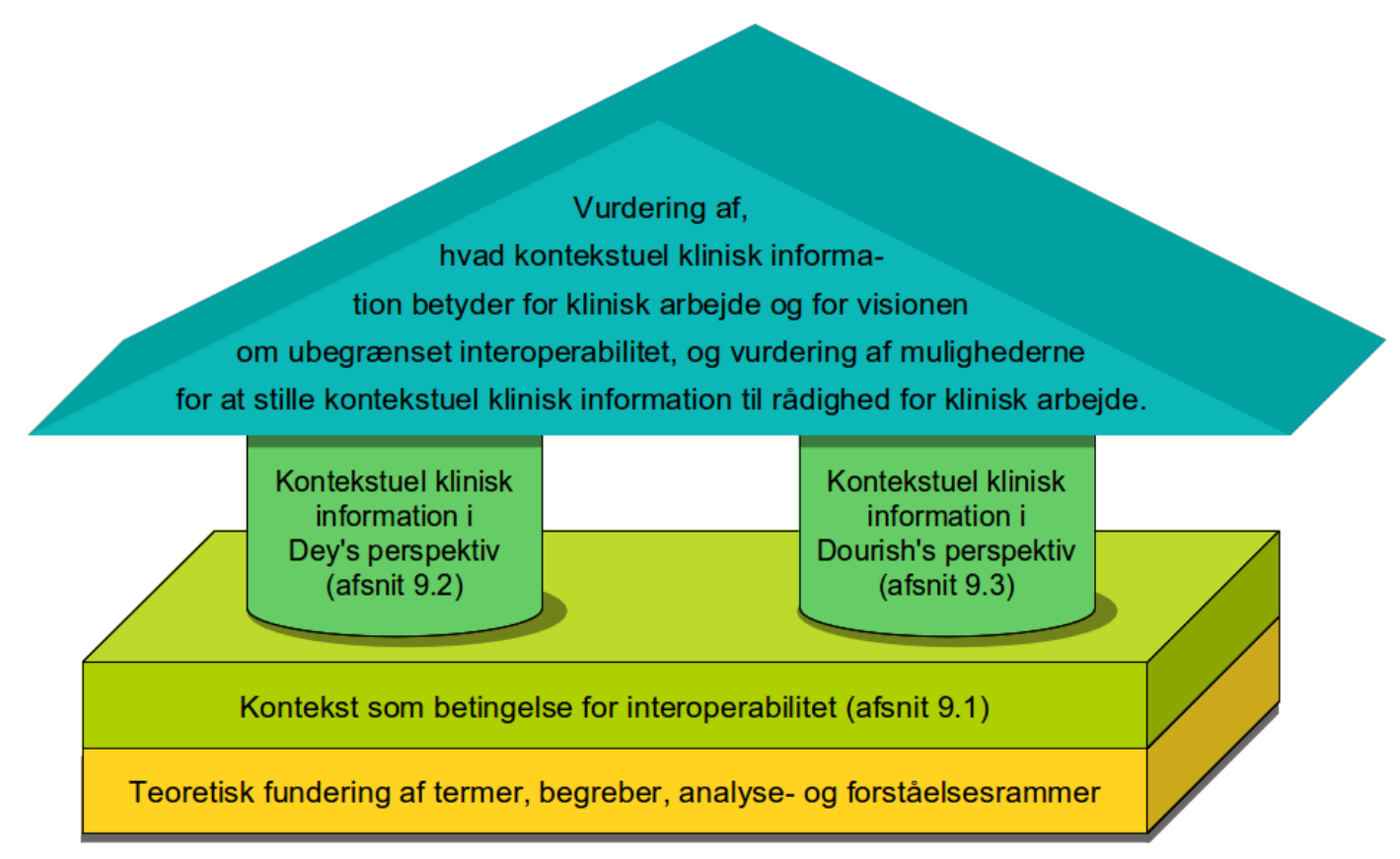

Figur 1. Studiets design 
Denne afhandling hviler således på et teoretisk fundament, et litteraturstudie og to empiriske undersøgelser, som det er illustreret på Figur 1.

Den tilgrundliggende forskning har gjort det muligt at vidensdisseminere og -dokumentere dele af studiet i form af fire peer-reviewed konferencepublikationer. Disse er vedlagt i bilag, henholdsvis:

- Bilag 1: How to Distinguish Double Documentation from Documentation of Distinct Data ([10])

- Bilag 2: Why Is Clinical Information Not Reused? ([11])

- Bilag 3: Production-Contextual Clinical Information ([12])

- Bilag 3: Contextualisation of Clinical Information from Fragmented Health Records ([13]) 


\section{Begreber, analyse- og forståelsesrammer}

Dette kapitel indeholder studiets teoretiske fundering, dels i form af præcisering og afgrænsning af centrale begreber, dels i form af analyse- og forståelsesrammer, som har været nødvendige for at kunne besvare forskningsspørgsmålene.

Det nedenstående afsnit 7.1 beskriver med reference til litteraturen basale begreber som 'kliniske oplysninger' og 'journal' og gør rede for, hvad journalen betyder for læger, hvordan den er struktureret og hvorfor der til stadighed udvikles digital journal. Afsnittet sammenstiller - baseret på eksisterende standarder - en ontologi for kliniske oplysninger med en opfattelse af sundhedsaktivitet til en samlet analyseramme for relationen mellem sundhedsaktiviteter og kliniske oplysninger.

Afsnit 7.2, side 26, beskriver interoperabilitet set i et sundhedsinformatisk perspektiv. På baggrund af en række beskrivelser af interoperabilitet gøres der rede for de forskellige grader af interoperabilitet med henblik på at kunne perspektivere visionen om ubegrænset interoperabilitet og gøre det klart, hvad det kræver at realisere denne vision.

Afsnit 7.3, side 29, beskriver med reference til litteraturen kontekst og de deraf afledte begreber. Der gøres i afsnittet rede for forskellige opfattelser af kontekst, herunder i særlig grad for de to opfattelser af kontekst (Dey's og Dourish's perspektiver), som i indeværende studie er blevet anvendt til fortolkning af kontekst-begrebet. De to kontekstperspektiver bliver sat i relation til hinanden og danner sammen grundlaget for beskrivelsen af en pragmatisk kontekstforståelse. I afsnittet beskrives kontekst både i forhold til udveksling og anvendelse af kontekstuel information, idet der lægges særlig vægt på at beskrive lægers kontekstualisering af kliniske oplysninger og anvendelsen af kontekstuel information i forbindelse med lægers indbyrdes kommunikation.

\subsection{Journalen og de kliniske oplysninger}

For at kunne behandle lægers omgang med kliniske oplysninger er det nødvendigt at etablere en konsistent forståelse af, hvad der forstås ved klinisk information, og hvordan lægernes centrale informatiske værktøj - journalen - fungerer.

Gennem århundreder har læger ført optegnelser om deres patienter. Optegnelsernes udformning har undervejs undergået betydelig forandring betinget af medicinsk, teknologisk og organisatorisk udvikling, der har ført til den kilde- og tidsorienterede, papirbaserede journal, som i dag er vidt udbredt[14]. 
Denne udvikling har flyttet formålet med optegnelser om patienten fra at være et simpelt personligt arbejdsredskab for den enkelte læge til at være en central informatisk komponent $\mathrm{i}$ en kompleks organisation. En konsekvens heraf er, at der stilles helt andre krav til optegnelsernes forståelighed. Som udtrykt af Ingenerf[6]:

There is a shift from the problem of "intrapersonal re-interpretability along time" to the even more difficult problem of "interpersonal re-interpretability along space"

Således skal den nutidige journal tilfredsstille en lang række aktørers ganske forskellige behov for at tilgå oplysninger[14]. Journalen skal:

- understøtte behandling og pleje, herunder ...

○ udgøre grundlag for klinisk vurdering og beslutning

$\circ$ tjene til løbende opsamling af information som deles mellem sundhedsarbejdere

- understøtte medikolegal vurdering

- understøtte klinisk og epidemiologisk forskning og uddannelse

- understøtte kvalitetsudvikling, herunder registrering af utilsigtede hændelser

- understøtte afregning og sundhedsstatistik

Journalen (i den forståelse af begrebet, som er beskrevet i termlisten, side 93) udgør sundhedsarbejdernes centrale informatiske værktøj[15,16] og er fødestedet for væsentlige dele af de oplysninger, som over tid samles om en patient. Der er således ikke blot tale om lægers optegnelser, men om nogle meget forskelligartede oplysninger.

De oplysninger, som opsamles i journalen, har det til fælles, at de er af relevans for patientens helbred, behandling eller pleje[7,17]. Disse oplysninger betegnes i denne afhandling - i overensstemmelse med 13606-standarden[18] - med de synonyme termer 'kliniske oplysninger' og 'klinisk information'.

I takt med udviklingen af elektronisk databehandling har der været en stigende interesse for at digitalisere kliniske oplysninger, og de sidste godt 40 år har fremvist multiple forsøg på at etablere en brugbar digital journal[14]. Denne vedvarende interesse for at udvikle digitale journaler er affødt af de potentielle fordele ved digitaliserede kliniske oplysninger, bla. at man i modsætning til papirbaserede journaler kan[14,19]:

- tilgå oplysningerne flere steder samtidigt

- genanvende information og således undgå dobbeltregistrering

- finde oplysninger hurtigt og udtømmende vha. digitale søge-algoritmer

- foretage søgning og aggregering på tværs af patienter 
- få multimedie-præsentation af kliniske oplysninger

- få beslutningsstøtte, spændende fra simple alarmer og notifikationer til avanceret interaktiv hjælp til diagnostik, behandlingsvalg, logistik, mm.

Betingelsen for at kunne realisere alle disse fordele er, at informationssystemerne meningsfuldt kan fortolke og behandle oplysningerne, og dette er årsagen til de sidste årtiers bestræbelser på at strukturere den kliniske information ved hjælp af modeller (fx. HL7, openEHR, HISA- og 13606-standarder) og terminologier (fx. ICD, SNOMED-CT, UMLS).

\subsubsection{Journalens overordnede struktur}

Van Bemmel og Musen[14] angav for godt 15 år siden, at den kilde- og tidsorienterede journal var vidt udbredt. Dette er formodentlig stadig tilfældet, selvom dele af journalen mange steder er digitaliseret - dedikerede kildeorienterede systemer (laboratorie, røntgen, mikrobiologi, etc.) leverer oplysninger digitalt eller på papir, og oplysningerne samles kildeorienteret i journalen.

I Region Hovedstaden, hvor denne afhandlings feltstudier er foretaget, anvendes en journal, der er beskrevet som kildeorienteret og fragmenteret, og hvor oplysninger både findes digitalt og papirbaseret[17].

Siden 2004 har man i regionen arbejdet på at udvikle journalen til brugernes behov - dels gennem udvikling af generaliserede kliniske informationsstrukturer (fx. standardplan, standardresultat)[20], dels gennem dedikerede funktionelle strukturer (fx. vitale værdier, ernæringsscreening)[21,22]. I skrivende stund har dette arbejde dog kun i meget begrænset omfang resulteret i implementeret sundheds-it.

\subsubsection{Forskellige slags kliniske oplysninger}

OpenEHR - en non-profit organisation, der udvikler standarder for lagring og udveksling af sundhedsdata - har som en del af deres udviklingsarbejde beskrevet en ontologi for klinisk information[23,24], der i denne afhandling benyttes som analyseramme. Ontologien omhandler registreret klinisk information, men den kan lige så vel appliceres på ikke-dokumenterede oplysninger, fx. anvendelse af klinisk information i konversation og konference. Ontologiens topniveau er begrebet 'Entry', som openEHR beskriver således:

An Entry is logically a single 'clinical statement', and may be a single short narrative phrase, but may also contain a significant amount of data, e.g. an entire microbiology result, a psychiatric examination note, a complex medication order.[23]

Denne ikke ret klare definition opfattes her som, at Entry er en klinisk oplysning formuleret som et logisk afgrænset udsagn. 
De forskellige typer klinisk information fremgår (uoversat) af Tabel 1 :

Tabel 1. Forskellige slags klinisk information (fra [24])

\begin{tabular}{|c|c|}
\hline Overordnet informationstype & $\begin{array}{l}\text { Underordnede } \\
\text { typer }\end{array}$ \\
\hline $\begin{array}{l}\text { Observation } \\
\text { information created by an act of observation, measure- } \\
\text { ment, questioning, or testing of the patient or related sub- } \\
\text { stance, in short, the entire stream of information captured } \\
\text { by the investigator, used to characterise the patient system. }\end{array}$ & \\
\hline $\begin{array}{l}\text { Action } \\
\text { a record of intervention actions that have occurred, due to } \\
\text { instructions or otherwise. }\end{array}$ & \\
\hline $\begin{array}{l}\text { Opinion } \\
\text { inferences of the investigator using the personal and pub- } \\
\text { lished knowledge base about what the observations mean, } \\
\text { and what to do about them; includes all diagnoses, assess- } \\
\text { ments, plans, goals. }\end{array}$ & $\begin{array}{l}\text { Diagnosis } \\
\text { Risk } \\
\text { Prognosis } \\
\text { Scenario } \\
\text { Goal } \\
\text { Recommendation }\end{array}$ \\
\hline $\begin{array}{l}\text { Instruction } \\
\text { opinion-based instructions sufficiently detailed so as to be } \\
\text { directly executable by investigator agents, in order to ef- } \\
\text { fect a desired intervention. }\end{array}$ & $\begin{array}{l}\text { Investigation request } \\
\text { Intervention request }\end{array}$ \\
\hline
\end{tabular}

OpenEHR's ontologi for klinisk information ligger til grund for den forståelse af journalens indhold, som er beskrevet i næste afsnit.

\subsubsection{Forståelsesramme for klinisk information i journalen}

Denne afhandling opfatter journalens indhold på et grundlag opstået ved anvendelse af begreber fra to modeller - CONTSYS[25,26] og openEHR[23].

CONTSYS (System of concepts to support continuity of care)[25] er en CEN-standard fra 2007, der beskriver et system af begreber af relevans for pleje og behandling. Standarden bidrager i denne forbindelse med en definition af sundhedsaktivitet:

sundhedsaktivitet (oversat fra [25]: "health care activity")

aktivitet, som udføres for en patient med henblik på direkte eller indirekte at forbedre eller bevare dennes helbred

OpenEHR bidrager med den klassifikation af klinisk information, som blev omtalt i forrige afsnit. 
Sammen anvendes de her til en opfattelse af, hvordan journalens indhold fremkommer - dels anskuet funktionelt (Figur 2), dels anskuet over tid (Figur 3).

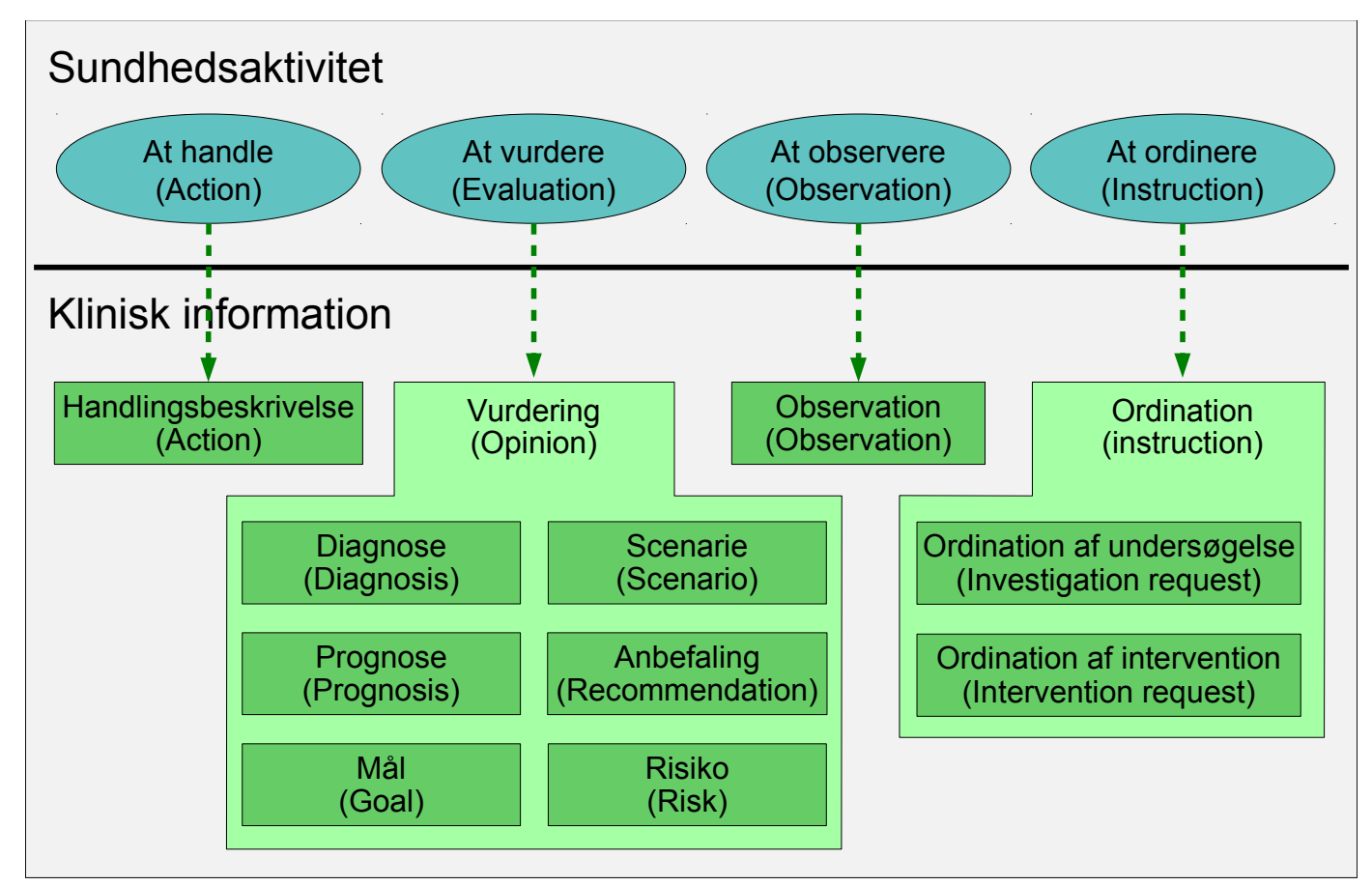

Figur 2. Fremkomsten af journalens indhold, anskuet funktionelt.

Figur 2 illustrerer en model af, hvordan journalens indhold fremkommer som resultatet af, at sundhedsarbejdere udfører sundhedsaktiviteter (handling, vurdering, observation, ordination) og dokumenterer disse aktiviteter som klinisk information i form af handlingsbeskrivelser, vurderinger, observationer og ordinationer.

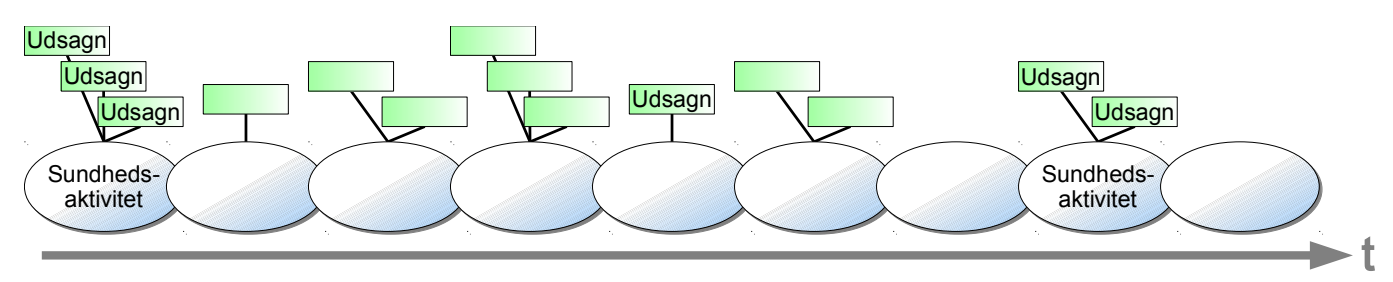

Figur 3. Fremkomsten af journalens indhold, anskuet over tid

Figur 3 illustrerer hvordan sundhedsaktivitet følger på sundhedsaktivitet, og hvordan den resulterende dokumentation udvikler sig over tid. Det skal her understreges, at figurens mængde af udsagn symboliserer hele journalens indhold - ikke blot de dele, der fysisk eller virtuelt fremvises i kronologisk orden.

Denne forståelsesramme for fremkomsten af klinisk information i journalen ligger til grund for afhandlingens opfattelse af dokumenteret kontekstuel information (illustreret i Figur 6, side 37) og for analyserne i Bispebjerg-studiet beskrevet i afsnit 8.2, side 50 . 


\subsection{Interoperabilitet}

Denne afhandling tager udgangspunkt $\mathrm{i}$ en problemstilling vedrørende strukturering af kliniske oplysninger. Den drivende kraft bag denne strukturering er dels et ønske om maskinelt at kunne behandle klinisk information - fx. smart søgning, beslutningsstøtte, mm. som anført i indledningen af forrige afsnit 7.1, side 21 - dels at kunne udveksle og genanvende klinisk information på tværs af systemer - at etablere interoperabilitet. Dette ønske om interoperabilitet har - som beskrevet i indledningen - over årtier udviklet sig til en omfattende og ambitiøs vision. Med henblik på at præcisere dybden og implikationerne af denne vision beskriver dette afsnit forskellige grader af interoperabilitet.

\subsubsection{Forskellige slags interoperabilitet}

Der foreligger fra flere domæner en række definitioner af interoperabilitet (se nedenstående Tabel 2), som tilsammen tegner et billede af, at informationssystemer kan anvende gensidigt udvekslet information, uden at dette kræver menneskelig indgriben.

Tabe1 2. Definitioner af interoperabilitet

\begin{tabular}{|l|l|}
\hline \multicolumn{1}{|c|}{ Interoperabilitet } & \multicolumn{1}{|c|}{ Kilde } \\
\hline $\begin{array}{l}\text { - the capability to communicate, execute pro- } \\
\text { grams, or transfer data among various func- } \\
\text { tional units in a manner that requires the user } \\
\text { to have little or no knowledge of the unique } \\
\text { characteristics of those units }\end{array}$ & $\begin{array}{l}\text { ISO/IEC 2382-1:1993, Information } \\
\text { technology - Vocabulary - } \\
\text { Fundamental terms. }\end{array}$ \\
\hline $\begin{array}{l}\text { - the ability of information and communica- } \\
\text { tion technology (ICT) systems and of the } \\
\text { business processes they support to exchange } \\
\text { data and to enable the sharing of information } \\
\text { and knowledge }\end{array}$ & $\begin{array}{l}\text { European Interoperability Framework } \\
\text { for Pan-European eGovernment } \\
\text { Services. European Communities, } \\
\text { 2004. }\end{array}$ \\
\hline $\begin{array}{l}\text { - the ability of multiple systems with different } \\
\text { hardware and software platforms, data struc- } \\
\text { tures, and interfaces to exchange data with } \\
\text { minimal loss of content and functionality }\end{array}$ & $\begin{array}{l}\text { Understanding Metadata. National } \\
\text { Information Standards Organization, } \\
\text { 2004. }\end{array}$ \\
\hline $\begin{array}{l}\text { - a state which exists between two application } \\
\text { entities when, with regard to a specific task, } \\
\text { one application entity can accept data from } \\
\text { the other and perform that task in an appropri- } \\
\text { ate and satisfactory manner without the need } \\
\text { for extra operator intervention }\end{array}$ & $\begin{array}{l}\text { Current and future standardization } \\
\text { issues in the eHealth domain: } \\
\text { CEN eHealth Standardization Focus } \\
\text { Group, 2005. }\end{array}$ \\
\hline
\end{tabular}


Systemer, som behandler klinisk information, udviser forskellige grader af interoperabilitet. Dette beskrives i SemanticHealth-rapporten som tre niveauer af interoperabilitet[4]:

Level 1: technical and syntactical interoperability (no semantic interoperability)

Level 2: uni- or bidirectional semantic interoperability of meaningful fragments

Level 3: full semantic interoperability, sharable context, seamless co-operability

hvor 'meaningful fragments' refererer til struktureret fremstilling af enkeltstående kliniske begreber - fx. demografiske data, allergier, diagnoser.

Til sammenligning med SemanticHealth-rapportens opfattelse af semantisk interoperabilitet definerer ISO 18308-standarden[27] to slags interoperabilitet som angivet i Tabel 3:

Tabel 3. Typer af interoperabilitet

\begin{tabular}{|c|l|}
\hline \multicolumn{1}{|c|}{ Definition } & Kilde \\
\hline $\begin{array}{c}\text { syntactic interoperability } \\
\text { capability of two or more systems to } \\
\text { communicate and exchange data through } \\
\text { specified data formats and communication } \\
\text { protocols }\end{array}$ & $\begin{array}{l}\text { ISO 18308:2011 Health informatics - } \\
\text { Requirements for an electronic health } \\
\text { remantic interoperability }\end{array}$ \\
$\begin{array}{l}\text { ability for data shared by systems to be } \\
\text { rnderstood at the level of fully defined } \\
\text { domain concepts }\end{array}$ & \\
\hline
\end{tabular}

Disse definitioner er i overensstemmelse med Asuncion et al.[28], der beskriver de samme typer af interoperabilitet således:

\section{syntaktisk interoperabilitet}

evnen til at udveksle information, som ved udvekslingen er struktureret på en kompatibel måde - typisk ved anvendelse af aftalte datastrukturer, koder og vokabularer

\section{semantisk interoperabilitet}

evnen til at udveksle information under bevarelse af de syntaktiske elementers betydning i forhold til genstande og fænomener

Asuncion et al. beskriver desuden en tredje type interoperabilitet[28]:

pragmatisk interoperabilitet

evnen til at udveksle information under bevarelse af den originale opfattelse af informationens vægt og implikationer 
og anfører en indbyrdes afhængighed mellem de forskellige typer:

- pragmatisk interoperabilitet kræver

- semantisk interoperabilitet kræver

- syntaktisk interoperabilitet.

De tre typer interoperabilitet kan således betragtes som en niveaudeling af interoperabilitet, der nøje modsvarer den graduering, som er beskrevet i SemanticHealth-rapporten. Blot svarer SemanticHealth-rapportens "full semantic interoperability, shareable context, seamless co-operability" til det, som Asuncion\&vanSinderen benævner 'pragmatisk interoperabilitet'.

Det skal bemærkes, at i flere arbejder er interoperabilitet - herunder semantisk interoperabilitet - beskrevet på en måde, hvor det pragmatiske aspekt tilsyneladende ikke er erkendt - fx. [29-32]. Der er dog også flere eksempler på, at det pragmatiske aspekt er erkendt, men betragtes som en del af semantisk interoperabilitet - fx. [4,33].

Anskuet under ét tegner der sig et billede af, at interoperabilitet kan optræde i tre kvaliteter/typer/grader:

syntaktisk interoperabilitet

hvor information kan udveksles uden tab eller forvanskning, men også uden sikkerhed for, at informationen forstås og fortolkes korrekt

semantisk interoperabilitet

hvor der desuden sker korrekt fortolkning og forståelse af informationens referencer til genstande og fænomener

pragmatisk interoperabilitet

hvor der desuden sker bevarelse af den originale opfattelse af informationens vægt og implikationer

\subsubsection{Visionen om ubegrænset pragmatisk interoperabilitet}

På side 14 i afsnit 5.1 er citeret SemanticHealth-rapportens beskrivelse af visionen om interoperabilitet. Den omfatter, at klinisk information efter at være udvekslet på tværs af sproglige, organisatoriske, juridiske og kulturelle grænser, direkte kan forstås og anvendes, som om informationen var skabt lokalt.

På grundlag af navnet kunne man forledes til at tro, at SemanticHealth-rapporten beskriver semantisk interoperabilitet. Anskuet i forhold til de ovenfor nævnte grader af interoperabilitet er det imidlertid åbenlyst, at det, som SemanticHealth-rapporten beskriver, er ubegrænset pragmatisk interoperabilitet. 


\subsection{Kontekst og kontekstuel information}

Kontekst er et mangetydigt begreb, og da det er helt centralt for denne afhandling, følger nedenstående en beskrivelse af den kontekst-forståelse, som danner grundlag for afhandlingen.

Der foreligger forskellige syn på og derfor forskellige definitioner af kontekst. I forhold til udveksling og behandling af klinisk information er det relevant at anskue kontekst både i et lingvistisk og et datalogisk perspektiv. I Tabel 5 er anført en række definitioner med disse perspektiver:

Tabel 4. Definitioner af kontekst

\begin{tabular}{|l|l|}
\hline \multicolumn{1}{|c|}{ Kontekst } & \multicolumn{1}{c|}{ Kilde } \\
\hline $\begin{array}{l}\text { - the whole structure of a connected passage } \\
\text { regarded in its bearing upon any of the parts } \\
\text { which constitute it; the parts which immedi- } \\
\text { ately precede or follow any particular passage } \\
\text { or 'text' and determine its meaning }\end{array}$ & $\begin{array}{l}\text { Oxford English Dictionary } \\
\text { http://www. oed.com/ }\end{array}$ \\
\hline $\begin{array}{l}\text { - the interrelated conditions in which } \\
\text { something exists or occurs }\end{array}$ & $\begin{array}{l}\text { Merriam-Webster Online Dictionary } \\
\text { http://www.m-w.com }\end{array}$ \\
\hline $\begin{array}{l}\text { - what constrains problem solving without in- } \\
\text { tervening in it explicitly }\end{array}$ & $\begin{array}{l}\text { Context in problem solving: a survey. } \\
\text { Brezillon, 1999. }\end{array}$ \\
\hline $\begin{array}{l}\text { - text which illustrates a concept or the use of } \\
\text { a designation }\end{array}$ & $\begin{array}{l}\text { ISO 1087-1:2000,Terminology work } \\
\text { - Vocabulary - Part 1: Theory and } \\
\text { application. }\end{array}$ \\
\hline $\begin{array}{l}\text { - any information that can be used to charac- } \\
\text { terize the situation of an entity. An entity is a } \\
\text { person, place, or object that is considered rel- } \\
\text { evant to the interaction between a user and an } \\
\text { application, including the user and applica- } \\
\text { tions themselves. }\end{array}$ & $\begin{array}{l}\text { Towards a Better Understanding of } \\
\text { Context and Context-Awareness. Dey } \\
\text { \& Abowd, 2000. }\end{array}$ \\
\hline $\begin{array}{l}\text { - related conditions and situations that } \\
\text { provide a useful understanding and meaning } \\
\text { of a subject }\end{array}$ & $\begin{array}{l}\text { ISO/TR 17119:2005, Health } \\
\text { informatics - Health informatics } \\
\text { profiling framework. }\end{array}$ \\
\hline
\end{tabular}

Som grundlæggende terminologisk udgangspunkt for denne afhandlings behandling af kontekst anvendes en definition, der er baseret på de ovenstående definitioner fra Merriam-Webster og ISO/TR 17119:

\section{$\underline{\text { kontekst }}$}

forhold og situationer som bidrager til meningsfuld forståelse af et givet emne

I modsætning til nogle af de ovennævnte definitioner - fx. ISO 1087-standarden[34] og Dey's arbejder[35,36] - bliver der i denne afhandling sondret mellem kontekst og kontekstuel information: 


\section{kontekstuel information}

information, som beskriver kontekst

Dette fordi afhandlingens fokus er mulighederne for at formidle kontekst ved hjælp af it-systemer, hvilket grundlæggende kræver, at konteksten er udtrykt som (behandlelig) information - et formkrav som selvsagt ikke tilfredsstilles af alle forhold og situationer.

\subsubsection{Kontekst i udveksling og kommunikation}

Den fremherskende strategi for at kunne udveksle og behandle klinisk information (inkl. dens kontekstuelle indhold) er - og har i årevis været - strukturering af informationen ved hjælp af modeller og terminologier[4].

I de mange tiltag for at strukturere klinisk information har man stedse opfattet kontekstuel information som integreret med, hvad man kunne kalde 'den kliniske kerneinformation' - fx. diagnoser, resultater, beskrivelse af interventioner. Et typisk eksempel er vist i nedenstående Figur 4:

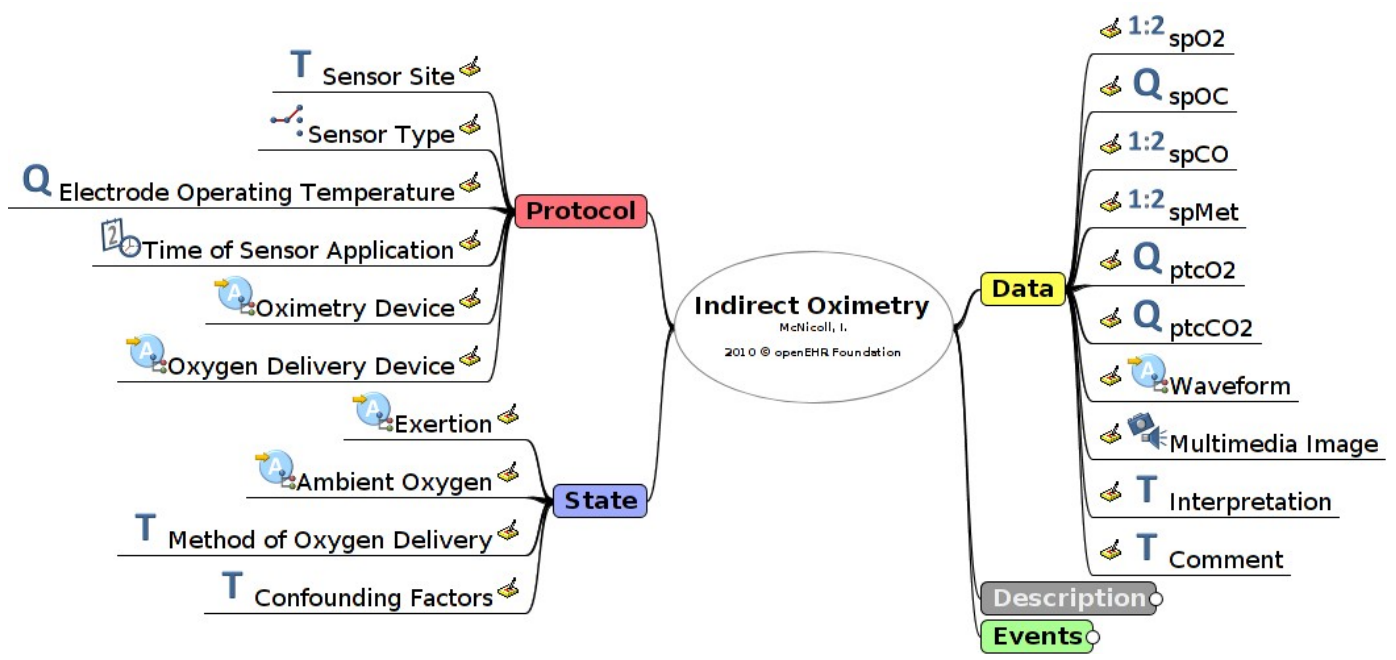

Figur 4. OpenEHR-arketype (pulsoxymetri). Bemærk de betydelige mængder kontekstuel information i Protocol- og State-grenene.

Der har i det sundhedsinformatiske domæne kun i meget begrænset omfang været gjort forsøg med generisk modellering af kontekst. Bricon-Souf et al.[37] har i 2007 foretaget et review af studier med context-aware computing indenfor sundheds-it, og skriver:

No organization of context is used even if recommended in the more fundamental studies of context awareness ... Developing context-aware applications is not a problem of access to technologies (sensors, networks, etc.) as these exist. One difficulty is, as yet, the research community has not reached a consensus as to the best way to model context and architectures to support its use.[37] 
Samme synspunkt er - på et mere generaliseret niveau - fremført af Winograd[38], der om strukturering af kontekst skriver:

The hard part of this design will be the conceptual structure, not the encoding. Once we understand what needs to be encoded, it is relatively straightforward to put it into data structures, data bases, and so forth. The hard part will be coming up with conceptual structures that are broad enough to handle all of the different kinds of context, sophisticated enough to make the needed distinctions, and simple enough to provide a practical base for programming.[38]

I forhold til kommunikation er kontekst af flere beskrevet som en essentiel del af kommunikation, både $\mathrm{i}$ et generelt perspektiv[28,38,39] og i et sundhedsinformatisk perspektiv[4,6,7,40]. Kontekst beskrives som en forudsætning for den korrekte fortolkning og opfattelse af meddelelser, og flere af de anførte arbejder - fx. [6,28] - beskriver kontekst som en forudsætning for pragmatisk interoperabilitet:

At the system level, pragmatic interoperability essentially means sharing the same understanding of the intended and actual use of exchanged system message in a given context.[28]

Det synes således at være en betingelse for etablering af visionen om ubegrænset pragmatisk interoperabilitet at de involverede informationssystemer kan udveksle og behandle kontekst.

\subsubsection{Kontekst $\mathrm{i}$ forhold til anvendelse af klinisk information}

Flere arbejder rejst kritik af sundheds-it's evne til på hensigtsmæssig måde at understøtte brugernes behov. Af særlig relevans for denne afhandling er, at der er rejst kritik af informationssystemernes manglende evne til at udveksle og behandle kontekst. Således har fx. Rector påpeget, at man ikke indenfor overskuelig tid kan forvente at struktureret information kan komme på højde med naturligt sprog med hensyn til at udtrykke indhold og kontekst[5], og Berg har i flere arbejder, fx. [7,8,41] anført, at den strukturerede information ikke retvisende "afbilder patienten":

The list of coded complaints, pressures, examination results and so forth was very useful to track some overall parameters - yet it could not capture that the core reason of the patient's visit was his increased anxiety about his hypertension, for example, triggered by the recent death of his father.[41]

Det tilgrundliggende problem synes at være, at man ved at strukturere de kliniske oplysninger mister kontekstuel information, som er nødvendig for den kliniske anvendelse af oplysningerne:

The idea that information is something that can travel freely, independent of its medium, is highly problematic. (...) Medical information is essentially bound to the context of its production. [7] 
Argumentationen for, at kontekstuel information er vigtig for anvendelsen af kliniske oplysninger, er ført - fx. af Berg[7,41] og Ingenerf[6] - gennem ekstrapolation af eksempler. Der synes ikke at være foretaget undersøgelser for at afdække, hvad kontekstuel information reelt betyder for dagligt klinisk arbejde.

\subsubsection{Forskellige opfattelser af kontekst(uel information)}

Indenfor sundhedsinformatik har kontekst som begreb ikke fået megen opmærksomhed. Det er derimod blevet udførligt behandlet i sammenhæng med context-aware computing, ubiquitous computing og human-computer-interaction, hvor målet er at lade it-systemers funktionalitet modulere af den kontekst, hvori system og bruger befinder sig. Både Dey[36] og Zimmermann[42] beskriver begge i forbindelse med context-aware computing og med udgangspunkt i Dey's definition af kontekst(uel information) (se Tabel 4, side 29) - en emnebaseret opdeling, hvor de primære typer af kontekstuel information vedrører:

- sted (location)

- identitet

- tid

- aktivitet

- relationer mellem identiteter

og hvor sekundære typer anskues som relative til disse - fx. identitet $=>$ e-mailadresse. Zimmermann beskriver således kontekstuel information som et 5-dimensionalt udfaldsrum.

Dey og Zimmermann illustrerer et paradigme, hvor kontekst opfattes som fikseret og deterministisk. I modsætning hertil beskriver Winograd[38] og Dourish[43] et paradigme, hvor kontekst opfattes som variabelt og situationelt. Winograd udtrykker, at kontekst er en rolle, som noget kan optræde i:

Something is context because of the way it is used in interpretation, not due to its inherent properties[38].

og Dourish beskriver mere indgående de to paradigmer:

Tabel 5. Kontekst anskuet i to perspektiver (efter Dourish[43])

\begin{tabular}{|l|l|l|}
\hline $\begin{array}{l}\text { Typisk } \\
\text { eksponent: }\end{array}$ & Dey[36] & Dourish[43] \\
\hline $\begin{array}{l}\text { At opera- } \\
\text { tionalisere } \\
\text { kontekst: }\end{array}$ & - udgør et strukturelt problem & - udgør et interaktionelt problem \\
\hline
\end{tabular}




\begin{tabular}{|c|c|c|}
\hline $\begin{array}{l}\text { Overordnet } \\
\text { problem- } \\
\text { stilling: }\end{array}$ & $\begin{array}{l}\text { It-systemer er baseret på struktu- } \\
\text { rerede modeller af virkeligheden. } \\
\text { Hvordan strukturerer man kon- } \\
\text { tekst, så det kan behandles af it- } \\
\text { systemer? }\end{array}$ & $\begin{array}{l}\text { Kontekst opstår som en integreret } \\
\text { del af interaktionen mellem it- } \\
\text { system og bruger. Hvordan kan } \\
\text { systemet understøtte brugerens } \\
\text { muligheder for at erkende og ska- } \\
\text { be kontekst? }\end{array}$ \\
\hline \multirow{4}{*}{$\begin{array}{l}\text { Grundlæg- } \\
\text { gende an- } \\
\text { tagelser }\end{array}$} & $\begin{array}{l}\text { Kontekst er en slags information. } \\
\text { Det er noget, der kan udtrykkes } \\
\text { og behandles på samme måde } \\
\text { som al anden information. }\end{array}$ & $\begin{array}{l}\text { Noget kan ikke bare være kon- } \\
\text { tekst i sig selv; det kan være kon- } \\
\text { tekstuelt relevant i forhold til en } \\
\text { given situation. Kontekstualitet er } \\
\text { en relationel egenskab mellem ob- } \\
\text { jekter eller aktiviteter. }\end{array}$ \\
\hline & $\begin{array}{l}\text { Kontekst kan afgrænses. Man kan } \\
\text { for et givet system på forhånd ud- } \\
\text { sige, hvad der kan udgøre kon- } \\
\text { tekst for de aktiviteter, som ud- } \\
\text { spiller sig indenfor systemet. }\end{array}$ & $\begin{array}{l}\text { Omfanget og typerne af kontekst } \\
\text { kan ikke forudses, men bestem- } \\
\text { mes af aktøren i situationen. }\end{array}$ \\
\hline & $\begin{array}{l}\text { Kontekst er stabil. Forskellige sy- } \\
\text { stemer indebærer, at aktiviteter } \\
\text { udføres i forskellig kontekst, men } \\
\text { i et givet system udføres en given } \\
\text { aktivitet altid i samme, forudsige- } \\
\text { lige kontekst. }\end{array}$ & $\begin{array}{l}\text { Kontekst er situationel og derfor } \\
\text { enestående i forhold til enhver in- } \\
\text { stans i ethvert scenarie. }\end{array}$ \\
\hline & $\begin{array}{l}\text { Kontekst kan adskilles fra aktivi- } \\
\text { tet. Aktivitet foregår i en kontekst, } \\
\text { og er altså sekundær til denne. }\end{array}$ & $\begin{array}{l}\text { Kontekst opstår i kraft af og i for- } \\
\text { hold til aktivitet. Kontekst skabes, } \\
\text { formes og vedligeholdes gennem } \\
\text { aktiviteten. }\end{array}$ \\
\hline
\end{tabular}

Selvom disse to opfattelser af kontekst kan synes at være modstridende, bemærkes det, at begge er i overensstemmelse med den her valgte definition af kontekst ('forhold og situationer som bidrager til meningsfuld forståelse af et givet emne'). Frem for at se dem som konkurrerende, anskues de i denne afhandling som kompletterende indfaldsvinkler til at forstå kompleksiteten af kontekst.

Der vil i det efterfølgende blive refereret til de to perspektiver som henholdsvis Dey's og Dourish's perspektiv.

Anskuet i Dey's positivistiske perspektiv er der ingen forskel på kontekst og kontekstuel information, som i alt væsentligt er givet ved de omstændigheder, hvorunder entiteter interagerer. Kontekstuel information anskues derfor som beskrivelsen af disse omstændigheder. Kontekst er baseret på en ekstern vurdering af, hvad en aktør kan lægge til grund for meningsfuld forståelse af et givet emne. Kontekst kan med de rette modeller og værktøjer formuleres og udveksles. Kontekstens art og indhold kan - optimalt - forudsiges og gengives. 
Anskuet i Dourish's konstruktivistiske perspektiv bliver noget kontekst i kraft af, at en aktør i forbindelse med en aktivitet tillægger dette 'noget' rollen som kontekst (se også ovenstående citat af Winograd). Dette 'noget' kan være hvad som helst, som aktøren i situationen gør brug af i sin forståelse af det aktuelle emne. Kontekst er således opstået af aktørens (måske implicitte) opfattelse af, hvad er relevant $\mathrm{i}$ forhold til situation og emne.

Hvor kontekst i Dourish's perspektiv kun er begrænset af, hvad en aktør i situationen opfatter som relevant, har kontekst i Dey's perspektiv tydeligt færre frihedsgrader: det har en deterministisk afgrænsning og det er bundet til aktivitets-/situationstype. Det kan derfor under givne omstændighe der være muligt at opfatte kontekst i Dey's perspektiv som en delmængde af kontekst i Dourish's perspektiv.

Det skal her bemærkes, at SemanticHealth-rapporten[4] i forbindelse med sin beskrivelse af visionen om ubegrænset pragmatisk interoperabilitet anbefalede (yderligere) modellering og klassifikation med henblik på at kunne udtrykke og udveksle klinisk information - herunder også kontekstuelle oplysninger. Denne tilgang har som basal forudsætning, at det overhovedet er muligt eksplicit at udtrykke informationen - en forudsætning, som for så vidt angår kontekst, er baseret på Dey's perspektiv.

\subsubsection{En pragmatisk forståelse af kontekst}

Med udgangspunkt i de to ovennævnte teoretiske perspektiver kan man beskrive en opfattelse af kontekst, som erkender vanskeligheden ved struktureret fremstilling[37,38] og som samtidigt erkender at kontekst i nogen grad kan forudsiges. Denne mere pragmatiske forståelsesramme kan beskrives ved de følgende udsagn:

- Kontekst er forhold og situationer (reelle eller imaginære) som bidrager til meningsfuld forståelse af et givet emne.

- Kontekst er en rolle, som forhold og situationer kan optræde i.

- Rollen som kontekst tildeles af en aktør i en situation. Denne tildeling benævnes "kontekstualisering". At noget er (i rollen som) kontekst, er specifikt for denne aktør i denne situation.

- En aktør kan kontekstualisere forhold og situationer gennem deres beskrivelse eller gennem viden om dem. Sådan information benævnes her 'kontekstuel information'.

- Aktører kan i forhold til en konkret situation dele kontekst, hvorved forstås, at der er forhold og situationer, som de begge har kontekstualiseret.

- På grundlag af overvejelser om hyppighed kan det sandsynliggøres, at en given aktør i en given situation vil kontekstualisere bestemte forhold og situationer. 
Fremadrettet er det denne opfattelse af kontekst, som ligger til grund for de dele af afhandlingen, hvor der ikke eksplicit er angivet et kontekstperspektiv.

\subsubsection{Forståelsesramme for kontekstuel information i journalen}

Kommunikation er i dette studie anskuet med udgangspunkt i en simpel og til formålet fremstillet model (se Figur 5) inspireret af Schramm[44], hvor aktører kommunikerer ved at udveksle udsagn. Modellen er fremstillet med henblik på, at dele af den skal kunne symbolisere sundhedsarbejderes anvendelse af journalen. Den er derfor bevidst forsimplet til kun at afbilde kommunikation, som foregår indenfor en fælles overordnet referenceramme og kun mellem aktører enkeltvis.

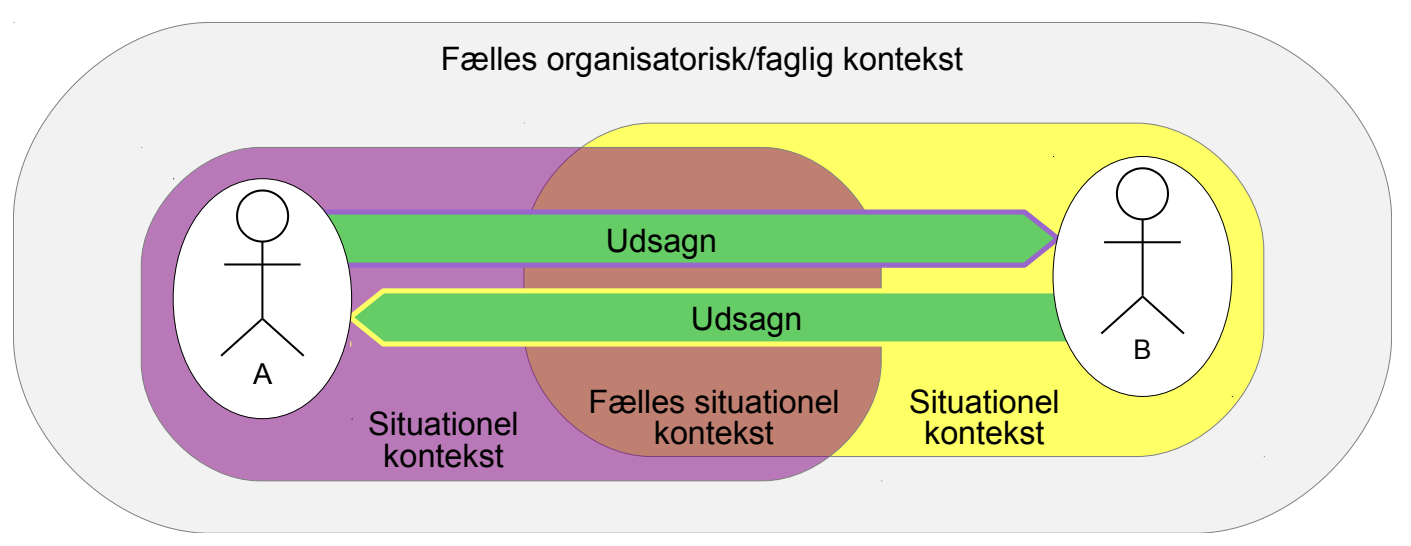

Figur 5. Kontekst i en simpel to-vejs kommunikationsmodel. Se forklaring nedenstående.

Figur 5 symboliserer, at to aktører kommunikerer ved at udveksle udsagn - det kunne fx. være to læger, som konfererer. Udsagnene kan, men behøver ikke nødvendigvis, indeholde kontekstuel information. For at aktørerne kan have en fælles, meningsfuld forståelse af udsagnenes indhold (læs: kan opnå pragmatisk interoperabilitet), er det nødvendigt at de deler kontekst[38,39,45,46]. Denne "deling af kontekst" skal opfattes som anført i ovenstående afsnit 7.3.4 dvs. at der er forhold og situationer, som begge aktører i situationen har kontekstualiseret. Eller som udtrykt af Schmidt \& Bannon:

In terms of their interpretation, the actors must attempt to jointly construct a common information space which goes beyond their individual personal information spaces. ... The common information space is negotiated and established by the actors involved.[47]

Når aktører - som det er tilfældet for sundhedsarbejdere - skal kunne udveksle kompleks information på en effektiv måde, kræver det en meget omfattende fælles kontekst[39,48]. Inspireret af eksempler fundet hos fx. Berg[7], Nelson[49] og Ingenerf[6] kan man beskrive to dele af den fælles kontekst, som er af særlig relevans for denne afhandling:

- organisatorisk/faglig kontekst, i betydningen: opfattelse af den organisatoriske og faglige virkelighed, hvori aktørerne befinder sig. Fx: 
○ hvordan hierarki og kommandoveje ser ud i den konkrete organisation

○ hvad de forskellige personalegrupper har fået tildelt af kompetencer og opgaver

○ hvad forskellen er på en en intensiv- og en genoptræningsafdeling

○ hvad "hoftealloplastik" er

○ hvordan "vi plejer at gøre her"

- situationel kontekst, som både omfatter opfattelse af den konkrete situation, hvori der kommunikeres, og opfattelse af emnet, som er genstand for kommunikationen. Fx:

○ vedrørende opfattelsen af den konkrete situation:

- hvor omfattende den anden aktørs erfaring og kvalifikationer er

- hvad formålet med og forventningerne til kommunikationen er

- hvad tid på døgnet og hvor kommunikationen foregår

○ vedrørende opfattelsen af emnet:

- om en undersøgelse er udført som rutine eller med et specifikt formål

- om en involveret aktør har den fornødne erfaring

- hvordan en undersøgelse/intervention er udført

- hvad patientens diagnose er og hvilken medicin patienten får

Den samlede kontekst giver aktørerne mulighed for at forstå udsagnenes indhold, formål og konsekvens i den aktuelle situation, og for at reagere adækvat.

Eksempe1 1. Organisatorisk/faglig og situationel kontekst

Et udsagn, hvor modtageren mangler den fornødne kontekst er ikke meningsfuldt, fx: "Lars Hansens blodtryk er på vej ned igen. Skal vi pausere med beta-blokker?"

For overhovedet at forstå spørgsmålets karakter kræves organisatorisk/faglig kontekst i form af sundhedsfaglig baggrundsviden om begreber som blodtryk og betablokker, om forskellige afdelingers opfattelse af faldende blodtryk, om forskellige personalegruppers kvalifikationer i forhold til at vurdere fysiologiske ændringer, om betydningen af faldende blodtryk for forskellige patientgrupper, etc.

Og for at forstå selve spørgsmålets indhold og formål er det nødvendigt med situationel kontekst. fx. er det ikke ligegyldigt om man er på en intensivafdeling, udsagnet er fra en yngre til en ældre læge, klokken er 02 og Lars Hansen er på dødens rand, eller man er på en kardiologisk afdeling, udsagnet er fra en sygeplejerske til en læge under ordinær stuegang, og Lars Hansens blodtryk bare har været lidt til den høje side.

I tidstro 1:1-kommunikation, fx. ved konference mellem to læger, er det muligt for aktørerne at interagere og give feed-back[44]. De kan kvittere for at udsagn er forstået, og de kan med udsagn uddybe den situationelle (og såmænd også den organisatorisk/faglige) kontekst. 
I forbindelse med dokumentation i journalen kan modellen fra Figur 5 ikke anvendes direkte. I modsætning til, hvad der er symboliseret i Figur 5, er kommunikation gennem journalen en ikketidstro envejs-kommunikation: Hver sundhedsaktør dokumenterer sine udsagn uden at vide, hvem der læser dem, hvornår de bliver læst, eller om de overhovedet bliver læst[7,29]. Udgangspunktet synes dog at være, at udsagn i journalen er afpasset til modtagere, som i væsentlig grad deler organisatorisk/faglig kontekst[17,46,50]. Anskuet i forhold til den ovenstående model, kan man således udtrykke anvendelse af journalen som afbildet i Figur 6 og Figur 7:

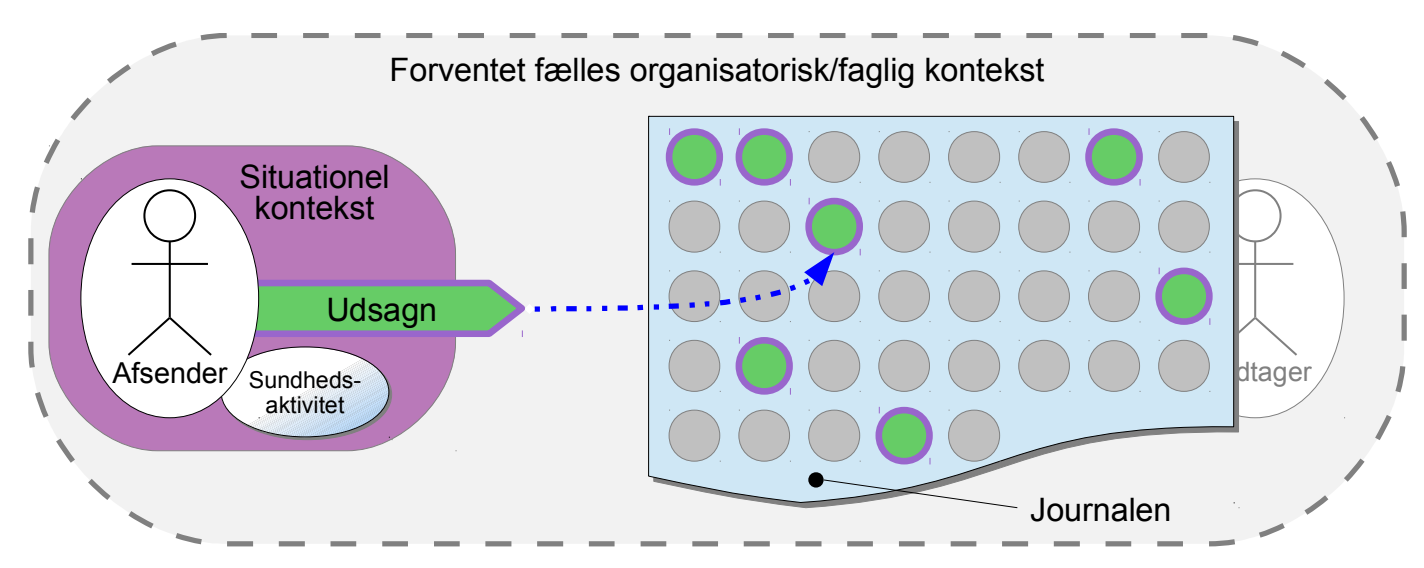

Figur 6. At "skrive" i journalen

Figur 6 symboliserer, at en sundhedsarbejder dokumenterer en sundhedsaktivitet (se evt. afsnit 7.1.3, side 25) ved at tilføje kliniske oplysninger i journalen, men uden at vide, hvilke aktører der vil modtage disse udsagn. Som en del af dokumentationen kan der være beskrivelse af Afsenders situationelle kontekst.

På samme måde symboliserer Figur 7, at en sundhedsarbejder henter kliniske oplysninger i journalen, herunder Afsenders beskrivelse af sin situationelle kontekst.

I begge tilfælde har aktørerne forventning om, at brugere af journalen i vid udstrækning kan dele organisatorisk faglig kontekst[46].

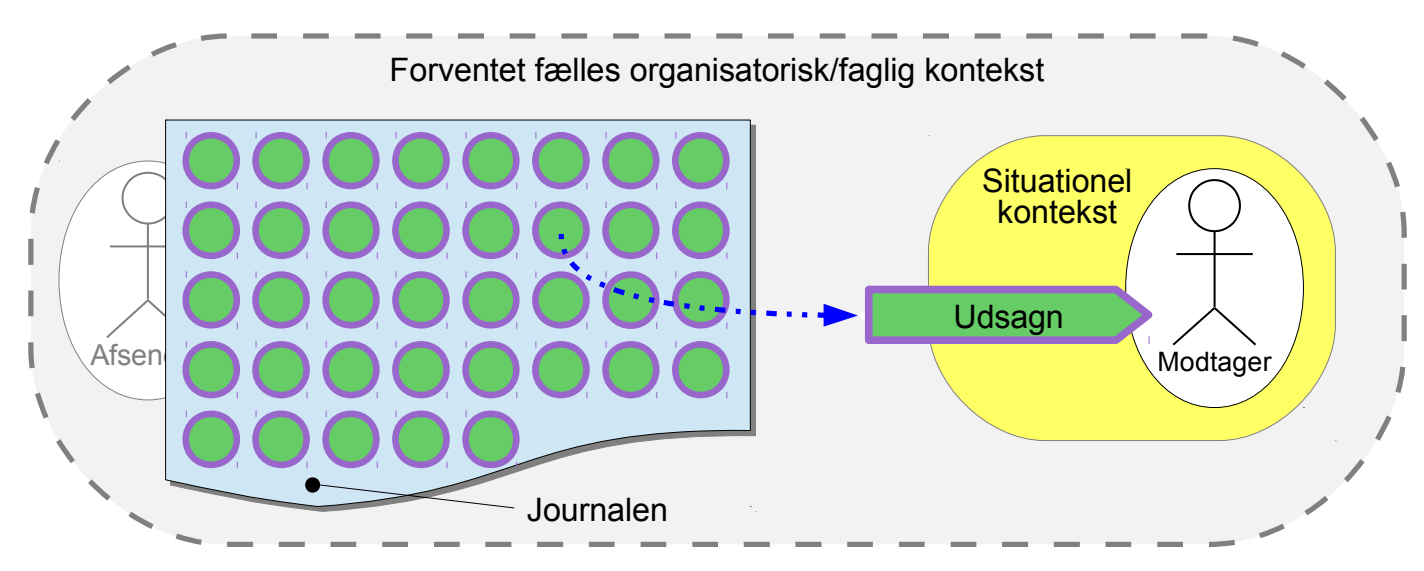

Figur 7. At "læse" i journalen 
For at sandsynliggøre at Modtager forstår udsagnet, kan Afsender supplere dokumentationen med kontekstuel information. Det kan dreje sig om information, som afsenderen har kontekstualiseret som en del af sin egen forståelse (fx. "Patienten klager over hovedpine. Det skyldes muligvis NTGbehandlingen."), men også om information, som afsenderen kontekstualiserer af hensyn til Modtagers forståelse (fx. "Cordarone seponeres. Dette efter konference med dr. X.").

Det bemærkes, at der med denne form for kommunikation ikke er mulighed for ad hoc at foretage supplerende deling af kontekst, og at den fælles situationelle kontekst derfor er begrænset af, hvad Afsender har tilføjet af kontekstuel information, og hvad Modtager kan ekstrapolere på grundlag af organisatorisk/faglig kontekst.

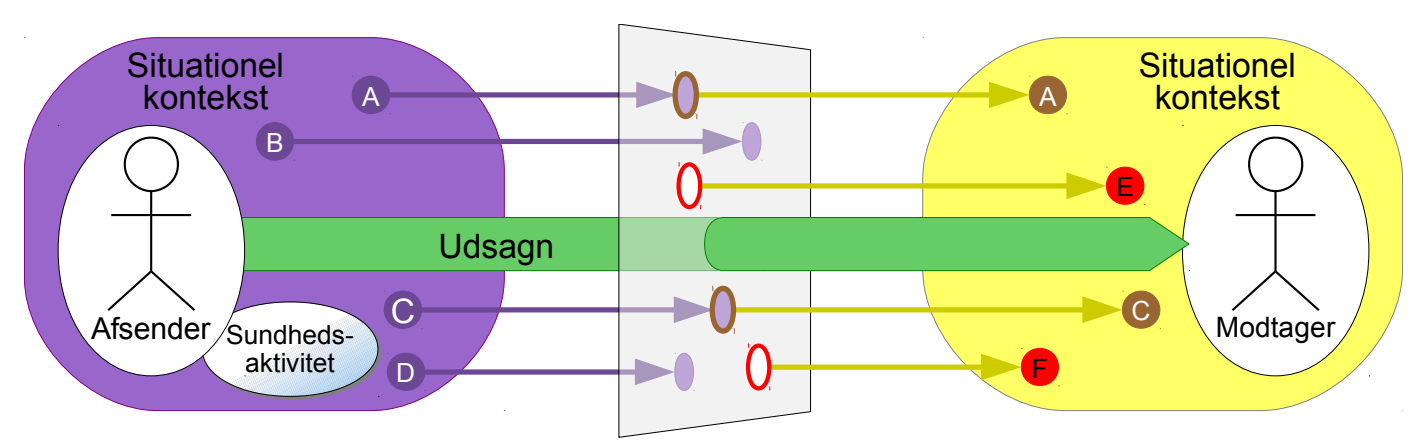

Figur 8. Afsender supplerer Udsagn med de kontekstuelle oplysninger A-D. Modtager vælger i situationen at kontekstualisere A \& C. Modtager kontekstualiserer desuden oplysningerne E \& F, som Afsender imidlertid ikke har dokumenteret.

Som illustreret i Figur 8 er det imidlertid ikke sådan, at alt, hvad Afsender dokumenterer, automatisk kommer til at indgå i fælles kontekst. Det er i forrige afsnit beskrevet, hvordan Modtager definerer sin egen kontekst, og det kan således hænde, både at Modtager ikke kontekstualiserer Afsenders kontekstuelle oplysninger, og at Modtager i relation til sundhedsaktiviteten kontekstualiserer oplysninger, som Afsender ikke har dokumenteret - og måske slet ikke har set som kontekst.

\subsubsection{Kontekstualisering som proces}

Adskillige arbejder, fx. [51-55], har beskrevet lægers kognitive processer - fortrinsvis de diagnosticerende og problemløsende. Specielt har Patel et al.[52,55,56] foretaget en række in-vitro-studier med beskrivelse af, hvorledes læger skaber (diagnostisk) mening på grundlag af kliniske oplysninger, eller - rettere - hvordan læger begrunder deres mening med støtte i givne oplysninger. Man har i disse arbejder været opmærksom på, at lægerne internt skaber og opretholder struktur i den kliniske information:

Developing a problem representation involves organizing knowledge into meaningful structures in memory. Such memory structures include the salient aspects of the information (e.g., gist, 
summary, major case characteristics) and the context needed for its interpretation (e.g., from memory of previous readings or patients seen).[55]

Imidlertid har disse arbejder ikke haft fokus på, hvordan læger tilegner sig den kliniske information, eller hvordan de i forbindelse med tilegnelsen strukturerer informationen, men på lægernes vægtning og strukturering af information, som den kommer til udtryk, når lægerne retrospektivt redegør for diagnostisk proces. Fokus har således været på lægernes ud-data fremfor på deres ind-data - på ræsonnementet fremfor på kontekstualiseringen.

Andre arbejder har fokuseret på lægers måde at behandle inddata. Flere arbejder har således påpeget, at måden hvorpå klinisk information præsenteres, er af betydning for tilegnelsen og (dermed) anvendelsen af information[46,57-59].

Patel et al. har $\mathrm{i}$ et arbejde med fokus på sammenhængen mellem sundheds-it og organisation vist, at den måde, hvorpå læger internt strukturerer deres information, påvirkes af den struktur, der er indbygget i de anvendte dokumentationsværktøjer[60]. Berg et al.[8] har udtrykt det således:

By providing a specific structure and context to the data accumulated, the record's form enhances the information content of these data. [8]

Kannampallil et al.[61] har på en intensivafdeling undersøgt, hvordan læger in-vivo indsamler og anvender klinisk information. Man interesserede sig i undersøgelsen for arten af kliniske oplysninger, hvilke journaldele de blev hentet fra, og hvor lang tid det tog. Man fandt, at lægernes måde at indhente information udgør en optimeret tilpasning til de lokale omstændigheder, og man anbefalede at kliniske informationssystemer i højere grad understøtter lægernes workflow og deres kognitive processer.

Men uanset om disse studier har fokuseret på lægers ind- eller uddata har de - i det omfang de har forsøgt at afbilde lægernes informationsstruktur[52,61] - anvendt (varianter af) samme skabelon: 'the medical knowledge framework '[52,55]:

Tabel 6. Klassifikation af klinisk information ('the medical knowledge framework') beskrevet af Arocha et al. [55]

\begin{tabular}{|c|c|}
\hline Niveau & Beskrivelse \\
\hline 1 & $\begin{array}{c}\text { empirium, which corresponds to the basic descriptions of sensory } \\
\text { data and carries no medical interpretation, such as anatomical } \\
\text { descriptions or skin color }\end{array}$ \\
\hline
\end{tabular}




\begin{tabular}{|c|c|}
\hline Niveau & Beskrivelse \\
\hline 2 & $\begin{array}{r}\text { observations, which are perceptual categories that serve as basis for } \\
\text { clinical classification, and therefore require medical knowledge } \\
\text { to identify and categorize. For instance, patterns of shade in a } \\
\text { radiological image or distinguishable heart sounds, which may } \\
\text { be imperceptible to an untrained eye or ear, are interpreted as } \\
\text { observations by a physician. }\end{array}$ \\
\hline 3 & $\begin{array}{r}\text { findings, clusters of observations that are interpreted in terms of } \\
\text { their clinical relevance, such as when shortness of breath, for } \\
\text { instance, is interpreted in the context of myocardial infarction. }\end{array}$ \\
\hline 4 & $\begin{array}{c}\text { facets, representing sub-diagnostic categories that suggest potential } \\
\text { diagnoses (e.g., cardiovascular) and discard some others (e.g., } \\
\text { pulmonary). }\end{array}$ \\
\hline 5 & $\begin{array}{c}\text { diagnoses, which are clinical categories with more or less known } \\
\text { explanatory and therapeutic models. }\end{array}$ \\
\hline 6 & $\begin{array}{c}\text { global complexes, which are the circumstances that affect a } \\
\text { particular patient, such as particular age groups or patient } \\
\text { characteristics that may influence a diagnosis or a management } \\
\text { path. }\end{array}$ \\
\hline
\end{tabular}

Denne skabelon, der i ovenstående Tabel 6 er gengivet efter Arocha et al. [55], klassificerer klinisk information i op til seks niveauer og er udviklet med henblik på at kunne forklare lægers diagnostiske ræsonnement. Der er således ikke tale om at afbilde lægers faktiske informationsstruktur, men om at projicere deres kontekstualiserede information ind i en teoretisk referenceramme til forklaring af diagnostisk proces.

Hvor en række arbejder[8,60,61] påviser, at lægers kontekstualisering er påvirket af journalens struktur, er den klinisk-logiske informationsstruktur, som læger skaber i takt med at de situationelt kontekstualiserer kliniske oplysninger, tilsyneladende ikke undersøgt. 


\section{Delstudierne}

I kapitel 6, side 17, er beskrevet, hvordan det samlede studie er designet med delstudier i to faser: Først et litteraturstudie med henblik på at undersøge, hvorvidt kontekstuel klinisk information reelt kan kan være af betydning for interoperabilitet og hvilke former for kontekstuel information det $\mathrm{i}$ givet fald drejer sig om; dernæst to feltstudier med henblik på at undersøge, hvad kontekstuel klinisk information betyder for klinisk arbejde og for visionen om ubegrænset interoperabilitet, og at vurdere mulighederne for at stille kontekstuel klinisk information til rådighed for klinisk arbejde.

Litteraturstudiet, som er beskrevet i det nedenstående afsnit 8.1, tager afsæt i visionen om ubegrænset pragmatisk interoperabilitet, og dennes krav om omfattende strukturering af klinisk information. Som anført i afsnit 7.3.3, side 32, hviler forestillingen om, at pragmatisk interoperabilitet kan opnås gennem strukturering, på Dey's kontekstperspektiv, og litteraturstudiet er således funderet i dette perspektiv.

De to feltstudier, der er omtalt i de efterfølgende afsnit, er funderet i hver sit kontekstperspektiv:

- Afsnit 8.2 (Bispebjerg-undersøgelsen), side 50, belyser kontekstuel klinisk information i Dey's perspektiv

- Afsnit 8.3 (Frederiksberg-undersøgelsen), side 63, belyser kontekstuel klinisk information i Dourish's perspektiv

De forskellige kontekstperspektiver giver anledning til en forskellig vinkling af forskningsspørgsmålene i de to feltstudier:

\section{Dey's perspektiv (Bispebjerg-undersøgelsen)}

I dette perspektiv opfattes kontekst deterministisk - som noget, der kan anskues udefra, kan forudsiges, styres og kontrolleres. Denne opfattelse af kontekst, der er beskrevet mere detaljeret i afsnit 7.3, side 33, giver anledning til en vinkling af forskningsspørgsmålene i retning af:

- Hvilken betydning har kontekstuel klinisk information for dagligt klinisk arbejde?

○ Hvad er det, der udgør kontekstuel klinisk information?

○ Hvilke dele består den af og hvordan er den sat sammen?

○ Kan man estimere cost-benefit ved forudseende fremskaffelse af oplysninger?

○ Er det umagen værd at fremskaffe (nogle af) oplysningerne på forhånd?

- I hvilket omfang kan kontekstuel klinisk information operationaliseres med henblik på at understøtte klinisk ræsonnement?

○ Kan kontekstuel klinisk information modelleres og udveksles? 
○ Kan man finde et minimumsdatasæt?

○ Kan man sørge for at informationen findes og er til rådighed, når den skal bruges?

\section{Dourish's perspektiv (Frederiksberg-undersøgelsen)}

I dette perspektiv opfattes kontekst non-deterministisk som det, den enkelte aktør inddrager for at give meningsfuld forståelse af ( $\sin )$ virkeligheden. Kontekst skabes således af aktøren i situationen. Denne opfattelse af kontekst er beskrevet mere detaljeret $i$ afsnit 7.3, side 33, og giver anledning til en vinkling af forskningsspørgsmålene i retning af:

- Hvilken betydning har kontekstuel klinisk information for dagligt klinisk arbejde?

- Er der - blandt alt det, som læger kontekstualiserer - klasser af information, som skiller sig ud - fx. ved at have en særlig (kvantitativ eller kvalitativ) betydning?

- I hvilket omfang kan kontekstuel klinisk information operationaliseres med henblik på at understøtte klinisk ræsonnement?

○ Hvordan operationaliserer man eventuelle klasser af klinisk information med særlig betydning?

○ Hvordan understøtter man lægernes mulighed for at kontekstualisere information?

\subsection{Teoretisk studie af kontekstuel klinisk informations betydning for klinisk arbejde ${ }^{1}$}

Som beskrevet tidligere har flere arbejder - fx.[6,7,9,41] - på grundlag af eksempler argumenteret for at kontekstuel information kan være af betydning for klinisk arbejde, men der foreligger ingen samlet beskrivelse af kontekstuelle faktorers bredde eller deres faktiske betydning i forhold til klinisk arbejde.

På denne baggrund var det interessant at få afklaret, om kontekstuel information også på et praktisk niveau har en reel betydning for klinisk arbejde, og hvilke informationstyper, det drejer sig om.

Det er tidligere, i afsnit 7.3.1, side 30, anført, at kontekstuelle faktorer udgør en en forudsætning for interoperabilitet. og adskillige kilder - fx. [32,62-64] - har i forhold til virkelighedens sundhedsvæsen beskrevet karakteristiske følger af manglende interoperabilitet: kliniske oplysninger bliver ikke genbrugt, og der udføres dobbeltregistrering og unødvendig gentagelse af undersøgelser. Det manglende genbrug af kliniske oplysninger er på mange måder uhensigtsmæssigt, herunder ikke mindst at det udgør en uhensigtsmæssig belastning af klinisk arbejde[62,64-68].

Med henblik på at undersøge sammenhængen mellem kontekstuel information og manglende genbrug af kliniske oplysninger blev det nedenfor beskrevne litteraturstudie gennemført, centreret om spørgsmålene:

\footnotetext{
${ }^{1}$ Dele af dette delstudie er beskrevet i Bilag 1 og Bilag 2, der indgår i litteraturlisten som henholdsvis [10] og [11].
} 
- Hvorfor genbruges kliniske oplysninger ikke?

- I hvilke situationer spiller kontekstuelle forhold en rolle for (manglende) datagenbrug?

\subsubsection{Metode}

Med henblik på at besvare disse spørgsmål blev der foretaget en kvalitativ litteraturgennemgang, som primært tog udgangspunkt i følgende litteratursøgning:

- En frasesøgning i PubMed efter "double documentation" OR "double registration" OR "dual documentation" OR "dual registration" (21 hits)

- En frasesøgning i PubMed efter "reuse*" AND ("clinical information" OR "clinical data") (54 hits)

- En søgning i GoogleScholar efter "reuse of clinical information" (29 hits)

- En søgning i GoogleScholar efter "reuse of clinical data" (44 hits)

Den samlede søgning resulterede - efter fjernelse af dubletter - i 139 hits. Det viste sig imidlertid hurtigt, at der i det sundhedsinformatiske domæne ikke fandtes stabile definitioner af datagenbrug og dobbeltregistrering. Blandt de fundne papers var datagenbrug og dobbeltregistrering ofte omtalt, men sjældent defineret, og da med vage eller tydeligt formålsbestemte definitioner - jf. eksemplerne i nedenstående Tabel 7. Desuden blev problematikker vedrørende genbrug af klinisk information kun berørt af 26 af de fundne papers, hvorfor der blev inddraget supplerende litteratur - dels kilder, som var kendt for at beskæftige sig med registreringspraksis og genanvendelse af kliniske oplysninger, dels gennem snowballing. Således blev der i alt inkluderet 46 artikler i studiet ${ }^{2}$.

Materialet blev først gennemgået med henblik på at opnå en operationel afgrænsning af datagenbrug og tilgrænsende begreber. Dernæst blev der foretaget en analyse af de angivne årsager til manglende genbrug af kliniske oplysninger og den potentielle betydning af kontekstuelle faktorer, og dernæst en kategorisering af de angivne årsager.

\subsubsection{Resultater}

\subsubsection{Begrebsmæssig afgrænsning}

For overhovedet at kunne beskæftige sig med kontekstuelle forholds indflydelse på dobbeltregistrering og datagenbrug var det nødvendigt at afgrænse disse begreber. I den inkluderede litteratur var der ganske få definitioner - jf. eksemplerne i Tabel 7:

\footnotetext{
2 Den samlede oversigt over inkluderet litteratur er anført i slutningen af Fejl: Henvisningskilde ikke fundet.
} 
Tabel 7. Definitioner af dobbeltregistrering

\begin{tabular}{|c|c|}
\hline Dobbeltregistrering/-dokumentation & Kilde \\
\hline $\begin{array}{l}\text { - oplysninger som er obligatoriske at indbe- } \\
\text { rette til LPR eller andre centrale sundhedsre- } \\
\text { gistre og også indsamles af de kliniske kvali- } \\
\text { tetsdatabaser }\end{array}$ & $\begin{array}{l}\text { Indenrigs- og Sundhedsministeriet, } \\
\text { Sundhedsstyrelsen. Analyse af kvali- } \\
\text { tetsoplysninger i Danmark - Juni } \\
\text { 2010. København, Danmark: Inden- } \\
\text { rigs- og Sundhedsministeriet; } 2010 .\end{array}$ \\
\hline $\begin{array}{l}\text { - when systems require staff (usually nurses) } \\
\text { to enter the data twice - into the computer } \\
\text { and again on a flow sheet }\end{array}$ & $\begin{array}{l}\text { Randolph AG, Haynes RB, et al. } \\
\text { Users' Guides to the Medical Litera- } \\
\text { ture: XVIII. How to use an article } \\
\text { evaluating the clinical impact of a } \\
\text { computer-based clinical decision sup- } \\
\text { port system. JAMA } 1999 \text { Jul } \\
\text { 7;282(1):67-74. }\end{array}$ \\
\hline $\begin{array}{l}\text { - at faggrupperne hver for sig registrerer sam- } \\
\text { me data i hver sin journal }\end{array}$ & $\begin{array}{l}\text { Lundgreen A, Hesselbo B, et al. } \\
\text { Tværfaglighed og dobbeltdokumenta- } \\
\text { tion i EPJ. 2006; URL: } \\
\text { ( http://projekter.aau.dk/projekter/file } \\
\text { s/6146655/Rapport\%20Tv } \\
\text { \%C3\%A6rfaglighed\%20og } \\
\text { \%20do.pdf ). Accessed 09/23/2013. }\end{array}$ \\
\hline $\begin{array}{l}\text { - når der både i lægejournal og sygeplejejour- } \\
\text { nal er noteret det samme, uanset om det er no- } \\
\text { teret med den latinske eller den danske beteg- } \\
\text { nelse, eks. åndenød og dyspnø }\end{array}$ & $\begin{array}{l}\text { Ølsgaard G, Nicolajsen L. Hvordan } \\
\text { sikres den sundhedsfaglige dokumen- } \\
\text { tation i en tværfaglig elektronisk pa- } \\
\text { tientjournal? Århus, Danmark: Århus } \\
\text { Amt; 2006. }\end{array}$ \\
\hline
\end{tabular}

Ved gennemgangen af den inkluderede litteratur var dobbeltregistrering (synonym: dobbeltdokumentation) hyppigt nævnt, men sjældent beskrevet, og de få fundne beskrivelser var baseret på et helt pragmatisk grundlag med snævert og formålsbestemt fokus på specifikke systemer og organisatoriske forhold (jf. eksemplerne i ovenstående Tabel 7 ).

Med henblik på at opnå en mere generel definition af dobbeltregistrering (som aktivitet) blev der foretaget en overordnet fortolkning af måden, hvorpå begrebet var omtalt i den indsamlede litteratur. Fortolkningen kan sammenfattes således:

- Den mest udbredte opfattelse af dobbeltregistrering er, at samme fænomen dokumenteres manuelt mere end én gang - fx. [32,62,69-72]. En enkelt kilde[72] anfører eksplicit transskription som et eksempel på dobbeltregistrering.

- Nogle få kilder sondrer mellem transskription og dobbeltregistrering - fx. [31,64] - og anser altså ikke manuel kopiering af data mellem informationssystemer for at være dobbeltregistrering. 
- Endelig demonstrerer enkelte kilder helt andre betydninger af termen, nemlig:

$\circ$ at dokumentere yderligere fænomener af samme type ('double sampling'), fx. [73,74]

$\circ$ at utilsigtet tælle samme fænomen mere end én gang - fx. [75,76].

Flere kilder beskriver eksplicit dobbeltregistrering som et alternativ til datagenbrug, fx. $[31,32,64,66,70,77]$. Et andet alternativ til datagenbrug - bla. beskrevet i $[63,66,77]$ - er dobbeltundersøgelse, hvor information tilvejebringes påny.

Ved at generalisere den fundne litteraturs behandling af begreberne "dobbeltregistrering" og "dobbeltundersøgelse", var det karakteristiske træk, at der i forbindelse med dataindsamling (lokalt, regionalt, nationalt) skabes (nær-)redundans, og at denne opstår ved en manuel proces.

På denne baggrund defineres datagenbrug, dobbeltregistrering og dobbeltundersøgelse således: datagenbrug

tilvejebringelse af oplysninger gennem automatisk kopiering eller behandling af eksisterende information

dobbeltregistrering (synonym: dobbeltdokumentation)

manuel registrering af oplysninger, som allerede eksisterer indenfor relevante kilder

dobbeltundersøgelse

fornyet frembringelse af oplysninger, som allerede eksisterer indenfor relevante kilder

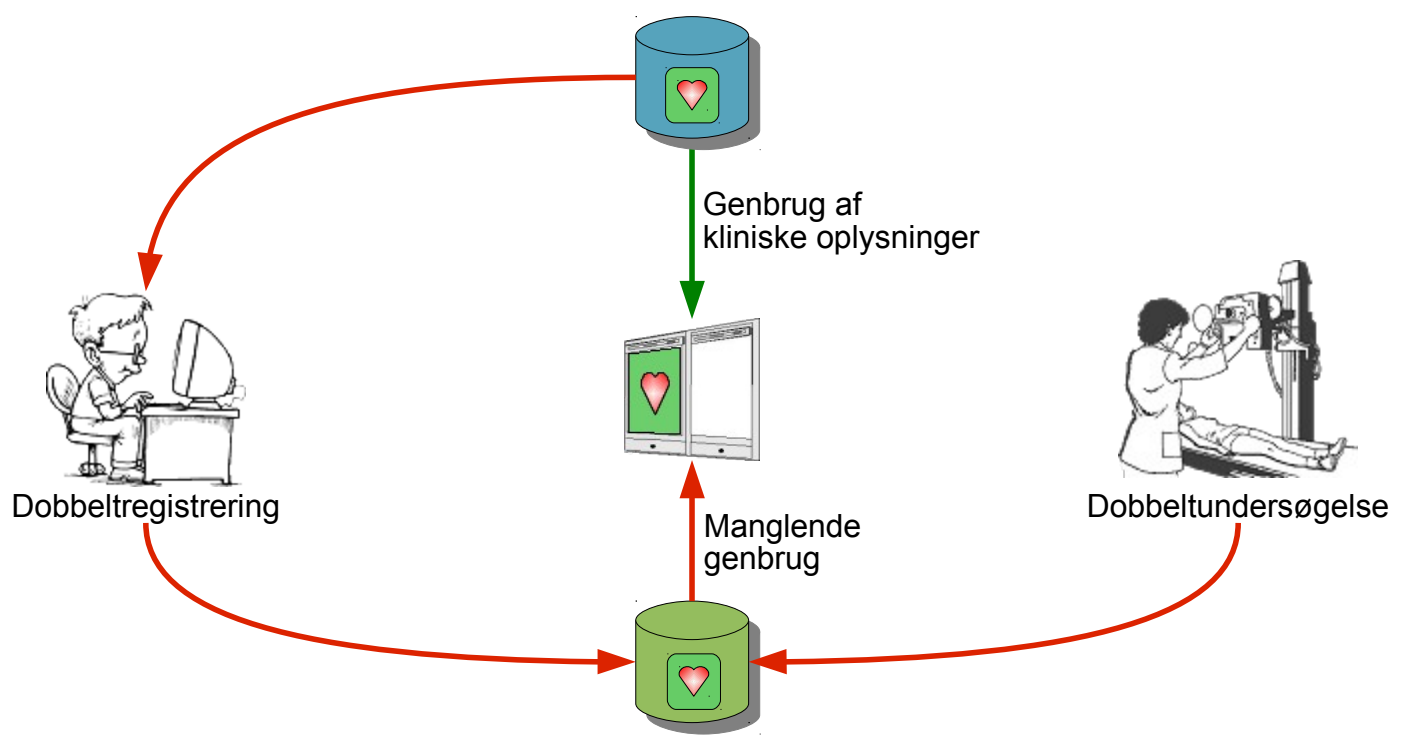

Figur 9. Genbrug af kliniske oplysninger - ja eller nej?

Som illustreret på Figur 9 betragtes manglende genbrug af kliniske oplysninger herefter som karakteriseret ved forekomsten af dobbeltregistrering eller dobbeltundersøgelse. 


\subsubsection{2. Årsager til manglende genbrug af kliniske oplysninger}

Den inkluderede litteratur angav forskellige årsager til, at kliniske oplysninger ikke var genbrugt. Disse årsager blev kategoriseret langs en akse af kompleksitet spændende fra simpel ikke-tilgængelig information til nogle meget komplekse og situationelle grunde til ikke at genbruge informationen. Denne kategorisering er overordnet angivet i nedenstående Tabel 8 og beskrevet mere indgående derunder:

Tabel 8. Årsager til manglende genbrug af klinisk information
Informationen er ...
A) ... ikke til stede, når eller hvor den skal bruges
B) ... til stede, men er utilgængelig
C) ... til stede, men anvendes normalt ikke i den foreliggende form
D) ... tilsyneladende til stede, men anses i situationen for at være utilstrækkelig

\section{A. Informationen er ikke til stede, når eller hvor den skal bruges}

Denne kategori omfatter fx. fraværende papirjournaler og uhensigtsmæssigt placerede arbejdsstationer[19,64].

\section{B. Informationen er til stede, men er utilgængelig}

Denne kategori omfatter situationer, hvor sundhedsarbejdere er afskåret fra at tilgå informationssystemer, fx. manglende systemadgang eller manglende samtykke[78,79].

\section{Informationen er til stede, men anvendes normalt ikke i den foreliggende form}

Denne kategori omfatter tre ganske forskellige typer af årsag til manglende genbrug af kliniske oplysninger - 1) tekniske, 2) politiske og 3) kvalitative årsager

Tekniske årsager til manglende genbrug af kliniske oplysninger har opnået betydelig omtale, fx. $[4,62,64,80,81]$. Det grundlæggende problem for denne årsag til manglende genbrug af oplysninger er manglende interoperabilitet mellem informationssystemer - fx. mellem papirbaserede og digitale systemer.

Med "politiske årsager" sigtes her til den sparsomt beskrevne situation, hvor en gruppe af sundhedsarbejdere mener at have behov for at manifestere autoritet og eksistensberettigelse gennem dokumentation af det udførte arbejde[82-84].

Opnåelse af en datakvalitet i kliniske oplysninger, som tillader genbrug, er gentagne gange beskrevet som en udfordring - ikke mindst i forbindelse med genanvendelse af data fra regionale og nationale sundhedsregistre [4,67]. 


\section{Informationen er tilsyneladende til stede, men anses i situationen for at være utilstrækkelig}

Denne kategori omfatter to forskellige typer af årsag til manglende genbrug af kliniske oplysninger: 1) manglende troværdighed og 2) manglende relevans.

Der findes kliniske situationer, som kræver ekstraordinært troværdig information[79,85], fx. at fastslå patientens identitet før udførelse af kirurgisk indgreb, eller at sikre sig at patienten har givet samtykke til abort.

Men også i ganske ordinære situationer kan der opstå tvivl om kliniske oplysningers troværdighed i et omfang, så oplysningerne ikke lægges til grund for beslutninger. Det kan være, at oplysningerne, måske med rette, opfattes som fejlagtige[67,80] - fx. pulsfrekvens 800 /min eller prostatisme-gener hos en kvinde. Eller at oplysningerne stammer fra en ukendt eller utroværdig kilde[7,40] - fx. usignerede journalnotater og oplysninger fra pårørende.

En anden årsag til ikke at genbruge kliniske oplysninger er manglende relevans i forhold til den aktuelle situation. Det kan være oplysninger med utilstrækkelig præcision[5,67] - fx. blodtryk angivet som "forhøjet" eller blodsukkermåling uden angivelse af omstændigheder (tidspunkt, faste, etc.). Det kan også være oplysninger, hvor den kontekst, hvori de er tilvejebragt, gør dem uanvendelige i den aktuelle situation[7,86] - fx. "gamle oplysninger" eller monitoreringsdata $i$ forhold til resultatet af systematisk undersøgelse.

\subsubsection{Diskussion}

Den afgrænsning af kliniske oplysningers genbrug, der er anvendt i dette litteraturstudie, er baseret på de anførte definitioner af dobbeltregistrering og dobbeltundersøgelse - definitioner, som begge sigter til nær-redundant information indenfor relevante kilder. Selv om definitionerne kan synes skarptskårne, omfatter de grader af vurdering:

For det første kan redundans-begrebet diskuteres. Ved både dobbeltregistrering og dobbeltundersøgelse er intentionen at skabe identisk information, men da informationen skabes ved manuelle processer - med de fejlkilder, som dertil hører - og da dobbeltundersøgelse nødvendigvis foregår under forandrede omstændigheder, kan den opnåede information aldrig med sikkerhed være identisk med den i forvejen registrerede. Det er derfor mere korrekt at beskrive den information, som søges tilvejebragt ved dobbeltregistrering og dobbeltundersøgelse, som substituerbar ("exchangeable"). Om således tilvejebragte oplysninger faktisk er substituerbare, må vurderes i den konkrete situation.

For det andet kræver begrebet "relevante kilder" en fortolkning, som ikke er triviel. Fx. vil man almindeligvis opfatte det lokale hospitals laboratoriesystem som en relevant kilde til blodprøvesvar. Derimod er det langt fra givet, at et laboratoriesystem i en anden region eller et andet land anses for 
en relevant kilde. Spørgsmålet om informationkilders relevans er i denne sammenhæng et spørgsmål om ambitionsniveau og tilgængelighed - egenskaber som kræver en situationel vurdering.

Enhver kategorisering af årsager har iboende den problematik, at kausalitet oftest er rekursiv - der kan som regel angives årsager til årsagernes årsager. Den beskrevne kategorisering af årsager til ikke at genbruge kliniske oplysninger er baseret på de umiddelbare årsager, som de er angivet eller beskrevet i den anvendte litteratur. SemanticHealth-rapporten[4] anfører nogle mere overordnede aspekter af betydning for interoperabilitet - tekniske, organisatoriske, legale og medicinske aspekter. Nedenstående Figur 10 illustrerer, hvordan disse aspekter kan relateres til de beskrevne kategorier.

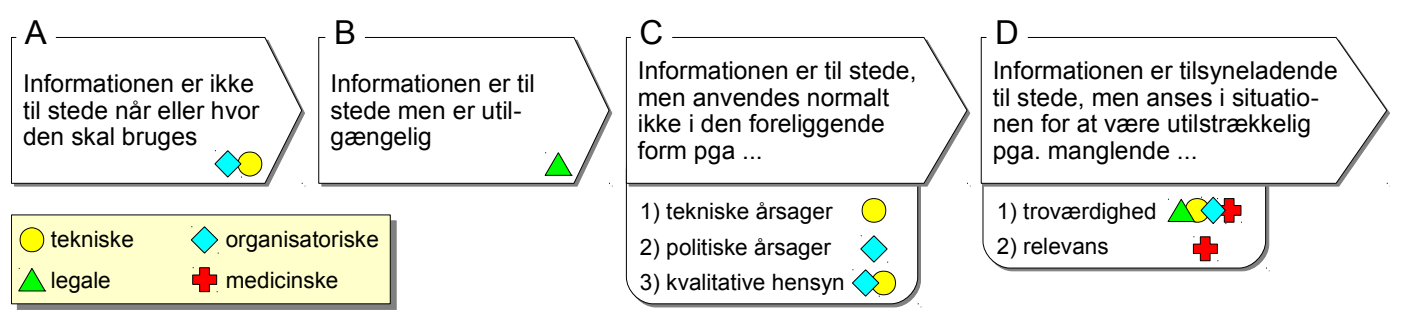

Figur 10. Årsager til manglende genbrug af klinisk information

Formålet med at kategorisere årsager til ikke at genbruge kliniske oplysninger var at belyse forskellige kontekstuelle faktorers betydning for manglende genbrug. De angivne årsager - væsensforskellige som de er - udgør tilsammen et bredt spektrum af kontekstuelle forhold, som alle kan være af betydning for, om kliniske oplysninger genbruges, fx:

- Placering, fysisk udformning og stabilitet af informationssystemer (A, D1)

- Syntaktisk udformning af informationssystemer (C1, C3)

- Tilrettelæggelse af arbejdsgange (A, C3, D1)

- Organisationsstruktur, bemanding og adgangskontrol (B, C2, D1)

- Aktualitet, præcision og troværdighed af klinisk information (C3, D1, D2)

Anskuet indenfor en ramme af informationslogistik - rette oplysninger på rette sted i rette tid - omfatter det ovenstående en række ordinære problemstillinger vedrørende rette tid og rette sted: umodne og gensidigt inkompatible systemer, uhensigtsmæssige arbejdsgange, umodne organisationer og generelt dårlig datakvalitet.

Af særlig interesse for denne afhandling med dens fokus på kontekstuel information er problemstillingerne vedrørende "rette oplysninger". De beskrevne kategorier C og D omfatter således årsager til manglende genbrug af klinisk information, hvor man i en given situation vurderer oplysningers anvendelighed på baggrund af kontekstuel information. De nedenstående eksempler illustrerer, 
hvordan kontekstuel information - anskuet i Dey's perspektiv - kan have betydning for oplysningernes anvendelse. Fx. kan oplysningernes alder være af betydning:

Eksempel 2. Hvor gammel er oplysningen?

En patients vægt blev registreret for 10 år siden i forbindelse med et generelt helbredstjek. Patienten skal nu opereres pga. en meniskskade, og som forberedelse til anæstesi skal man bruge patientens vægt. Kan man genbruge den eksisterende oplysning?

Kropsvægt kan ændre sig betydeligt indenfor den angivne tidsramme, og i betragtning af, at information om kropsvægten lægges til grund for dosering af anæstetika, vil denne situation normalt føre til, at vægten måles på ny.

Hvis oplysningen om kropsvægt ikke var så gammel - hvis oplysningen fx. var fra sidste uge - ville der ikke være nogen grund til aktuelt at gentage målingen.

Kliniske oplysningers brugbarhed kan desuden være afhængig af, hvad de skal bruges til:

Eksempel 3. Hvad skal oplysningen bruges til?

Med reference til forrige Eksempel 2: Hvis oplysningen ikke skulle anvendes i forbindelse med et perifert kirurgisk indgreb, men i forbindelse med at patienten skulle dialyseres, ville selv en uge gammel vægt være utilstrækkelig, og man ville måle patientens vægt i situationen.

Kilden til kliniske oplysninger kan også være af betydning:

Eksempel 4. Hvor kommer oplysningen fra?

Det er ikke ligegyldigt, hvor oplysningerne om, hvad patienten tager af medicin, kommer fra. De tillægges forskellig vægt afhængigt af om de kommer fra patienten selv, plejepersonale, pårørende eller hjemmehjælp.

Metode og andre omstændigheder i forbindelse med kliniske oplysningers tilvejebringelse kan også være af betydning:

Eksempel 5. Hvordan blev oplysningen tilvejebragt?

Der eksisterer for en lang række oplysningers vedkommende protokoller og vejledninger vedrørende oplysningernes tilvejebringelse - dels om metoden (fx. blodtryk målt med manometer og auskultation) og dels om omstændigheder, som det fx. afspejler sig i termerne arbejdsEKG, hvileblodtryk og fasteblodsukker. 
Og endelig kan forskellige typer af kliniske oplysninger have forskellig følsomhed for (kombinationer af) kontekstuelle forhold:

Eksempel 6. Hvad for en slags oplysning er det?

Som illustreret i Eksempel 2 vil oplysninger om vægt med tiden forældes. Det samme gælder i endnu højere grad oplysninger om fx. diurese eller tumorudbredelse, mens oplysninger om fx. køn er uafhængige af tid.

Oplysning om højde er også meget stabile i tid - medmindre patientens alder er lav.

Egenangivelse af fx. højde er generelt troværdig, mens angivelse af føde- og medicinindtag er mere usikre, og egenangivelse af tobak, alkohol og rusmidler ofte er decideret utroværdige.

Tilsammen tegner disse eksempler et billede af, at kontekstuel klinisk information (Dey's perspektiv) udgør et meget bredt spektrum. Eksemplerne illustrerer, at man for at kunne vurdere, om en given oplysning kan genbruges - og i givet fald med hvilken vægt - er nødt til at forholde sig til en lang række kontekstuelle faktorer, hvoraf flere er indbyrdes afhængige.

\subsubsection{Konklusion}

Dette litteraturbaserede delstudie belyser sammenhængen mellem kontekstuelle forhold og manglende interoperabilitet, som den i klinisk praksis viser sig gennem manglende datagenbrug: dobbeltregistrering og dobbeltundersøgelse.

Årsager til manglende genbrug af kliniske oplysninger er kategoriseret, og det er på baggrund af eksempler fra litteraturstudiet godtgjort, at der i klinikken sker dobbeltregistrering og dobbeltundersøgelse på grund af manglende eller utilfredsstillende kontekstuel klinisk information (Dey's perspektiv). De fundne eksempler suppleret med egne kliniske eksempler illustrerer, at kontekstuel klinisk information har mange facetter, og at spørgsmål om genbrug af en given klinisk oplysning ofte vil kræve en situationel vurdering, som tager hensyn til forhold til den givne situation, i forhold til oplysningens art, og i forhold til den situation, hvori oplysningen oprindeligt blev tilvejebragt.

\subsection{Kontekstuel klinisk information i Dey's perspektiv}

Den opfattelse af kontekst, der her er beskrevet som Dey's perspektiv, er vidt udbredt og har omfattende konsekvenser for den sundhedsinformatiske udvikling. Således er det en basal forudsætning for realiseringen af den tidligere beskrevne vision om ubegrænset pragmatisk interoperabilitet, at der er uhindret adgang til relevant information - dermed også til kontekstuelle kliniske oplysninger. Det er således nødvendigt at kunne udveksle disse, hvorfor de skal kunne udtrykkes - gerne på en

3 Dette delstudie er desuden beskrevet i Bilag 3, der indgår i litteraturlisten som [12]. 
standardiseret form. Herigennem kommer Dey's perspektiv - som anført i afsnit 7.3.3, side 32 - til at udgøre en forudsætning for at realisere visionen.

Derfor har det været af interesse ud fra dette perspektiv at belyse forskningsspørgsmålene:

- Hvilken betydning har kontekstuel klinisk information for dagligt klinisk arbejde?

- I hvilket omfang kan kontekstuel klinisk information operationaliseres med henblik på at understøtte klinisk ræsonnement?

Det er tidligere om Dey's perspektiv anført, at kontekst i alt væsentligt er givet ved de omstændigheder, hvorunder entiteter interagerer, at kontekst er baseret på en ekstern vurdering af, hvad en aktør kan lægge til grund for meningsfuld forståelse af et givet emne, og at kontekst med de rette modeller og værktøjer kan formuleres og udveksles. Kontekstens art og indhold kan - optimalt - forudsiges og gengives. I Dey's perspektiv kan forskningsspørgsmålene derfor omformuleres:

Kontekstuel information er i Dey's perspektiv en beskrivelse af omstændigheder, hvorunder entiteter interagerer, og anskuet i forhold til kliniske oplysninger er kontekstuel information således en beskrivelse af de omstændigheder, hvorunder de kliniske oplysninger er produceret - en opfattelse, der er helt i tråd med Berg's beskrivelse af sammenhængen mellem klinisk information og kontekst[7]:

Medical information is essentially bound to the context of its production. [7]

Denne type information vil fremadrettet blive benævnt og defineret således:

produktionskontekstuel klinisk information

beskrivelse af omstændighederne, hvorunder kliniske oplysninger er blevet produceret

Anskuet i Dey's perspektiv bliver forskningsspørgsmålet om kontekstuel klinisk informations betydning til spørgsmål om, hvilke informationstyper, den består af, og i hvilket omfang de er af betydning for klinisk arbejde.

I Dey's perspektiv kan information modelleres og udtrykkes struktureret, og spørgsmålet om operationalisering af kontekstuel klinisk information bliver derfor til spørgsmål om modellerbarhed og udveksling.

Anskuet i Dey's perspektiv udtrykkes forskningsspørgsmålene således:

- Hvad består produktionskontekstuel klinisk information af? Og hvilken betydning har den for lægers daglige kliniske arbejde?

- I hvilket omfang kan den modelleres, formuleres og udveksles? 


\subsubsection{Materiale og metoder}

Forskningsspørgsmålene blev i dette delstudie belyst ved at undersøge, hvordan læger efterspørger information med henblik på at kunne forstå og fortolke kliniske oplysninger. Dataindsamlingen skete ved hjælp af observation og fokusgruppeinterview, som beskrevet nedenfor.

Undersøgelsen blev tilrettelagt med henblik på at registrere hvilke informationstyper, læger efterspørger. Udgangspunktet var den kategorisering af sundhedsaktiviteter og klinisk information, der er beskrevet i afsnit 7.1.3 og illustreret i Figur $2 \& 3$, side 25. Med henvisning til denne analyseramme fremkommer klinisk information som et produkt af sundhedsaktivitet, og den tilhørende produktionskontekstuelle kliniske information fremkommer som en beskrivelse af sundhedsaktivitetens omstændigheder.

Undersøgelsen tog udgangspunkt i lægers behov for (supplerende) klinisk information - fx. for at en læge kan forholde sig til en patients diagnose, ønsker lægen en række oplysninger: hvem har stillet diagnosen, hvad fejler patienten i øvrigt, hvilke symptomer er der, hvor meget påvirker det patienten, hvilken behandling er forsøgt, hvor sikker er diagnosen, etc. Den anvendte kategorisering af kliniske informationstyper blev anvendt til at identificere lægernes efterspørgsel af produktionskontekstuel klinisk information, som det illustreres i det nedenstående Eksempel 7 :

Eksempel 7. Identifikation af produktionskontekstuel klinisk information

En læge i en given situation forholder sig til en patients diagnose. Lægen efterspørger i den forbindelse en række supplerende oplysninger:

\begin{tabular}{|l|c|}
\hline \multicolumn{1}{|c|}{ Efterspurgt oplysning } & Kategori \\
\hline a) Hvem har stillet diagnosen? & Produktionskontekstuel information \\
\hline b) Hvad fejler patienten i øvrigt? & Vurdering - diagnose \\
\hline c) Hvilke symptomer er der nu? & Vurdering - diagnose \\
\hline d) Hvor sikker var man på diagnosen? & Produktionskontekstuel information \\
\hline e) Hvor meget påvirker det patienten? & Vurdering - risiko/prognose \\
\hline f) Hvilken behandling er forsøgt? & Handlingsbeskrivelse \\
\hline g) Hvad var grundlaget for at stille diagnosen? & Produktionskontekstuel information \\
\hline
\end{tabular}

Tre af disse syv oplysninger - a, d og g - beskriver omstændighederne ved den vurdering, som har ført til diagnosen. Disse tre er eksempler på produktionskontekstuel klinisk information.

Spørgsmålet om konteksts betydning for dagligt klinisk arbejde er i tidligere arbejder blevet belyst gennem deduktion[6,7,9,41], hvorfor det var interessant at belyse det gennem observation. Med henblik på at operationalisere spørgsmålet, blev der valgt en pragmatisk afgrænsning: Kontekst an- 
ses for at være af væsentlig betydning, når der som konsekvens af (mangel på) kontekstuel information sker en eksplicit revurdering af situationer eller oplysninger.

\subsubsection{Observationer}

Denne del af undersøgelsen blev foretaget på kardiologisk afdeling, Bispebjerg Hospital ${ }^{4}$ i tidsrummet maj til juli, 2012, hvor der blev foretaget strukturerede observationer under 5 tilfældige mor genkonferencer med ca 25 deltagende læger. Morgenkonferencerne omfattede afrapportering af nyindlagte patienter og andre hændelser i vagten samt beskrivelser af faglige emner, typisk i form af patient-cases.

Emnet for observationerne var lægernes gensidige udveksling af oplysninger vedrørende patienter eller cases, med særligt fokus på de situationer med dialog, hvor læger efterspurgte oplysninger om patienterne.

De situationer, hvor lægerne i dialog udvekslede oplysninger om patienterne, blev i observationen anskuet som en række af dialoghændelser. Hver sådan dialoghændelse blev registreret under anven delse af den analyseramme, som er angivet i afsnit 7.1.3, side 24. Nedenstående Eksempel 8 illustrerer registreringsmetoden:

Eksempel 8. Registrering af en dialoghændelse

Læge A fortæller, at en patient er blevet DC-konverteret (sundhedsaktivitet: handling: 'DCkonvertering') med godt resultat. Læge B spørger relateret til denne procedure, hvad patienten fik af medicin (handlingsbeskrivelse: 'aktuel medicinering'), hvad blodtrykket var før konverteringen (observation: 'forudgående blodtryk') og hvor mange joule der blev givet (produktionskontekstuel information).

Registreringen blev udført ved hjælp af papir-skemaer, hvor væsentlige dele af registreringen - af hensyn til registreringshastigheden - kunne udføres som afkrydsning. Data fra observerede dialoghændelser blev samlet i en database, idet der for hver dialoghændelse blev registreret følgende:

- Emnet i fokus, anført som den overordnede type af sundhedsaktivitet, jf. Figur 2, side 25.

- Arten af efterspurgte oplysninger, overordnet anført som type, underordnet som tekst

- En række metadata om observationen (fx. afsender, modtager, afdeling og situation) beregnet på at kunne sammenligne med data opsamlet under andre omstændigheder end lægers morgenkonference.

\footnotetext{
${ }^{4}$ Betegnelsen Bispebjerg og Frederiksberg Hospitaler er udtryk for ét hospital på to matrikler. Hospitalet er et af Region Hovedstadens fire akuthospitaler og betjener 416.000 borgere i Københavns og Frederiksberg Kommuner. Hospitalet er et universitetshospital og er akkrediteret efter internationale standarder og Den Danske Kvalitetsmodel.
} 


\subsubsection{Fokusgruppeinterview}

Med henblik på at få en dybere og mere nuanceret forståelse af kontekst, blev observationerne suppleret med interview. Disse blev udført som fokusgruppeinterview[87] af læger fra afdelingen. De deltagende læger blev ikke udvalgt efter andre kriterier end, at de var villige til at deltage i interviews - der var således deltagelse af både nyuddannede og meget erfarne læger. Interviews blev afholdt som 5 seancer med deltagelse af 3-6 læger.

Idet det - som anført ovenfor - var en arbejdshypotese, at bestemte typer af sundhedsaktivitet giver anledning til kontekstualisering af bestemte typer af oplysninger, var det væsentligt at sikre, at alle typer af sundhedsaktivitet (jf. Figur 2, side 25) blev behandlet i interview. Derfor blev der som forberedelse fremstillet 78 kort med udsagn hentet fra tilfældigt udvalgte patienters journal-indhold, fx:

- "Pt. har indvilliget i PCI" (Observation)

- "Der blev anlagt drop" (Handling)

- "Diagnose: Feber uden kendt årsag. DR508B"6" (Vurdering-Diagnose)

- "Pt. bør tabe mindst 10 kg." (Vurdering-Mål)

- "Plan: Observeres i telemetri næste 24 timer" (Ordination)

Fokusgruppeinterview blev arrangeret således, at deltagerne på skift trak et tilfældigt kort. Kortets udsagn dannede baggrund for en diskussion om, hvilke supplerende oplysninger deltagerne ønskede for at kunne forstå eller kunne agere på udsagnet. Udsagnene blev præsenteret kontekstløst, og deltagerne måtte således selv forestille sig kliniske situationer, som gav anledning til at ønske supplerende oplysninger.

De eksempler på supplerende information, som deltagerne bidrog med, blev løbende visualiseret for dem i form af et tegnet diagram. Resultaterne blev således løbende afstemt med deltagerne. Efterfølgende blev resultaterne lagt ind i samme database som resultaterne fra observationerne.

\subsubsection{Resultater}

\subsubsection{Observationer}

Fremlæggelse af patienter (evt. indirekte, gennem cases) ved lægernes morgenkonferencer fulgte et simpelt skema: patienten blev kortfattet præsenteret af en enkelt læge, hvorefter der udspandt sig en dialog med spørgsmål og svar, hvis formål tydeligt var at tilvejebringe så mange oplysninger om patienten, at man kunne nå til en kollektiv opfattelse eller beslutning. Oplysninger, som fremkom

\footnotetext{
5 Percutan Coronar Intervention, ballonudvidelse

6 SKS-kode med betydningen: "Vedvarende feber af ukendt årsag"
} 
under disse dialoger, gav jævnligt anledning til revurdering af patienternes behandling og tilstand typisk i form af supplerende undersøgelser, ændret medicinering eller afklaring af diagnoser.

Under konferencerne blev der registreret 51 dialoghændelser med i alt 206 kliniske oplysninger. Heraf var 54 (26\%) produktionskontekstuel klinisk information.

Den produktionskontekstuelle kliniske information blev typisk efterspurgt i situationer, hvor en enkelt oplysning gav anledning til spørgsmål vedrørende de omstændigheder, hvorunder oplysningen var blevet produceret - fx. hvem der havde udført en undersøgelse, om oplysninger kom fra personale eller patient, hvordan dokumenterede procedurer var udført, etc. Sådan efterspørgsel af produktionskontekstuel klinisk information førte ofte til yderligere "spørgen ind" til den tilgrundliggende sundhedsaktivitet med det tydelige formål, at udøve kildekritik og foretage en vurdering af informationens troværdighed og hvor megen vægt den kunne tillægges. Fx. et spørgsmål om, hvornår en måling var foretaget, blev fulgt op af yderligere spørgsmål om, hvorvidt målingen havde været planlagt eller var foranlediget af en aktuel årsag, og hvorfor var man i den situation gået i gang med at måle, og var måleresultatet ikke forudsigeligt i situationen, etc.

Mange af de produktionskontekstuelle oplysninger gav i situationen anledning til eksplicit revurdering, og opfyldte dermed dette delstudies pragmatiske afgrænsning af, hvorvidt information er af væsentlig betydning. I nedenstående Tabel 9 er anført en række observerede eksempler på produktionskontekstuel klinisk information, som gav anledning til eksplicit revurdering, ordnet efter den sundhedsaktivitet, hvis resultat var genstand for revurdering:

Tabel 9. Observerede eksempler på produktionskontekstuel klinisk information af væsentlig betydning

\begin{tabular}{|c|c|}
\hline $\begin{array}{l}\text { Tidligere } \\
\text { sundhedsaktivitet }\end{array}$ & $\begin{array}{l}\text {.. blev revurderet på grundlag af (manglende) } \\
\text { produktionskontekstuel klinisk information }\end{array}$ \\
\hline \multirow{2}{*}{ Vurdering } & "Stod der noget om, hvor sikker hun var på den diagnose?" \\
\hline & "Hvis diætisten siger at han bør tabe $20 \mathrm{~kg}$, er det rigtigt." \\
\hline \multirow{3}{*}{ Observation } & $\begin{array}{l}\text { "Han virkede nervøs, så måske pyntede han på, om han } \\
\text { faktisk tager sin medicin." }\end{array}$ \\
\hline & $\begin{array}{l}\text { "Flebografien blev jo ikke udført her, så vi kan ikke lægge } \\
\text { den til grund for en behandling med en vis risiko." }\end{array}$ \\
\hline & "Men dette her EKG er jo mere end en uge gammelt!" \\
\hline \multirow{2}{*}{ Handling } & \begin{tabular}{|l} 
"Den ekkokardiografi burde have været udført af en \\
specialist."
\end{tabular} \\
\hline & $\begin{array}{l}\text { "Er du sikker på, at hun blev informeret i henhold til vores } \\
\text { retningslinjer?" }\end{array}$ \\
\hline
\end{tabular}




\begin{tabular}{|c|c|}
\hline $\begin{array}{c}\text { Tidligere } \\
\text { sundhedsaktivitet }\end{array}$ & $\begin{array}{c}\text {.. blev revurderet på grundlag af (manglende) } \\
\text { produktionskontekstuel klinisk information }\end{array}$ \\
\hline \multirow{3}{*}{ Ordination } & $\begin{array}{c}\text { "Jeg ville have ordineret sotalol som tabletter, men vi havde } \\
\text { det kun til injektion." }\end{array}$ \\
\cline { 2 - 2 } & $\begin{array}{c}\text { "Jamen hvis blodtrykket er normalt nu, er der jo ingen grund } \\
\text { til at starte behandling med betablokker." }\end{array}$ \\
\hline
\end{tabular}

\subsubsection{Fokusgruppeinterview}

Under fokusgruppeinterviews blev der registreret 47 dialoghændelser med i alt 67 kliniske oplysninger. Heraf var 40 (60\%) produktionskontekstuel klinisk information.

Udgangspunktet for interviews var enkeltstående kliniske oplysninger uden nogen kontekstuel ramme. Adskillige af deltagerne gav udtryk for frustration over den kontekstløse præsentation, og gav tydeligt udtryk for, at det var svært at "se patienten i situationen". Det, at oplysningerne blev præsenteret kontekstløst, gav gentagne gange anledning til diskussion om, hvilke kliniske situationer, der ville give anledning til behov for hvilke supplerende oplysninger. I disse diskussioner blev det gentagne gange fremført, at selvom en oplysning - fx. beskrivelse af en operation - i de fleste tilfælde blot er af interesse som en overordnet baggrundsbeskrivelse, så var der situationer, hvor den samme operations præcise detaljer kan have vital betydning.

Spørgsmålet om oplysningers relevans havde en fremtrædende plads i deltagernes diskussioner, og der var et gentaget ønske om supplerende produktionskontekstuelle oplysninger med det formål, at kunne vurdere vægten og relevansen af den angivne oplysning.

Lige som ved observation af morgenkonferencer blev det flere gange observeret, at lægerne "spurgte ind" til omstændighederne ved tilvejebringelsen af kliniske oplysninger med det tydelige formål, at udfordre oplysningernes troværdighed og vægt. Nogle gange manifesterede denne efterspørgsel af produktionskontekstuel klinisk information sig som en gruppe spørgsmål med direkte relation til den informationsskabende sundhedsaktivitet - fx. hvornår en undersøgelse var foretaget, af hvem og hvorfor. Andre gange manifesterede den sig som en kæde af spørgsmål med indbyrdes relation, fx. et spørgsmål om, hvor en undersøgelse var foretaget, blev efterfulgt af en diskussion om forskellige afdelingers undersøgelseskvalitet, blev efterfulgt af en diskussion om hvilke faggrupper, som var involveret i den slags undersøgelser, blev efterfulgt af en diskussion om kliniske oplysningers generelle troværdighed. 


\subsubsection{Diskussion}

\subsubsection{De anvendte metoder}

I forbindelse med observation af lægernes morgenkonferencer blev dialoghændelser registreret realtime på et dertil udviklet papirskema. Denne metode indebærer to svagheder: For det første var udvekslingen af information mellem observanderne så hurtig, at der - selv med et skema optimeret til hurtig afkrydsning - uden tvivl er overset dialoghændelser. En bedre metode havde været videounderstøttet observation med sekundær registrering. For det andet indebærer registreringen en fortolkning, og det havde derfor været hensigtsmæssigt med en form for kvalitetskontrol - fx. med flere samtidige registratorer.

I forbindelse med fokusgruppeinterviewene blev de enkelte kliniske oplysninger som beskrevet præsenteret uden sammenhæng, hvilket betød, at deltagerne selv skulle danne sig et billede af situationer, hvor oplysningen passede ind. Dette krav til fantasi og abstraktion var for nogle deltagere en tydelig kilde til frustration. Selvom det genererede et rigt materiale i form af betydelig diskussion om forskellige kliniske scenarier, er det indtrykket, at anvendelsen af (mikro)cases havde været at foretrække.

\subsubsection{Hvad består produktionskontekstuel klinisk information af?}

Produktionskontekstuel klinisk information kan formelt afgrænses som 'beskrivelse af omstændighederne, hvorunder kliniske oplysninger er blevet produceret' og dette delstudie har tydeligt vist, at læger benytter denne type information til at udøve kildekritik og foretage en vurdering af den kliniske informations troværdighed og hvor megen vægt den kan tillægges.

Det har ikke været muligt at identificere en åbenlys struktur i den registrerede mængde af produktionskontekstuelle kliniske oplysninger, hvilket synes at være helt på linje med andres forsøg på at strukturere kontekstuel klinisk information[37].

Da produktionskontekstuelle oplysninger i sagens natur har tæt relation til de sundhedsaktiviteter, hvis omstændigheder de beskriver, var det nærliggende at anskue produktionskontekstuel klinisk information i forhold til de traditionelle attributter for en aktivitet - hvem, hvad, hvor, hvornår, hvorfor og hvordan. Denne gruppering er illustreret i Tabel 10 og på den efterfølgende Figur 11 : 
Tabel 10. Forsøg på strukturering af observeret produktionskontekstuel klinisk information

\begin{tabular}{|l}
$\begin{array}{l}\text { Hvem } \\
\text { Patient } \\
\text { fx. liggende eller stående; hvilende eller i aktivitet } \\
\text { fx. åndelig habitus }\end{array}$ \\
Sundhedsarbejder(e) \\
fx. læge eller sygeplejerske \\
fx. yngre eller erfaren læge; specialist eller generalist
\end{tabular}

I Tabel 10 er eksempler på produktionskontekstuel klinisk information vist grupperet efter de traditionelle attributter for beskrivelse af en (sundheds)aktivitet, og denne strukturering er yderligere illustreret i Figur 11: 


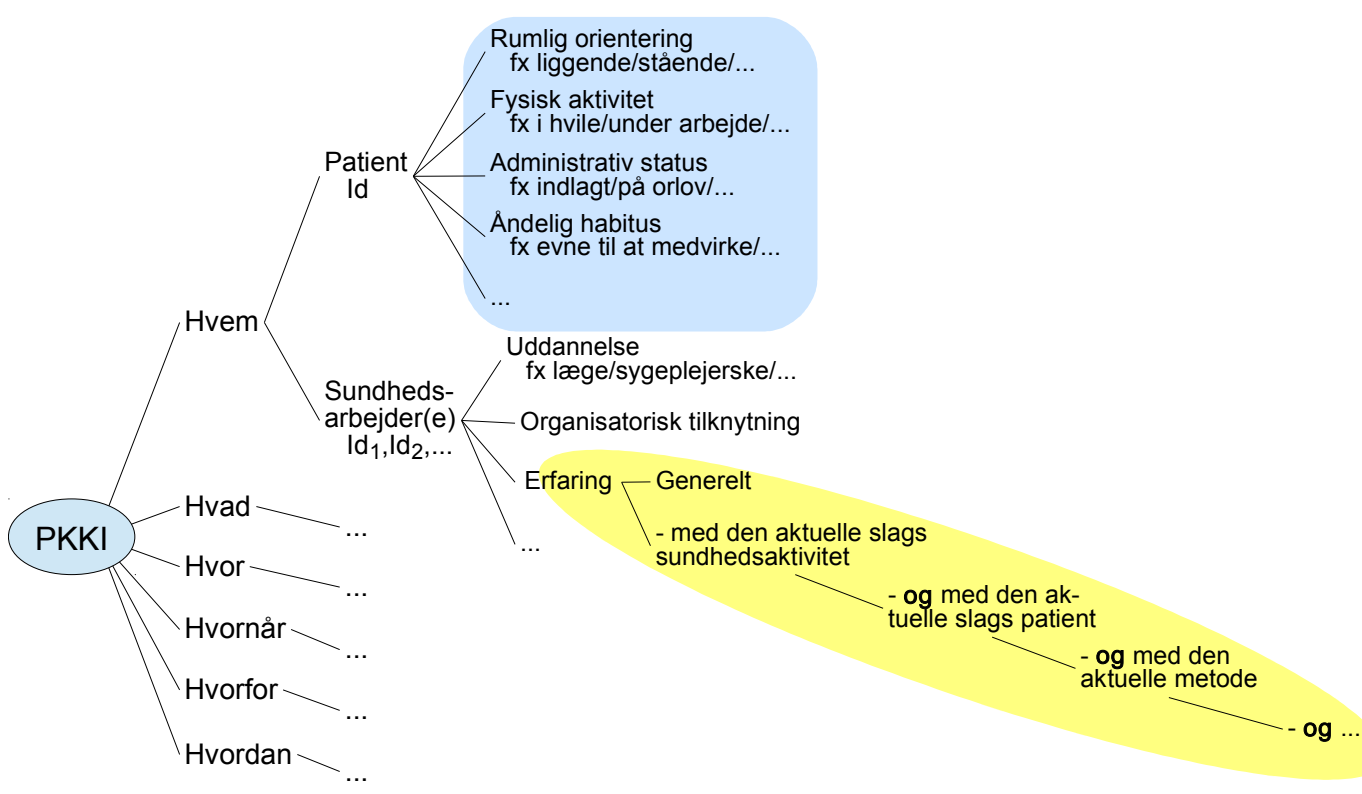

Figur 11. Forsøg på strukturering af produktionskontekstuel klinisk information (PKKI). Se forklaring nedenstående.

Figur 11 viser produktionskontekstuel klinisk information afbildet i strukturen fra Tabel 10, og med en enkelt gren (hvem-grenen) udfoldet med eksempler på observerede attributter. Det er tydeligt, at der spændes over nogle meget forskellige slags oplysninger (markeret blå), hvoraf nogle (fx. administrativ status) let lader sig udtrykke vha. klassifikation, mens andre (fx. åndelig habitus) har meget omfattende udfaldsrum, hvor det næppe er muligt at definere et endeligt værdisæt. Det bemærkes desuden, at der optræder information i en hierarkisk struktur (markeret gul) uden at der umiddelbart anes nogen afgrænsning af hierarkiets dybde.

Det må antages at nogle af de viste grene (fx. Hvor og Hvornår) er mere tilgængelige for strukturering, men sammenfattende må det siges, at produktionskontekstuel klinisk information omfatter nogle meget forskellige informationstyper, med nogle dårligt afgrænsede udfaldsrum i en kompleks struktur.

Det skal endvidere bemærkes, at visse typer af produktionskontekstuel information ikke vil blive registreret med den anvendte observationsmetode. Udover det mørketal, som knytter sig til registreringsmetoden og er nævnt ovenfor, er der et mørketal, som beror på, at visse typer information ikke eller kun i begrænset omfang italesættes ved lægers morgenkonferencer - fx. lægernes kendskab til hinandens kompetencer og modus operandi, samt deres kendskab til plejepersonalet og til afdelingens rutiner og sædvaner. Flere eksempler er beskrevet $\mathrm{i}$ afsnit 7.3.5, side 35, og bidrager yderligere til opfattelsen af, at produktionskontekstuel klinisk information omfatter nogle meget forskellige informationstyper med dårligt afgrænsede udfaldsrum i en meget kompleks struktur. 


\subsubsection{Er produktionskontekstuel klinisk information det samme som metadata?}

Som beskrevet af Burnett et al.[88] eksisterer der to ganske forskellige opfattelser af metadata ${ }^{7}$ :

den bibliografiske tilgang

- med fokus på beskrivelse af informationsmediet. Denne opfattelse kan illustreres med metadata-definitionen fra NISO[89]: structured information that describes, explains, locates, or otherwise makes it easier to retrieve, use, or manage an information resource den datalogiske tilgang

- med fokus på beskrivelse af strukturen af og meningen med informationsindholdet. Denne opfattelse kan illustreres med metadata-definitionen fra ISO/IEC 111791:2004[90]:data that defines and describes other data

Produktionskontekstuel klinisk information kan uden tvivl omfatte den bibliografiske opfattelse af metadata: hvem forfattede den kliniske information, hvor og hvornår blev informationen dokumenteret, i hvilket system, etc.

Derimod gør produktionskontekstuelle oplysninger ganske vist en modtager i stand til at forstå den kliniske information i et særligt perspektiv, men de udgør ikke i sig hverken definitioner eller beskrivelser af den kliniske information. Der er således ikke tale om metainformation i den datalogiske opfattelse af begrebet.

Og selv hvis man vælger den meget afslappede (og vidt udbredte) måde at anskue metadata-begrebet: "data om data", bemærkes det, at produktionskontekstuel klinisk information rigtigt nok omfatter oplysninger om den kliniske information, men derudover også oplysninger om oplysningerne om ... informationen (meta-meta) - som illustreret i den hierarkiske (gule) del af Figur 11, side 59.

Konklusionen må således - uanset hvilken metadata-opfattelse man lægger til grund - være, at produktionskontekstuel klinisk information ikke er det samme som den kliniske informations metadata.

\subsubsection{I hvilket omfang har produktionskontekstuel klinisk information betydning for lægers} daglige kliniske arbejde?

Produktionskontekstuel klinisk information udgjorde samlet godt en tredjedel af den i studiet registrerede mængde af klinisk information. Den meget høje forekomst (60\%) under fokusgruppeinterview er uden tvivl foranlediget af interviewsituationen, hvor stillingtagen til kontekstløs klinisk information indebærer uvante grader af variabilitet, og dermed animerer til indhentning af

\footnotetext{
7 En diskussion om forskellen på data og information ligger uden for denne afhandlings scope. I dette afsnit skal "data" opfattes synonymt med "information" - ikke mindst fordi den refererede standard ISO/IEC 11179-1:2004 definerer data som "re-interpretable representation of information in a formalized manner suitable for communication, interpretation, or processing".
} 
produktionskontekstuel klinisk information med henblik på at sikre troværdighed og sammenhæng. I modsætning hertil afspejler observation af lægernes morgenkonferencer i langt højere grad den kliniske virkelighed, og der blev her registreret en forekomst af produktionskontekstuel klinisk information på $26 \%$.

Den observerede mængde af produktionskontekstuel klinisk information, måden, hvorpå lægerne håndterede den, og den lethed, hvormed de som konsekvens ændrede vurderinger og planer, efterlader et indtryk af, at omgangen med produktionskontekstuel klinisk information er en integreret del af de observerede lægers hverdag. Som illustreret i Tabel 9, side 55, blev der gentagne gange observeret eksempler på produktionskontekstuel klinisk information, som gav anledning til eksplicit revurdering og dermed opfyldte dette delstudies pragmatiske afgrænsning af, hvorvidt information er af væsentlig betydning. På denne baggrund konkluderes, at produktionskontekstuel klinisk information er essentiel for lægers daglige kliniske arbejde.

I forhold til visionen om ubegrænset pragmatisk interoperabilitet må udveksling af produktionskontekstuel klinisk information derfor anses for at være en absolut betingelse - en slutning, som er på linje med andres arbejder, jf. den tidligere omtale heraf $i$ afsnit 7.3.1, side 30 .

\subsubsection{I hvilket omfang kan produktionskontekstuel information operationaliseres?}

I Dey's perspektiv omfatter operationalisering af kontekst, at de produktionskontekstuelle oplysninger retrospektivt kan gengives og udveksles og prospektivt kan forudsiges. Som anført i afsnit 7.3.3, side 32, udgør dette grundlaget for at kunne realisere visionen om ubegrænset pragmatisk interoperabilitet. Imidlertid må man forvente, at produktionskontekstuel klinisk information i praksis kun kan udveksles i begrænset omfang af følgende årsager:

\section{Struktur}

Udtømmende struktureret fremstilling af produktionskontekstuel klinisk information er næppe muligt. Som anført på de foregående sider er det vist, at produktionskontekstuel klinisk information består af noget meget forskelligartet information, med dårligt afgrænsbare udfaldsrum, udefinerede værdisæt og en vanskeligt modellerbar struktur.

\section{$\underline{\text { Volumen }}$}

For at opfylde visionen om ubegrænset pragmatisk interoperabilitet er det et krav, at der kan tilvejebringes tilstrækkelig information til at tilfredsstille enhver fremtidig sundhedsarbejders behov for produktionskontekstuel klinisk information. Det vil kræve information i et omfang, som - selv i forhold til de store mængder klinisk kerne-information - er enormt. Sådanne mængder af information rejser en række logistiske problemer, hvoraf det væsentligste nok er selve tilvejebringelsen: at doku- 
mentere så meget kompleks og vidtgående kvalitativ information, vil kræve manuel registrering i et omfang, som næppe er realiserbart, og hvor ulemperne let kommer til at overskygge fordelene[7].

\section{$\underline{\text { Udbud vs. efterspørgsel }}$}

Og endelig er der et helt grundlæggende problem forbundet med udveksling af produktionskontekstuel klinisk information, nemlig at informationen tilvejebringes af én aktør på ét tidspunkt, mens behovet for information afgøres af andre aktører på andre tidspunkter, jf. Figur 8, side 38. Det er derfor nødvendigt på forhånd og udtømmende at specificere art og omfang af den kontekstuelle information, som skal registreres.

På dette grundlag anses forestillingen om ubegrænset pragmatisk interoperabilitet for at være en illusion. Og selv med et betydeligt reduceret ambitionsniveau - fx. at opnå pragmatisk interoperabilitet mellem to sygehuse i samme region - forekommer opgaven at være udfordrende. En realistisk udveksling af produktionskontekstuel klinisk information må baseres på aftaler og standarder, som specificerer, hvad der skal registreres hvornår, og som tager hensyn til den resulterende registreringsbyrde.

\subsubsection{Undersøgelsen anskuet i et andet perspektiv}

Formålet med denne undersøgelse var at belyse kontekstuel klinisk information anskuet i Dey's perspektiv. Selvom undersøgelsens design ikke er beregnet på at belyse kontekstuel information anskuet i Dourish's perspektiv, fremviser den dog detaljer, som illustrerer perspektivet:

I Dourish's perspektiv omfatter operationalisering af kontekst, at man i situationen let kan kontekstualisere den information, man måtte finde af relevans. Denne undersøgelse var ikke designet til at belyse dette aspekt af kontekstualisering, men det bemærkes dog, at morgenkonferencerne gjorde det muligt for lægerne - gennem dialog - at foretage en meget rig kontekstualisering af klinisk information. Formodentlig langt rigere, end hvis de skulle have tilegnet sig den kontekstuelle information fra afdelingens kliniske informationssystemer.

I forbindelse med fokusgruppeinterview opstod der, som anført, diskussioner om, hvilke supplerende oplysninger, der er relevante i hvilke situationer. Disse diskussioner illustrerede med tydelighed, hvordan de deltagende læger opfattede kontekstualitet som situationel, idet det flere gange blev anført, at en given klinisk oplysnings vægt og relevans kan være helt afhængig af situationen. Den kan således i nogle situationer være helt underordnet, og i andre være af afgørende betydning.

Den "spørgen ind til" omstændighederne, hvorunder kliniske oplysninger var produceret, som blev registreret både under observationer og fokusgruppeinterview, demonstrerede, at kontekst er bestemmende for, hvad der yderligere kontekstualiseres, som er bestemmende for, hvad der yderligere 
kontekstualiseres, som er bestemmende for... Anskuet således, kan kontekstualisering opfattes som en (ubegrænset) rekursiv funktionalitet - jf. evt. Figur 11, side 59.

\subsubsection{Konklusion}

Kontekstuel klinisk information, som den opfattes i Dey's perspektiv - produktionskontekstuel klinisk information - udgør en beskrivelse af omstændighederne, hvorunder kliniske oplysninger er blevet produceret. Det drejer sig om meget heterogen information med dårligt afgrænsbare udfaldsrum, udefinerede værdisæt og en vanskeligt modellerbar struktur.

Undersøgelsen har påvist, at produktionskontekstuel klinisk information er essentiel for lægers kliniske arbejde, idet den anvendes til i konkrete situationer at vurdere kliniske oplysningers vægt og relevans.

Dels på grund af den vanskeligt operationaliserbare struktur, dels på grund af den potentielle mængde og dels på grund af vanskeligheden med målrettet tilvejebringelse udgør det er betydeligt problem at formulere og udveksle produktionskontekstuel klinisk information.

\subsection{Kontekstuel klinisk information i Dourish's perspektiv ${ }^{8}$}

I den opfattelse af kontekst, der her er beskrevet som Dourish's perspektiv, er det et centralt aspekt, at kontekst ikke er forudbestemt, men skabes af aktøren i situationen. Hvor Dey's perspektiv tilsigter at løse et generaliseret problem med at repræsentere og udveksle kontekstuel information, tilsigter Dourish's perspektiv at løse et situationelt problem med at understøtte aktørens kontekstualisering.

Årtiers udvikling af sundheds-it har været baseret på en opfattelse af kontekstuel klinisk information ud fra Dey's perspektiv. Det har derfor været af interesse at overveje, hvad en kontekstopfattelse i Dourish's perspektiv kan bidrage med, herunder i dette perspektiv at belyse forskningsspørgsmålene:

- Hvilken betydning har kontekstuel klinisk information for dagligt klinisk arbejde?

- I hvilket omfang kan kontekstuel klinisk information operationaliseres med henblik på at understøtte klinisk ræsonnement?

Anskuet i Dourish's perspektiv bliver noget kontekst i kraft af, at en aktør i situationen tillægger det rollen som kontekst.

Something is context because of the way it is used in interpretation, not due to its inherent properties[38].

\footnotetext{
8 Dette delstudie er desuden beskrevet i Bilag 4, der indgår i litteraturlisten som [13].
} 
Kontekst opstår således af aktørens (måske implicitte) opfattelse af, hvad der er relevant i situationen. I Dourish's perspektiv kan forskningsspørgsmålene derfor omformuleres:

I Dourish's perspektiv er spørgsmålet om kontekstuel klinisk informations betydning i sig selv uinteressant: kontekstuel klinisk information er det informatiske fundament for klinisk arbejde. Mere interessant er, hvordan kontekstualiseringen foregår, og om der i det kontekstualiserede er klasser af information, som skiller sig ud - fx. ved at have en særlig (kvantitativ eller kvalitativ) betydning. På samme måde bliver i Dourish's perspektiv spørgsmål om operationalisering af kontekstuel klinisk information til spørgsmål om, i hvilket omfang det er muligt at understøtte kontekstualiseringen.

Anskuet i Dourish's perspektiv udtrykkes forskningsspørgsmålene således:

- Hvordan foregår lægers kontekstualisering?

- Kan der identificeres mønstre i kontekstualiseringen?

- I hvilket omfang kan kontekstualiseringen understøttes?

Mens der, som anført i afsnit 7.3.6, side 38, ikke foreligger undersøgelser, hvor man med udgangspunkt i lægers faktiske tilegnelse af klinisk information har forsøgt at kortlægge deres klinisk-logiske informationsstruktur, har Kannampallil et al. [61] demonstreret, hvordan en konkret journal (suboptimalt) understøttede lægernes kontekstualisering af kliniske oplysninger. Fra det studie konkluderes:

A process of local optimization drove the information seeking process: physicians utilized information that maximized their information gain even though it required significantly more cognitive effort. [61]

Det var på dette grundlag en nærliggende tanke, at man kan understøtte lægers kontekstualisering ved at bygge sundheds-it, som præsenterer kliniske oplysninger i en form, som (bedre) matcher lægers klinisk-logiske informationsstruktur.

Derfor blev det nedenfor beskrevne feltstudie udført med henblik på at besvare en række successive spørgsmål:

- Er det muligt at afdække og beskrive en læges klinisk-logiske informationsstruktur - den struktur, hvori lægen in-vivo samler oplysningerne om en given patient?

- Kan man beskrive en relation mellem klinisk-logisk informationsstruktur og den struktur, som anvendes $\mathrm{i}$ et informationssystem?

- Findes der generelle klinisk-logiske informationsstrukturer - dvs. strukturer, som er fælles for læger?

- Kan sådanne udnyttes konstruktivt til at understøtte kontekstualisering? 


\subsubsection{Materiale og metoder}

Med henblik på at afdække, hvordan læger kontekstualiserer klinisk information, fulgte jeg otte læger på stuegang. Studiet blev udført på medicinsk afdeling, Frederiksberg Hospital ${ }^{9}$, halvdelen i november 2012, resten i maj 2013.

Da det overordnede emne var kontekstualisering, fokuserede undersøgelsen på en for læger almindelig situation, hvor det at skabe meningsfuld forståelse af forhold og situationer er centralt, og hvor det er let at studere lægens kontekstualiseringsproces. Jeg valgte at observere den situation, hvor en erfaren læge gennemgår de patienter, som er indlagt indenfor det sidste døgn. Situationen udmærker sig ved, at lægen ikke - eller kun helt overfladisk - kender patienten, og at der i situationen foreligger en lang række dokumenterede oplysninger, som lægen kan vælge at kontekstualisere.

De deltagende læger blev ikke udvalgt efter andre kriterier end, at de udførte den ovennævnte arbejdsgang, og at de var villige til at deltage i video-understøttet observation. De var informerede om, at formålet med undersøgelsen var en kortlægning af, hvordan de tilegnede sig kliniske oplysninger. Oplysningerne hidrørte fra de journaler, som lægerne - som del af dagens arbejde - skulle gennemgå, og der var således ikke opstillet kriterier vedrørende patienternes antal eller type.

Observationerne blev udført som videounderstøttet tænke-højt-undersøgelse, som beskrevet af fx. Kushniruk et al. [91], men med en mere aktiv observatørrolle end klassisk tænke-højt-undersøgelse. Den i dette studie anvendte metode kan anskues som observation kombineret med interview. Den er følgelig blevet kaldt obser-view[92], og er blevet beskrevet som en dialog, hvor man - i forlængelse af observationen - sammen reflekterer over det observerede[92].

Formålet med observationerne var at kortlægge, hvor lægens opmærksomhed var rettet hen - hvilke kliniske oplysninger og hvilke dele af journalen var i fokus. Lægerne blev fra starten opfordret til at tænke højt, og under obser-view blev de, om nødvendigt, bedt om at forklare, hvad de gjorde.

Den journal, som anvendes på afdelingen (og i Region Hovedstaden i øvrigt) har været under udvikling i årevis og består aktuelt af både digitale og papir-baserede dele. Den har tidligere været beskrevet i forbindelse med videnskabelige arbejder; således har Bansler et al.[17] og Nøhr et al.[93] beskrevet, at regionens journal består af en række af papirbaserede og digitale dokumenter og databaser, hvis struktur er bestemt af, hvor og hvordan informationen er tilvejebragt - altså en fragmenteret og kildeorienteret samling af klinisk information.

I gennemgangen af videomaterialet blev der baggrund af lægernes udsagn foretaget en registrering af konsekutive kliniske oplysninger og journaldele - jf. eksempel i Tabel 13, side 67. De kliniske

\footnotetext{
9 Betegnelsen Bispebjerg og Frederiksberg Hospitaler er udtryk for ét hospital på to matrikler. Hospitalet er et af Region Hovedstadens fire akuthospitaler og betjener 416.000 borgere i Københavns og Frederiksberg Kommuner. Hospitalet er et universitetshospital og er akkrediteret efter internationale standarder og Den Danske Kvalitetsmodel.
} 
oplysninger, som en læge således beskrev i forbindelse med gennemgangen af en enkelt patient, blev afbildet i form af en mindmap - jf. eksempel i Figur 13, side 70.

\subsubsection{Resultater}

Studiet omfattede obser-views med i alt otte læger, som kontekstualiserede information om 36 patienter, hvilket resulterede i 10 timers video-optagelse.

\subsubsection{Journalen og lægernes anvendelse af den}

Journalen var - som beskrevet i tidligere arbejder - fragmenteret og kildeorienteret. De deltagende læger blev observeret at kontekstualisere information fra de kilder, som er anført i Tabel 11. De anførte journaldele udgjorde åbenlyst kun et udsnit af den samlede journal.

Tabel 11. Anvendte kilder

\begin{tabular}{|l|l|l|}
\hline \multicolumn{1}{|c|}{ Digitale } & \multicolumn{1}{|c|}{ Papirbaserede } & \multicolumn{1}{c|}{ Dialog } \\
\hline Oversigtstavle & Lægenotater (kontinuationer) & Dialog med klinisk mikrobiolog \\
Lægenotater (kontinuationer) & Mikrobiologiske prøvesvar & Røntgenkonference \\
Medicinliste & EKG & Dialog med sygeplejerske \\
Mikrobiologiske prøvesvar & EWS-skema & Dialog med patient \\
Biokemiske prøvesvar & Sygeplejenotater & Dialog med kollega \\
Billeddiagnostisk system & & \\
Telemetri, real-time & & \\
Telemetri, trend analyse & & \\
\hline
\end{tabular}

Overordnet udførte alle deltagende læger gennemgang af en patient på samme måde: Lægen læste de basale oplysninger på oversigtstavlen, hentede den papirbaserede dokumentation, loggede ind $\mathrm{i}$ det digitale informationssystem, og udførte en omfattende gennemgang af de forskellige kilde-sektioner. Efter en gennemgang af sygeplejenotaterne og/eller en dialog med den ansvarlige sygeplejerske, havde lægen en samtale med - og foretog en klinisk undersøgelse af - patienten. I det omfang lægen anså det nødvendigt, blev de indsamlede oplysninger suppleret ved yderligere gennemgang af journalens forskellige dele og eventuel dialog med eksterne specialister. Endelig orienterede lægen mundtligt den ansvarlige sygeplejerske om fattede beslutninger, som desuden blev dokumenteret dels gennem direkte interaktion med de digitale journaldele, dels gennem diktat af et journalnotat (en kontinuation).

De oplysninger, som lægerne i dette studie kontekstualiserede, stammede fra 36 patienter. Udover hvad lægerne udtrykte i tænke-højt-undersøgelsen, blev der ikke registreret oplysninger om patienterne. På dette grundlag kan de 36 patienter karakteriseres, som angivet i Tabel 12: 
Tabel 12. Patienterne

\begin{tabular}{|l|c|c|}
\hline \multicolumn{2}{|c|}{} & De fem mest nævnte diagnoser \\
\hline Antal patienter & 36 & Demens \\
Mænd / kvinder & $14 / 22$ & Diabetes \\
Pneumoni \\
Alder, gennemsnit & 70,5 år & Alkohol-misbrug \\
\hline Diagnoser, gennemsnit & 3,6 & Diarré \\
\hline
\end{tabular}

I langt de fleste tilfælde gennemgik lægerne én journaldel ad gangen - altid startende med oversigtstavlen og kontinuationerne. Tidsmåling og evaluering af journalens usability var ikke en del af dette studie, men det var åbenlyst, at lægernes anvendelse af journalen ikke er uproblematisk. Således blev der i studiet observeret eksempler på

- tidskrævende login for at få adgang til den digitale journal

- tab af forbindelse til digital journaldel med krav om fornyet login

- krav om repeteret angivelse af patientdata (datalogisk kontekst) ved skift mellem digitale journaldele. Dette ofte efterfulgt af tidskrævende fremfinding af journaldelens oplysninger om den aktuelle patient.

Der blev observeret adskillige situationer, hvor skiftet mellem forskellige dele af journalen gav anledning til spildtid, og det var i disse situationer tydeligt, at interaktionen med de digitale systemer og den påtvungne spildtid stressede lægerne. Det skal i den forbindelse også nævnes, at samtlige observerede journalgennemgange foregik ved arbejdsstationer med en enkelt skærm, og det var således kun muligt for lægen at navigere og se én digital journaldel ad gangen.

\subsubsection{Lægernes kontekstualisering af klinisk information}

Under gennemgang af en patient skiftede lægens opmærksomhed fra emne til emne. Med den video-understøttede obser-view-metode var det muligt at registrere disse opmærksomhedsskift som en sekvens af emner, udtrykt med lægens egne ord. Det var desuden muligt samtidigt at registrere den kilde til information, hvorfra lægen kontekstualiserede oplysningerne. Et stykke af en sådan sekvens er vist i Tabel 13:

Tabel 13. Fokus-kilde-sekvens (eksempel fra patient $\# 008^{10}$ )

\begin{tabular}{|c|l|l|l|}
\hline Tid & \multicolumn{1}{|c|}{ MikroBio } & KlinKem & EWS-skema \\
\hline 05:20 & (åbner system) & & \\
\hline $06: 00$ & venuler & & \\
\hline
\end{tabular}

\footnotetext{
${ }^{10}$ Kontekstualiseringen af Patient \#008 er anvendt som gennemgående eksempel i beskrivelsen af dette studie. Dette fordi kontekstualiseringsforløbet er typisk for de observerede patienter med den undtagelse, at det er mere overskueligt, fordi patient \#008 kun har en enkelt problemstilling, og i øvrigt er helt rask. Deri adskilte hun sig fra de fleste patienter, som havde flere konkurrerende lidelser og et mere kompliceret kontekstualiseringsforløb.
} 


\begin{tabular}{|c|c|c|c|}
\hline Tid & MikroBio & KlinKem & EWS-skema \\
\hline & afføringsprøver & & \\
\hline \multirow[t]{2}{*}{ 06:10 } & clostridier & & \\
\hline & $\begin{array}{l}\text { clostridie-prøver, ikke } \\
\text { svar }\end{array}$ & & \\
\hline $06: 43$ & $\begin{array}{l}\text { venuler er foreløbigt ne- } \\
\text { gative }\end{array}$ & & \\
\hline $06: 50$ & (lukker system) & (åbner system) & \\
\hline $07: 23$ & & levertal & \\
\hline \multirow[t]{2}{*}{ 07:51 } & & $\begin{array}{l}\text { leukocytter tidligere } \\
\text { lille fald }\end{array}$ & \\
\hline & & leukocytter stigende & \\
\hline \multirow[t]{2}{*}{ 08:02 } & & CRP ikke faldende & \\
\hline & & $\begin{array}{l}\text { ikke overbevisende ef- } \\
\text { fekt af behandling }\end{array}$ & \\
\hline 08:18 & & & $\begin{array}{l}\text { "værdier", henter sgpl- } \\
\text { papirer }\end{array}$ \\
\hline \multirow[t]{2}{*}{ 08:49 } & & & $\begin{array}{l}\text { feber ( temperatur ) } \\
\text { svingende }\end{array}$ \\
\hline & & & $\begin{array}{l}\text { ikke overbevisende ef- } \\
\text { fekt af behandling }\end{array}$ \\
\hline 09:04 & & & $\begin{array}{l}\text { EWS (vitale værdier) } \\
\text { OK }\end{array}$ \\
\hline
\end{tabular}

Tabel 13 viser som eksempel en sekvens på knap fire minutter hvor en læge kontekstualiserer kliniske oplysninger vedrørende en patient med gastroenterit. Vandret er vist de informationskilder, som lægen benyttede i dette tidsrum, lodret vises fortløbende tid. I skemaet er anført de emner, som lægen gav udtryk for at have opmærksomheden henledt på - diagnoser, medicin, organsystemer, interventioner, mm. Registrerede emner er markeret fed blå.

Som anført var der en tydelig tendens til, at de observerede læger "læste journalen" på en kildeorienteret måde - fx. kontinuationer, medicinliste, blodprøve-svar, mikrobiologi-svar, røntgen-svar, sygeplejenotater. Rækkefølgen, hvori disse journaldele blev anvendt, varierede lidt, men det overordnede mønster med kildeorienteret "blok-læsning" var tydeligt ved alle patienter.

Nogle læger førte undervejs en håndskrevet liste over emner, som for den aktuelle patient skulle belyses nærmere, eller som krævede en form for beslutning; andre holdt oplysningerne i hukommelsen. Der blev observeret eksempler på, at emner blev glemt undervejs.

Ved at plotte registrerede emner over tid mod journalens dele var det muligt at afbilde lægens "vej gennem journalen": 


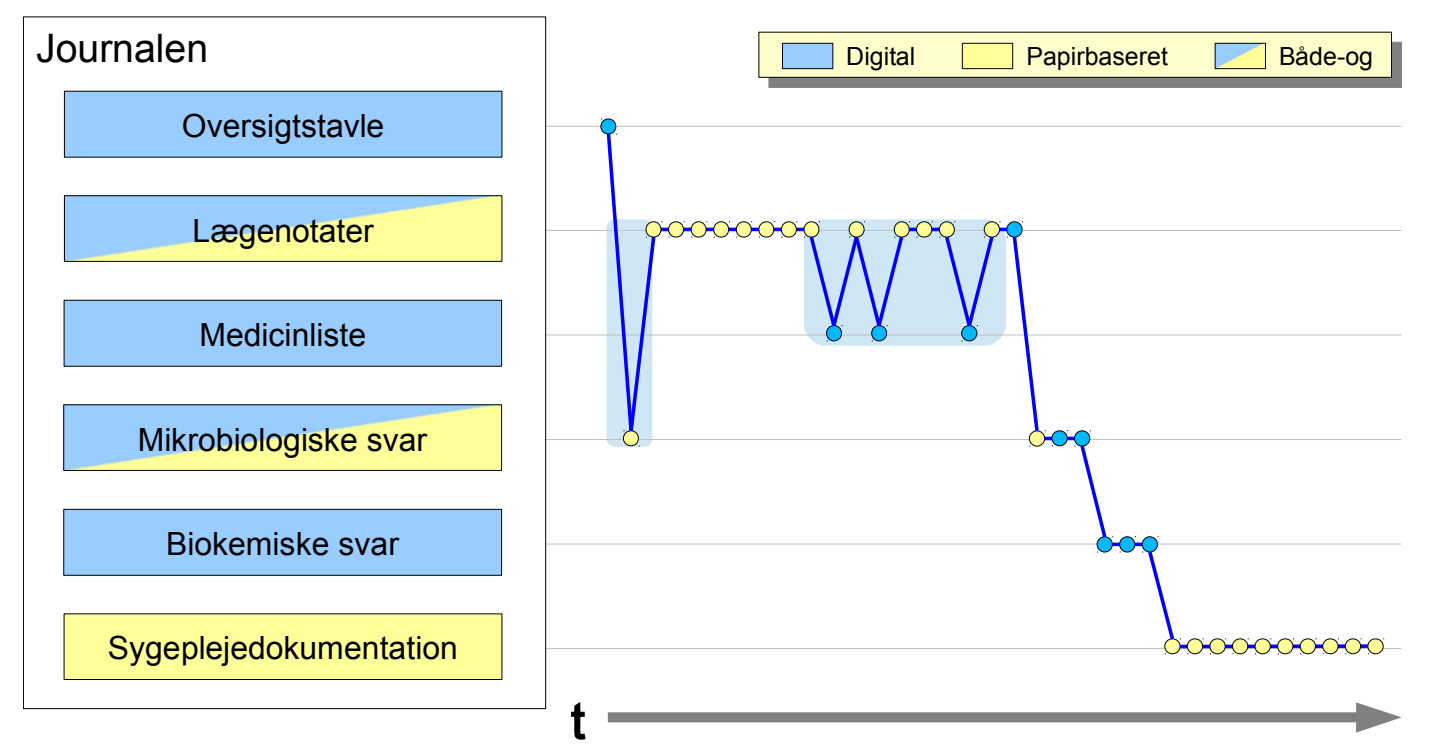

Figur 12. Kontekstualisering anskuet i forhold til journalens struktur (eksempel fra patient \#008). Hvert punkt er et registreret emne. Split-attention (omtalt senere) er markeret med lys-blå baggrund.

Figur 12 viser, hvordan en læge over tid benytter en række af journalens dele til at kontekstualisere kliniske oplysninger om en patient. Hvert punkt repræsenterer et registreret emne (jf. Tabel 13). Figuren demonstrerer, hvordan lægen overordnet tilgår journalens dele sekventielt, men viser også eksempler på, at lægen skifter frem og tilbage mellem journaldele.

\subsubsection{Den klinisk-logiske informationsstruktur}

Ved at samle alle emner, som over tid var registreret i forbindelse med gennemgang af en patient, var det muligt at tegne et billede - en mindmap - af den informationsstruktur, hvori lægen havde samlet den kontekstuelle information. Denne struktur blev opfattet som lægens klinisk-logiske informationsstruktur for den givne patient. Et eksempel er vist som Figur 13: 


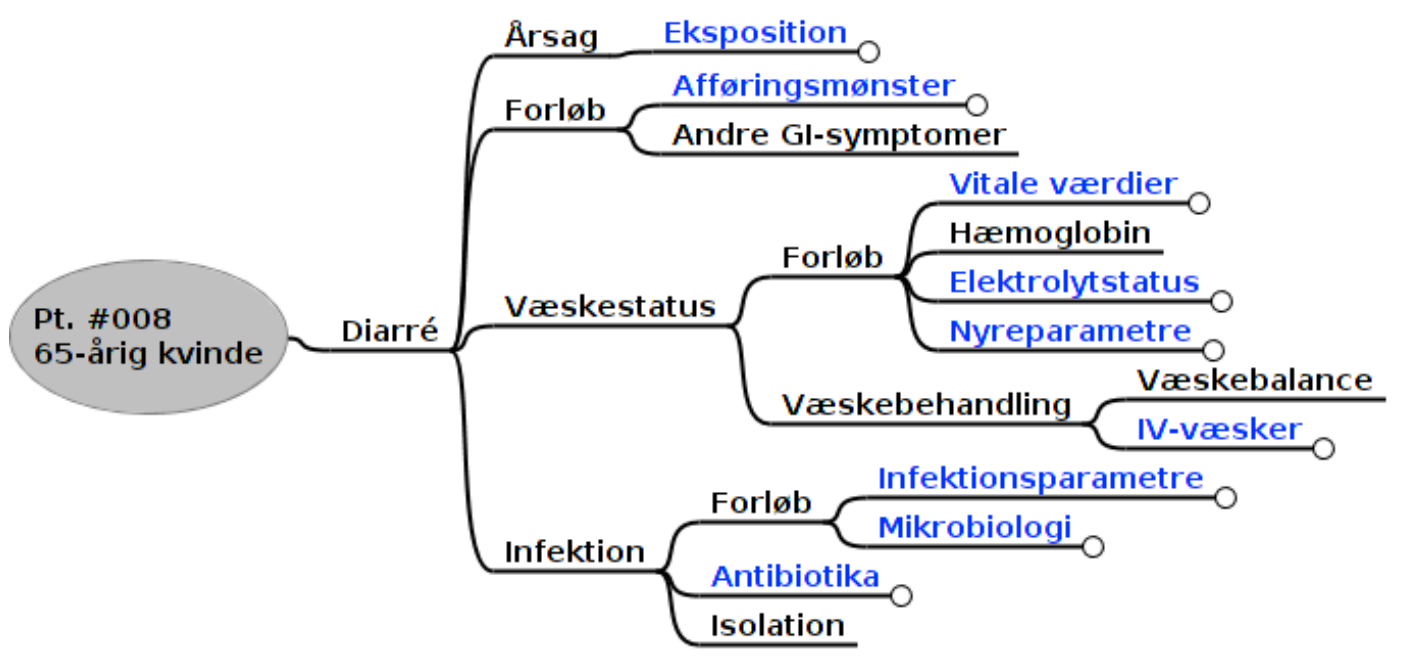

Figur 13. Klinisk-logisk informationsstruktur (eksempel fra patient \#008). Flere knuder (fx. Eksposition, Vitale værdier) har yderligere underliggende knuder, men er her vist som kollaberede og farvet blå.

Figur 13 viser et eksempel på kliniske oplysninger i en klinisk-logisk struktur. Patienten i eksemplet har (atypisk!) kun én diagnose og oplysningerne har derfor kunnet ordnes i en ganske simpel struktur. Eksemplet er yderligere forsimplet ved, at nogle af træstrukturens knuder er vist kollaberet - således er 22 terminale knuder her kun symboliseret ved mere overordnede knuder. I Bilag 5 er vist den fuldt udfoldede struktur for denne patient sammen med nogle yderligere eksempler på klinisklogisk informationsstruktur fra dette studie.

Kontekstualisering af oplysninger var hos nogle af patienterne mere kompleks, som illustreret i Eksempel 9:

Eksempe1 9. Kompleks kontekstualisering (eksempel fra patient \#091)

90-årig kvinde 1) er bevidsthedspåvirket, 2) har lavt blodtryk og påskyndet puls. Lægen overvejer om patienten 3) har sepsis og/eller 4) er dehydreret. De fire oplysninger udgør gensidigt kontekst for hinanden, idet:

- påvirket bevidsthed kan være forårsaget af sepsis, dehydrering eller lavt blodtryk

- dehydrering kan være en følge af påvirket bevidsthedsniveau eller sepsis

- lavt blodtryk og påskyndet puls kan være en følge af sepsis eller dehydrering

\subsubsection{Informationsstruktur - $\mathrm{i}$ journalen og hos lægen}

Hvor Figur 12, side 69, illustrerede, hvordan lægers kontekstualisering over tid relaterer sig til forskellige strukturelle dele af journalen, er det på nedenstående Figur 14 illustreret, hvordan samme kontekstualisering relaterer sig til forskellige dele af lægens klinisk-logiske informationsstruktur: 


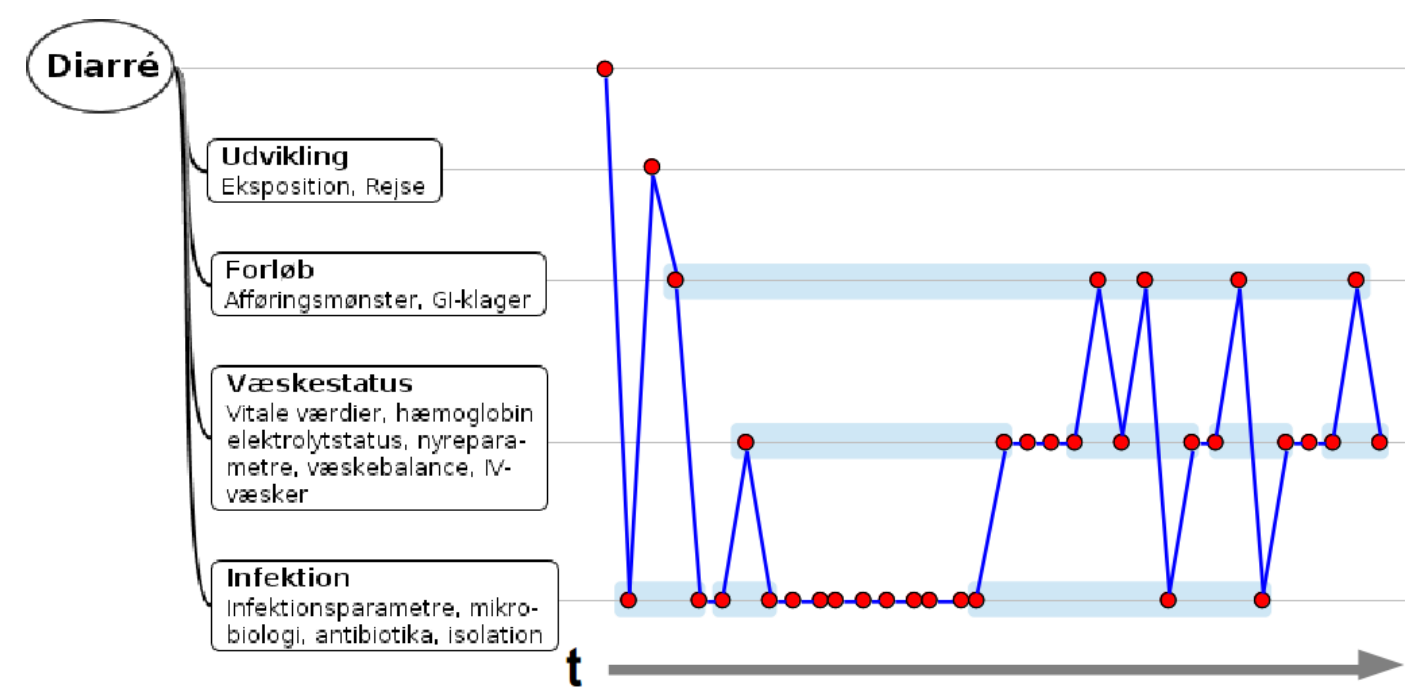

Figur 14. Kontekstualisering anskuet i forhold til den klinisk-logiske informationsstruktur (eksempel fra patient \#008). Hvert punkt er et registreret emne. Split-attention (omtalt senere) er markeret med lys-blå baggrund.

På Figur 14 er (forsimplet) afbildet den informationsstruktur, som mere detaljeret blev vist i Figur 13. Figur 14 viser hvordan lægens opmærksomhed under gennemgang af journalen skifter mellem forskellige overordnede dele af den klinisk-logiske informationsstruktur.

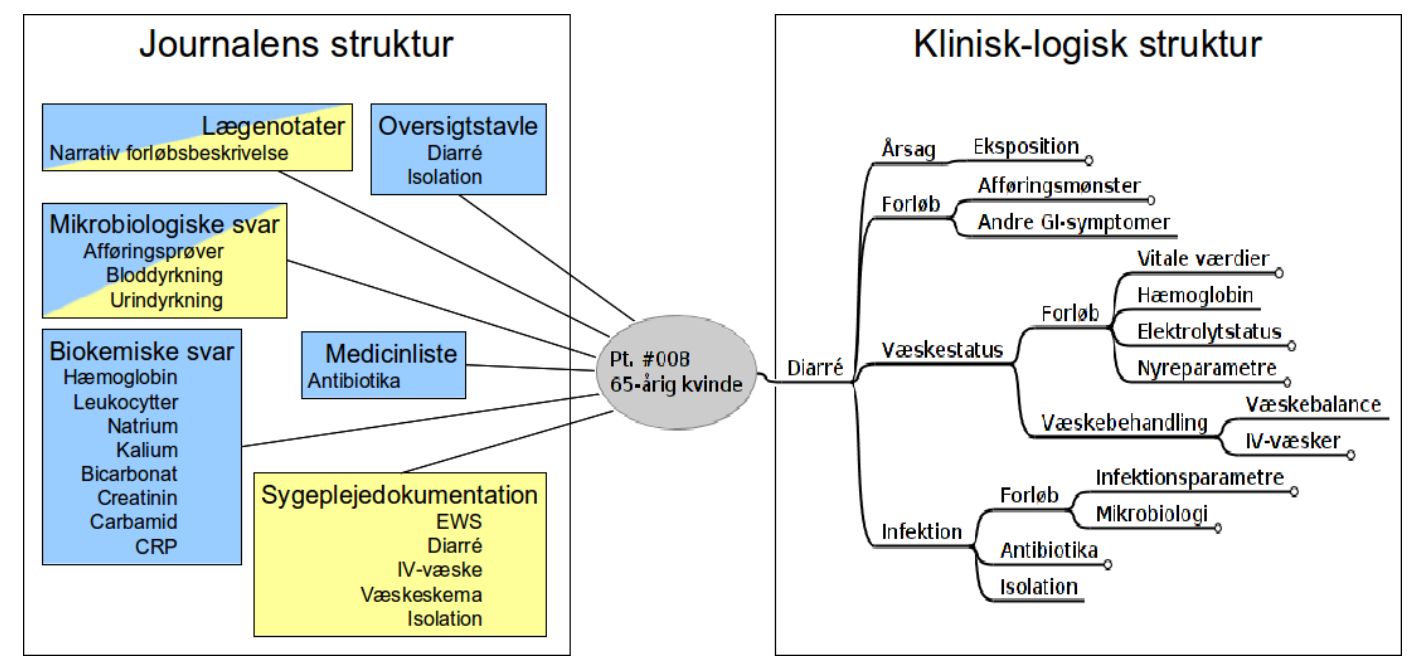

Figur 15. To forskellige informationsstrukturer

Man kan sammenligne de to informationsstrukturer - journalens og den klinisk-logiske. Stadig med patient \#008 som eksempel er en sådan sammenligning illustreret på Figur 15, der både viser den struktur, hvori journalen blev "læst" (venstre side) og den klinisk-logiske struktur, hvori lægen kontekstualiserede de kliniske oplysninger (højre side). Som det fremgår af illustrationen, er der åbenlys forskel på de to informationsstrukturer, og eksemplet er typisk for observationerne, hvor ingen kontekstualisering skete $\mathrm{i}$ henhold til journalens informationsstruktur. 


\subsubsection{Findes der generelle klinisk-logiske informationsstrukturer?}

Med henblik på undersøge om klinisk information i højere grad kan gøres tilgængelig på en måde, der modsvarer den klinisk-logiske informationsstruktur, blev det forsøgt at identificere mønstre i de oplysninger, som lægerne havde kontekstualiseret.

Måden, hvorpå studiet var designet, gjorde, at de indgående patienter ${ }^{11}$ var uselekterede, og derfor ikke sammenlignelige. Alligevel var det muligt på tværs af læger og patienter at identificere blokke af oplysninger, som i henhold til de observerede klinisk-logiske informationsstrukturer med fordel burde kunne kontekstualiseres i sammenhæng.

Tabel 14. Eksempler på identificerede kontekstualiseringsblokke

\begin{tabular}{|cc|}
\hline KOL, forløb & Infektion \\
Vitale værdier & Ventilation \\
Væskestatus & Ekspektoration \\
Infektionsparametre & Kardiel arytmi \\
\hline
\end{tabular}

I Bilag 6 er vist eksempler på sådanne kontekstualiseringsblokke. De er indsamlet på tværs af læger og patienter - dvs. de udgør oplysninger, som flere læger havde kontekstualiseret i sammenhæng. Disse blokke opfattes her som kontekstualiseringens byggesten - de oplysninger, som en læge - med opmærksomheden henledt på et givet emne - med stor sandsynlighed vil kontekstualisere i sammenhæng.

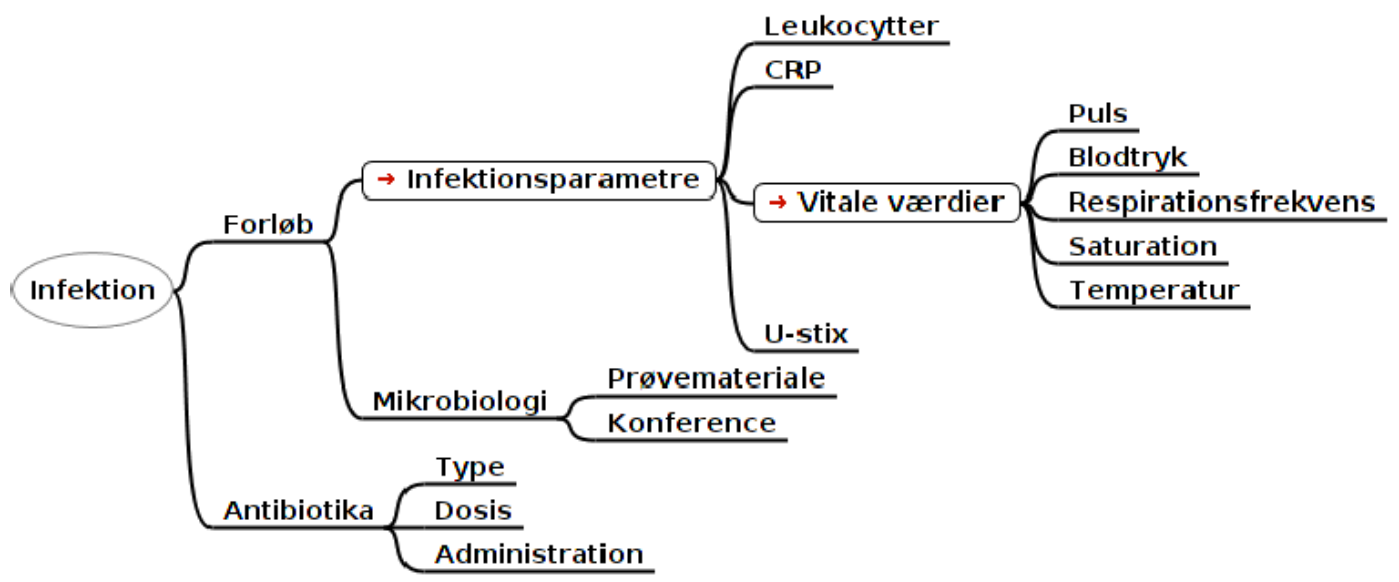

Figur 16. Kontekstualiserede oplysninger ved infektion

Figur 16 illustrerer denne opfattelse af byggesten og kontekstualisering: For en række af de indgående patienter, var infektion en problematik, som lægerne forholdt sig til - hvad enten patienten havde lungebetændelse, gastroenterit, erysipelas, pankreatit, mm. Det var et gentaget mønster, at

\footnotetext{
${ }^{11}$ Når der her anvendes udtrykket "indgående patienter" skal det understreges, at der hermed menes de patienter, som var genstand for de observerede lægers kontekstualisering. Observation af patienter har ikke været en del af denne undersøgelse.
} 
lægerne dels kontekstualiserede oplysninger, som beskrev infektionens forløb - infektionsparametre og evt. mikrobiologiske fund - og behandlingen med antibiotika. Lægernes interesse for infektionsparametre var ikke begrænset til patienter med kendt infektion - infektionsparametre var noget som i en eller anden udstrækning indgik i kontekstualiseringen for hovedparten af patienter. I en lang række sammenhænge, men altså også som en del af infektionsparametre, blev vitale værdier kontekstualiseret.

\subsubsection{Diskussion}

\subsubsection{Obser-view som metode}

I dette delstudie var formålet at undersøge, hvilke oplysninger lægerne kontekstualiserede, og hvor de hentede dem. Anskuet som en usability-undersøgelse af journalen syntes det umiddelbart nærliggende valg af metode at være videounderstøttet tænke-højt-undersøgelse, som beskrevet af Kushniruk et al. [91] og udført i flere arbejder, fx. [51,56,61].

Imidlertid har Patel et al.[52] beskrevet, hvordan klassisk tænke-højt-undersøgelse anvendt til at vurdere lægers måde at tænke på har resulteret i utilstrækkelige observationer:

When attempting to identify the directionality of reasoning of the subjects, we found that we were unable to use the straightforward problem- solving paradigm because standard think-aloud techniques yielded extremely sparse protocols.[52]

Der blev derfor valgt en ikke-klassisk variant af tænke-højt-undersøgelse, nemlig obser-view, der af Kragelund[92] er beskrevet som en kombination af observation og interview:

Obser-view is understood to mean a dialogue between research participant and researcher in which they reflect on experiences they have had during the researcher's observation of the participant[92].

Denne metode kan opfattes som en tænke-højt-undersøgelse, hvor observatøren har en mere aktiv rolle - det, som Hertzum et al.[94] har beskrevet som "relaxed thinking aloud ":

Relaxed thinking aloud: Participants performed the tasks while thinking out loud and the experimenter intervened with questions asking participants for explanations and comments. This condition ... corresponds to how thinking aloud is commonly employed in the context of usability evaluation. [94]

Hertzum et al. beskriver, hvordan denne metode lægger større beslag på observandens mentale kapacitet, og hvordan observatøren gennem sin påvirkning ændrer det observerede: 
The relaxed approach to thinking aloud threatens the validity of the method and indicates that this approach, common in practical usability evaluation, may not be the authoritative yardstick it is often assumed to be. [94]

Der er ved tænke-højt-undersøgelse altid den usikkerhed, at observanden kun ekspliciterer nogle aspekter, og måske mest sådanne, som i særlig grad fylder i observandens bevidsthed - fx. det svære, det anderledes. Desuden er der - jf. ovenstående citat - ingen tvivl om, at min aktive interaktion med observanderne har påvirket observationerne - spørgsmålet er i højere grad, i hvilken retning observationerne er blevet forskudt. Der er tre væsentlige årsager til at antage, at den bias, jeg har påført observationerne, tenderer mod, at der registreres flere og mere detaljerede kliniske oplysninger:

- I modsætning til en række laboratorieundersøgelser af lægers kognitive processer, fx. $[52,56,95]$ er der her tale om et in-vivo studie. De kliniske oplysninger, som lægerne kontekstualiserede, var ikke baseret på opdigtede eller udvalgte cases, men dannede grundlag for reelle beslutninger vedrørende rigtige patienter. Der er således rimelig sikkerhed for, at lægerne ikke som konsekvens af obser-viewet har undladt væsentlig kontekstualisering.

- Den situation, som de afholdte obser-views udgjorde, lå tæt på en for læger almindelig undervisningssituation, hvor man følges med en mere erfaren kollega, som løbende gør rede for sine overvejelser. Det var en tydelig rolle, som både jeg og de observerede læger let faldt ind i - det skete således flere gange, at jeg fik forklaret generelle farmakologiske og patologiske mekanismer, som jeg ikke havde spurgt ind til. Det er muligt - måske endda sandsynligt - at lægerne på kanten af en underviser-rolle har ønsket at demonstrere den faglige spændvidde ved at inddrage information og uddybe aspekter, som de normalt ville behandle mere overfladisk.

- Og endelig skal det bemærkes, at jeg selv er en erfaren læge, og at jeg derfor i obser-viewsituationen har kunnet spørge ind til de anvendte oplysninger på en måde, som en lægmand ikke ville have kunnet. Dette bidrager til, at gøre det indsamlede rå-materiale mere detaljeret, men betyder også, at jeg - ved at vise min forståelse for den mentale proces - får yderligere vanskeligt ved ikke at påvirke situationen.

Sammenfattende er det min oplevelse, at video-understøttet obser-view af lægers anvendelse af journalen er en metode, som er velegnet til kortlægning af, hvilke oplysninger læger kontekstualiserer, omend man skal være opmærksom på, at metoden rummer et stort potentiale for observatørafhængighed, og at resultatet afhænger af observatørens kendskab til domænet.

\subsubsection{Den registrerede kontekstuelle information}

Sammenlignet med registreringsmetoden anvendt i Bispebjerg-studiet (afsnit 8.2, side 50) var to forhold bemærkelsesværdige: Produktionskontekstuel klinisk information havde en langt mindre fremtrædende rolle, og der blev observeret kontekstuel information med en højere kompleksitetsgrad. Der er formodentlig flere årsager hertil, men den mest betydningsfulde årsag anses at være den ændrede situation - både i forhold til de observerede læger og til observationsmetoden: 
I Bispebjerg-studiet optrådte den observerbare kontekstuelle information som dialog; omstændigheder vedrørende de enkelte oplysninger var ikke nødvendigvis åbenlyse, og blev derfor ofte eksplicit efterspurgt. Dette i modsætning til det aktuelle delstudie, hvor den observerbare kontekstuelle information optrådte som monolog på grundlag af et journalmateriale med alle de metadata og kildehenførbare oplysninger, som dette indebærer. Denne forskel antages at være årsagen til, at produktionskontekstuel klinisk information næsten ikke optrådte i dette studie, og da hovedsageligt som et spørgsmål om, hvornår prøver var taget og hvornår svar var ankommet.

Desuden var registreringen af kontekstuel information i Bispebjerg-studiet baseret på sammenhængen mellem sundhedsaktivitet og kontekstuel klinisk information, og selve registreringsmetoden var derfor ikke velegnet til at afdække komplekse kontekstuelle relationer - fx. af den type, som er anført i Eksempel 9, side 70, og som var tydelige under anvendelse af obser-view.

\subsubsection{Mindmapping som metode}

Det materiale, som blev indsamlet med obser-view, blev efterfølgende behandlet dels med en ekstraktion af lægernes ekspliciterede fokuspunkter, dels med en optegning af oplysningerne i en mindmap.

Ekstraktionen foregik som illustreret i Tabel 13, side 67 - dvs. de fokuspunkter, som lægen nævnte blev registreret under anvendelse af lægens egne ord. I takt med ekstraktionen blev fokuspunkterne indført i en mindmap, som således udviklede sig løbende. Strukturen i mindmappen blev skabt som funktion af flere faktorer:

- Den helt overordnede struktur var givet af patientens kendte eller formodede diagnoser/problemstillinger, som tydeligt udgjorde overskrifterne for lægens arbejde.

- I flere tilfælde var strukturen åbenlys selvom lægen ikke ekspliciterede den. fx. hos en patient (Patient \#002) med svær demens og lungebetændelse blev information om manglende sprog og fejlsynkning grupperet under demens, og information om arteriepunktur og behov for sugning blev grupperet under lungebetændelse.

- Lægerne anførte undervejs som en del af dialogen, hvordan de betragtede informationen. Et udsagn som fx. "... og når man ser på forløbet ..." samtidigt med, at der er fokus på infektionsparametre, er taget til indtægt for at mappe infektionsparametre under forløb.

- I en række tilfælde var den gruppering af oplysninger, som lægen anførte, en følge af observiewets spørgsmål. fx. en dialog som: "Og her ser du på elektrolytterne?", "Ja og på nyreparametrene." gav i analysefasen anledning til en gruppering, hvor elektrolytstatus blev adskilt fra nyreparametre.

- En del struktur har jeg selv tilføjet på grundlag af mit kendskab til det sundhedsfaglige domæne. 
- Endelig var der eksempler på kontekstualisering, som ikke kunne indpasses i en struktur baseret på patientorienterede problemstillinger, fordi de blev udført som del af lægernes generelle kvalitetssikring. Den slags kontekstualisering optrådte efter udsagn, som fx. "Og så tjekker jeg altid lige op på deres medicin...", eller "... og så ser jeg, om der ellers er kommet nogle blodprøver...".

Som det fremgår af de ovenstående punkter, har jeg både som observatør og analysator udøvet indflydelse på den afbildede klinisk-logiske informationsstruktur. Og selvom jeg undervejs har været opmærksom på at undgå bias og har bestræbt mig på at registrere de kontekstualiserede emner ordret, er det relevant at rejse spørgsmålet om, hvor meget af den fundne informationsstruktur som faktisk er den observerede læges. Denne svaghed ved undersøgelsen burde have været imødegået ved en form for kvalitetskontrol - fx. ved at lade den observerede læge forholde sig til den fundne informationsstruktur eller ved at lade yderligere bedømmere foretage en parallel analyse af videomaterialet. Men selv i lyset af observatør-bias er der ingen tvivl om, at lægernes klinisk-logiske informationsstrukturer er klart afvigende fra strukturen af den anvendte journal.

\subsubsection{Hvilken betydning har forskelle i informationsstruktur?}

Det blev i studiet bemærket, at der var en tydelig tendens til, at lægerne "læste journalen" på en kildeorienteret måde - én journaldel ad gangen. Det er muligvis begrundet i professionel tradition, og det forekommer i høj grad hensigtsmæssigt i et tidsorienteret perspektiv, når man - som i dette studie - anvender en journal, hvor skift mellem journaldele medfører spildtid og udløser stress. Set i det lys, er observationen helt $\mathrm{i}$ overensstemmelse med observationer gjort af Kannampallil et al. [61], som bemærker, at:

The information seeking process was driven by the socio-technical organization within the environment. [61]

Imidlertid forekommer det $\mathrm{i}$ et kvalitets- og sikkerhedsorienteret perspektiv mindre hensigtsmæssigt, idet den fuldstændige mangel på sammenhæng mellem journalens informationsstruktur og de i studiet fundne klinisk-logiske strukturer som konsekvens har, at lægerne under kontekstualiseringen enten skal skifte mellem flere journaldele for at få et emne belyst, eller skal holde et emne i hukommelsen indtil de relevante journaldele er gennemgået. Dette kaldes split-attention:

Split-attention occurs when persons are required to split their attention between two or more mutually dependent sources of information (e.g. text and diagram), which have been separated either spatially or temporally. [96]

Split-attention udgør en kognitiv belastning[96,97],og er beskrevet som en belastning for klinisk arbejde og en medvirkende årsag til medicinske utilsigtede hændelser[61,98]. 
Forekomsten af split-attention er i dette studie illustreret i Figur 12 og 14, henholdsvis side 69 og 71. Figurerne er her gentaget som miniaturer:
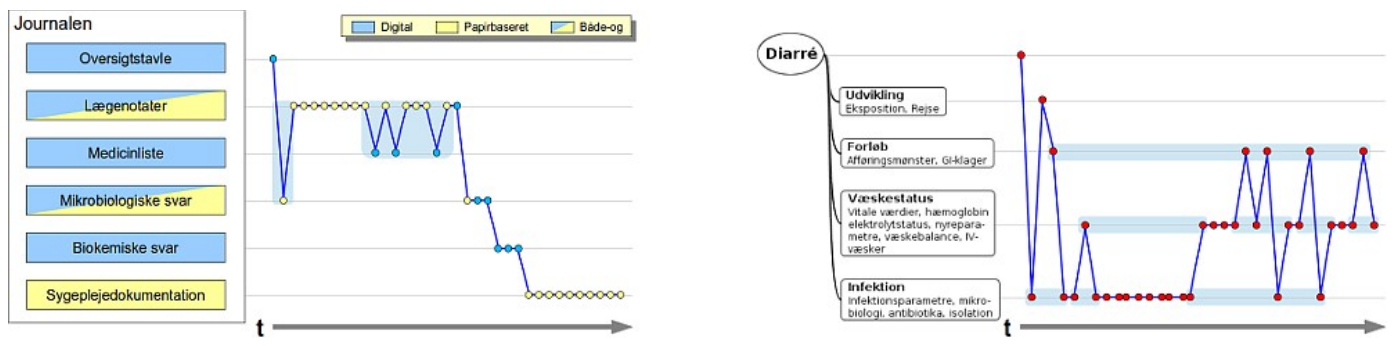

Figur 17. Miniaturer af foregående Figurer $12 \mathrm{og}$ 14. Blå felter viser forekomsten af spatial og temporal split-attention.

Selvfølgelig må man altid forvente en vis grad af split-attention i forbindelse med kontekstualisering af information, der - som klinisk information - kan underkastes fortolkning, og hvis implikationer omfatter gensidig afhængighed. Man kunne således forvente, at lægerne med et givet klinisk emne i fokus "bladrede" frem og tilbage i journalen for at få emnet belyst. Den slags problemorienteret spatial split-attention forekom, men langt hovedparten af den observerede split-attention blev set $\mathrm{i}$ forbindelse med:

- kontrol af, at informationssystemets oplysninger er konsistente (spatial split-attention). Et karakteristisk eksempel er illustreret på Figur 12, side 69, hvor lægen skifter frem og tilbage mellem lægenotater og medicinliste for at kontrollere, at antibiotika-behandlingen er korrekt beskrevet. Et andet hyppigt forekommende eksempel var kontrol af konsistens mellem papirbaserede og digitale lægenotater.

- ophobning af oplysninger under sekventiel tilgang af journalen (temporal split-attention), som illustreret på Figur 14, side 71. Dette blev observeret i forbindelse med samtlige patienter.

Sammenfattende er der i dette studie observeret ganske betydelig forekomst af split-attention hos lægerne. Dette ses som en potentiel risiko, og der blev i studiet faktisk observeret situationer, hvor lægerne undervejs glemte emner, som de tidligere havde anført til opfølgning. Journalens funktionalitet og struktur synes at være en meget væsentlig årsag til den observerede split-attention, og det konkluderes på dette grundlag, at den anvendte journal er suboptimal i forhold til lægers kontekstualisering af kliniske oplysninger.

\subsubsection{Generaliserede klinisk-logiske informationsstrukturer}

Påvisningen af, at journalens struktur er en væsentligt medvirkende årsag til split-attention hos lægerne, gjorde det yderligere sandsynligt, at man kan understøtte lægers kontekstualisering ved at gøre klinisk information tilgængelig i en form, der modsvarer lægernes interne strukturering af klinisk information. 
Selvom studiets design ikke omfattede kriterier for hvilke patientgrupper de indgående læger beskæftigede sig med, var det muligt at identificere oplysninger, som flere læger kontekstualiserede i sammenhæng. Eksempler på sådanne kontekstualiseringsblokke er angivet i Bilag 6. Den kontekstualiseringsblok, som i studiets materiale trådte tydeligst frem, bestod af oplysninger, som vedrørte infektion - se evt. Figur 16, side 72. Mange af de indgående patienter var manifest eller mistænkt inficerede, og de deltagende læger udviste stor ensartethed i deres måde at anskue oplysningerne. Der er ingen tvivl om, at man med en lignende undersøgelse på en anden afdeling - lungemedicin, ortopædkirurgi, anæstesi - havde fundet andre kontekstualiseringsblokke, og fundene i dette studie skal derfor kun tages som eksempler på, at det er muligt at identificere og udtrykke klinisk-logiske informationsstrukturer, som i et vist omfang kan generaliseres på tværs af læger og patienter.

Nedenstående Figur 18 anskueliggør den reduktion i split-attention, som et informationssystem baseret på lægers kontekstualisering kan stille i udsigt:

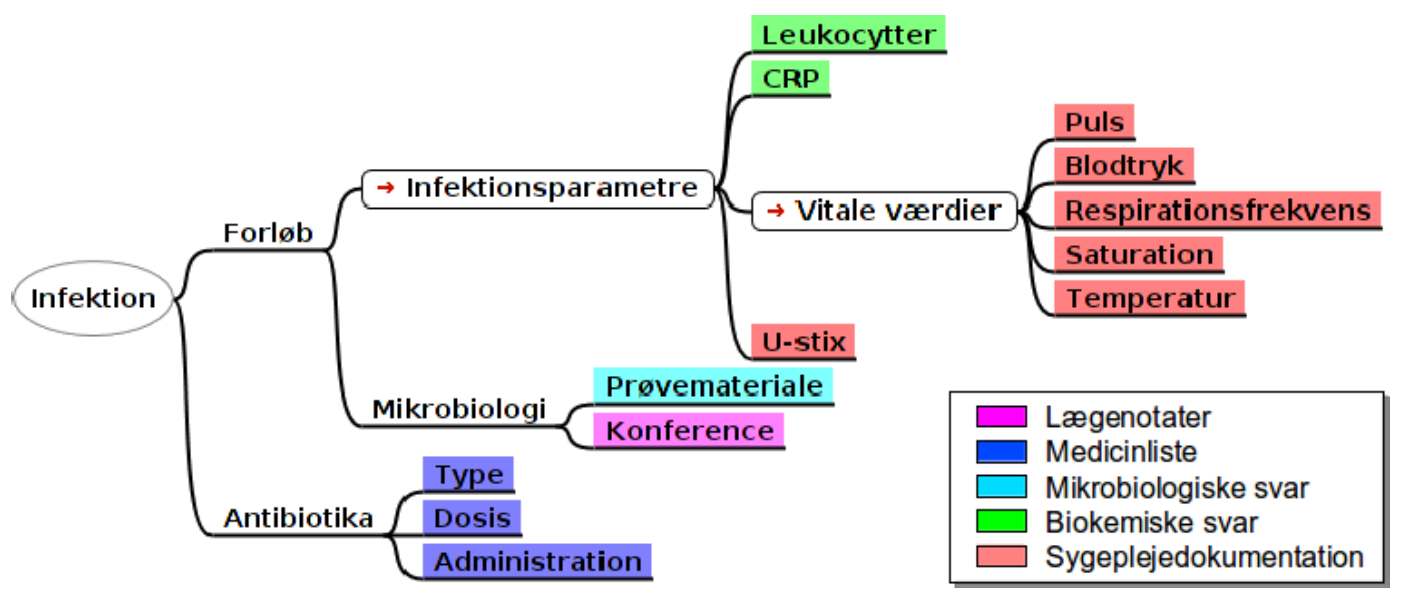

Figur 18. Journaldele med infektionsrelaterede oplysninger.

På Figur 18 er det - med udgangspunkt i den identificerede kontekstualiseringsblok vedrørende infektion - vist, hvor i den aktuelle journal man skal finde de forskellige informationer. Figuren illustrerer, at man ved at stille infektionsrelaterede oplysninger til rådighed i en samlet kontekstualiseringsblok, vil kunne spare læger for at skulle søge, finde og samle oplysningerne i op til fem forskellige journaldele.

\subsubsection{Kontekstualiseringsblokke vs. arketyper, templates og SFI}

Idéen om, at beskrive blokke af klinisk information, som har indbyrdes kognitiv sammenhæng, er ikke ny. Flere initiativer har arbejdet med konceptet - fx. openEHR's arketype-baserede templates[99], HL7's CDA-templates[100], NHS' clinical content[101] og det hjemlige SFIarbejde[21][20]. I nedenstående Figur 19 og 20 er vist eksempler på openEHR-templates og SFI: 


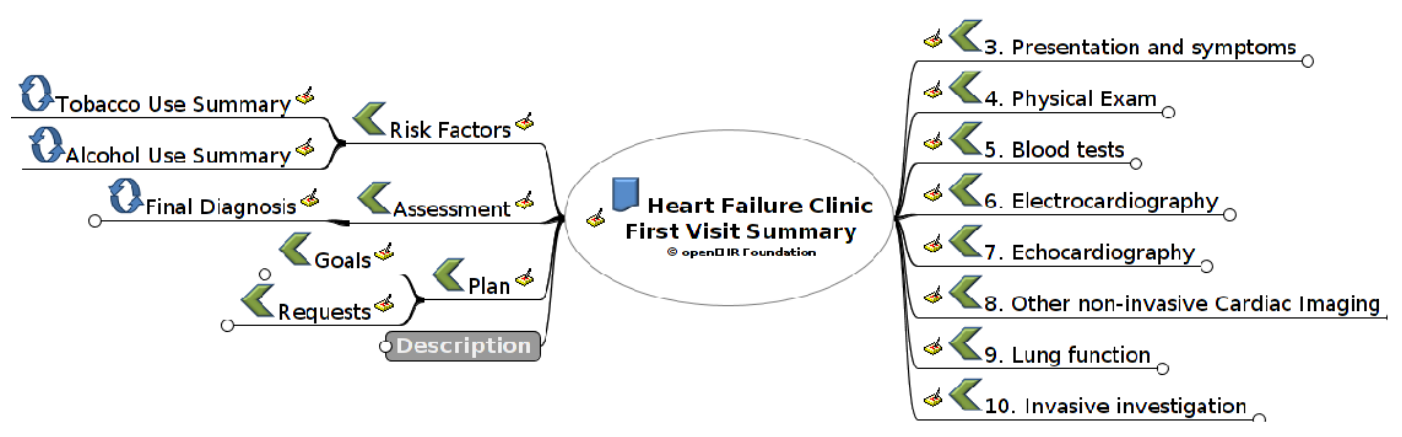

Figur 19. Template fra openEHR. Samler relevante data med henblik på dokumentation af initial kontakt med en patient med hjertesvigt.

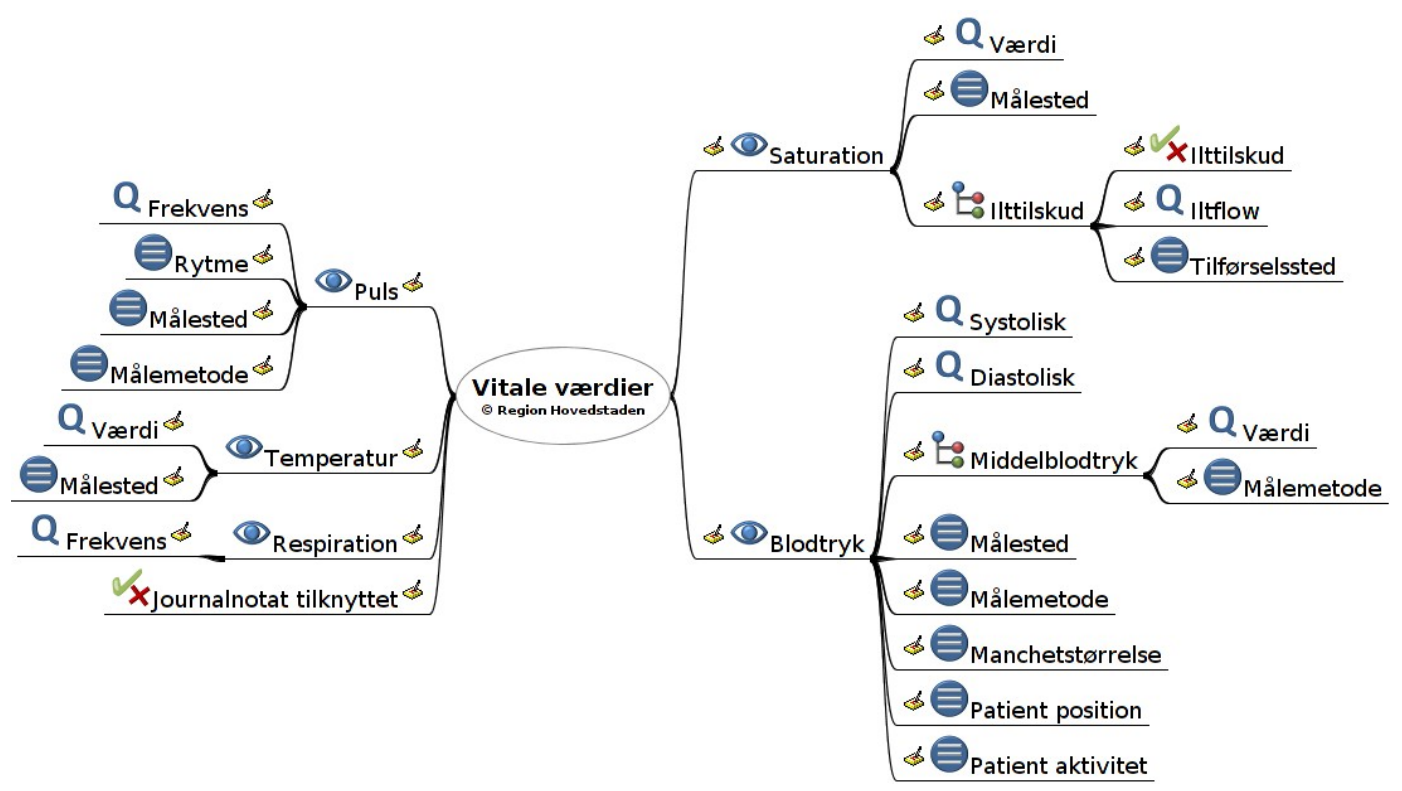

Figur 20. Standarddokumentation fra Region Hovedstadens SFI. Samler relevante data med henblik på registrering af vitale værdier.

Imidlertid adskiller de kontekstualiseringsblokke, som er beskrevet i de foregående afsnit, sig fra de ovennævnte initiativer på to væsentlige punkter - måden, hvorpå de er tilvejebragt, og formålet med deres anvendelse:

- Hvor de kontekstualiseringsblokke, som er identificeret i denne afhandling, er baseret på invivo observation af lægers kontekstualisering, er de ovennævnte organisationers tiltag alle baseret på workshoparbejde mellem klinikere og eksperter i klinisk informationsmodellering dvs. in-vitro. Ved at spørge klinikere om deres behov for information fremfor at observere deres anvendelse af oplysninger åbner man for, hvad der hos Goguen et al.[102] er beskrevet som say-do-problemet: at hvad informanter siger, at de gør, afviger fra, hvad de faktisk gør.

- Det er desuden karakteristisk, at klinisk indhold, som det kommer til udtryk i de ovennævnte initiativer, fortrinsvis er rettet mod det, at sundhedsaktiviteter dokumenteres - dvs. sundhedsarbejderes ud-data. Dette i modsætning til denne afhandlings kontekstualiseringsblokke, som er skabt med udgangspunkt i lægers kontekstualisering - dvs. deres ind-data. 
De kontekstualiseringsblokke, som er beskrevet i denne afhandling, afviger således tydeligt fra tidligere forsøg på at beskrive blokke af kontekstuel klinisk information, der i et klinisk-logisk perspektiv har indbyrdes kognitiv sammenhæng.

\subsubsection{Konklusion}

Denne undersøgelse underbygger opfattelsen af, at kontekstualitet er situationel, og at kontekstuel klinisk information kan omfatte nogle meget komplekse relationer.

Undersøgelsen demonstrerer - i lighed med tidligere arbejder[60,61] - at læger optimerer deres kontekstualiseringsproces under hensyntagen til journalens informationsstruktur. Undersøgelsen påviser desuden, at denne optimering kan indebære ganske betydelig forekomst af split-attention, og det er sandsynliggjort, at man kan reducere forekomsten af split-attention ved at gøre det muligt for lægerne at tilegne sig kliniske oplysninger i en struktur, der i højere grad ligner lægernes klinisk-logiske informationsstruktur.

Der er i undersøgelsen anvendt en metode, som - med angivne justeringer - skønnes egnet til at kortlægge og generalisere klinisk-logisk informationsstruktur, og det er demonstreret, at der på tværs af læger og patienter kan identificeres blokke af kliniske oplysninger, som i et klinisk-logisk perspektiv har indbyrdes kognitiv sammenhæng. Det er sandsynliggjort, at sådanne blokke med fordel kan anvendes til at understøtte lægers kontekstualisering. 


\section{Diskussion}

\subsection{Hvad er kontekstuel klinisk information for læger? Og hvilken betydning har den for deres daglige kliniske arbejde?}

På baggrund af de definitioner, der er anvendt i denne afhandling, og den opfattelse af kontekstbegrebet, der er beskrevet i afsnit 7.3.4, side 34, kan kontekstuel klinisk information beskrives som beskrivelse af forhold og situationer, som i en given sammenhæng relateres til en enkelt person, og som bidrager til meningsfuld forståelse af dennes helbred, behandling eller pleje

Som det fremgår af beskrivelsen af situationel og organisatorisk/faglig kontekst i afsnit 7.3.5, side 35, indgår kontekst med vægt i sundhedsarbejde. Meget af denne kontekst vedrører generelle forhold; kun en mindre del relateres til den enkelte patient og falder dermed ind under den ovenstående opfattelse af kontekstuel klinisk information.

Det har været et væsentligt formål med studiet at afdække, hvad der i praksis udgør den kontekstuelle information. De tre studier gengivet i kapitel 8, side $41 \mathrm{ff}$, tegner tilsammen et billede af kontekstuel klinisk information med en produktionskontekstuel delmængde:

- kontekstuel klinisk information udgøres i stort omfang af oplysninger, som lægerne anvender til at danne sig et billede af patienten - vurderinger, observationer, ordinationer og beskrivelse af interventioner, som beskrevet i Tabel 1, side 24. Denne anvendelse er demonstreret i Frederiksberg-studiets illustrationer af klinisk-logisk informationsstruktur (se Figur 13, side 70, og Bilag 5).

- produktionskontekstuel klinisk information er den delmængde, som beskriver omstændighederne, hvorunder kliniske oplysninger er tilvejebragt, og som lægerne anvender for at vurdere oplysningernes relevans, vægt og troværdighed. Dette er illustrerer med eksemplerne 2, 4 og5, side 49f, og mere udførligt beskrevet i Bispebjerg-studiets afgrænsning af produktionskontekstuel klinisk information i afsnit 8.2, side 50 .

Man kan sige, at kontekstuel klinisk information tegner billedet af patienten, og den produktionskontekstuelle delmængde bestemmer, hvor klart og entydigt billedet kan blive. Uanset hvilket af de beskrevne kontekstperspektiver, man anvender, er kontekstuel klinisk information essentiel for lægers daglige arbejde.

Kontekstuel klinisk information optræder med grader af kompleksitet spændende fra det simple til det meget komplekse. Simple kontekstuelle relationer mellem kliniske oplysninger er illustreret på Figur 13, side 70, mens nogle mere komplekse relationer er illustreret i Eksempel 9 på side 70. 
Også for den produktionskontekstuelle delmængde er der observeret både simple kontekstuelle relationer, som illustreret i Tabel 10, side 58, og mere komplekse relationer, som illustreret i Figur 11, side 59 .

Udover kompleksiteten i, hvordan kontekstuelle oplysninger indbyrdes er relaterede, er nogle af oplysningerne i sig selv vanskeligt strukturerbare, jf. afsnit 8.2.3.2, side 57. De kontekstualiserede oplysninger er meget forskelligartede, ofte kvalitative, og ofte med dårligt afgrænsede udfaldsrum. Disse karakteristika er i dette studie strengt taget kun demonstreret for produktionskontekstuel klinisk information, men lader sig dog med eksempler fra den kliniske hverdag let generalisere til den samlede mængde af kontekstuel klinisk information.

\subsection{I hvilket omfang kan kontekstuel klinisk information operationaliseres med henblik på at understøtte lægers kliniske ræsonnement?}

Operationalisering af kontekstuel klinisk information omfatter to forskellige aspekter: et distributivt aspekt, som vedrører opsamling, udveksling og gengivelse af oplysninger, og et prospektivt aspekt, som vedrører forudsigelse af, hvilke oplysninger vil blive kontekstualiseret.

\subsubsection{Det distributive aspekt}

At opsamle, udveksle og gengive klinisk information - det distributive aspekt - udgør den grundlæggende ambition for årtiers sundhedsinformatiske udvikling. Operationalisering består - som anført i SemanticHealth-rapporten[4] - i at anvende standardiserede modeller og terminologier.

Helt generelt er dette en udfordring, hvilket illustreres af de mangfoldige tiltag for at standardisere klinisk information (HL7, openEHR, 13606, SnomedCT, ICD10, etc.), er påpeget i adskillige arbejder - fx. [5-8,37,38] - og udtrykkes tydeligt af Rector:

The clinical notes expressed in natural language will, for the foreseeable future, be richer in content and context than any formal representation of them. [5]

Som anført i starten af afhandlingen er ambitionen vokset over tid, indtil den i dag fremstår som visionen om ubegrænset pragmatisk interoperabilitet, hvor den basale forudsætning er, at kontekstuel klinisk information kan gengives og udveksles, så den kvantitativt og kvalitativt modsvarer lokal tilvejebringelse af kliniske oplysninger.

Store dele af klinisk information kan under anvendelse af de forskellige standarder opsamles, udveksles og gengives - herunder ikke mindst klinisk kerneinformation (diagnoser, resultater, beskrivelse af interventioner, etc.) og grundlæggende metainformation (patient-ID, forfatter, tid, sted, etc.). En diskussion af de forskellige standarders fortrin og deres anvendelighed i kombinationer lig- 
ger uden for denne afhandlings scope, men deres blotte antal og det meget betydelige arbejde, som ligger bag dem, udgør en tydelig indikation af, hvor vanskeligt det er at operationalisere det distributive aspekt af klinisk information.

Men der er også dele af kontekstuel klinisk information, som det ikke er lykkedes at standardisere. Denne afhandling afgrænser og beskriver den produktionskontekstuelle delmængde af klinisk information. Produktionskontekstuel klinisk information er af afgørende betydning for lægers arbejde, og det er - med henvisning til dens struktur, dens volumen og dens iboende mangel på suppleringsmulighed - belyst, hvorfor fyldestgørende gengivelse og udveksling er til umulighed grænsende vanskeligt. På denne baggrund konkluderes, at en realisering af visionen om ubegrænset pragmatisk interoperabilitet ikke er mulig.

At der ikke foreligger formelle standarder til at udtrykke informationen, er ikke en hindring for at opsamle, udveksle og gengive oplysninger, men kræver en lokal enighed mellem afsender og modtager om volumen, kvalitet og protokol. Selvsagt vil det være lettest at tilvejebringe en sådan enighed, hvis man sigter efter at udveksle specifikke oplysninger med specifikke formål og under hensyntagen til balancen mellem pris og udbytte ved at tilvejebringe oplysningerne[7].

\subsubsection{Det prospektive aspekt}

Det prospektive aspekt af operationalisering af kontekstuel klinisk information indebærer understøttelse af lægens kontekstualiseringsproces ved i situationen at stille relevante oplysninger til rådighed eller gøre lægen bekendt med de typer af oplysning, som er af forudsigelig interesse.

Anskuet i Dey's perspektiv er en aktivitets kontekst givet ved dens omstændigheder, som vidtgående kan forudsiges på grundlag af kendskab til systemet. Denne form for forudsigelse er kortfattet omtalt i næste afsnit om at forudsige produktionskontekstuel klinisk information. I det mere modne perspektiv omtalt i afsnit 7.3.4, side 34, må forudsigelse af lægers behov for kontekstuel information være baseret på probabilistiske overvejelser. Grundlaget for sådanne overvejelser er gjort til genstand for diskussion i de efterfølgende afsnit.

\section{Forudsigelse af behov for produktionskontekstuel klinisk information}

Denne afhandling omfatter en beskrivelse af produktionskontekstuel klinisk information, herunder at den benyttes til kildekritik - til at vurdere troværdigheden, relevansen og vægten af kliniske oplysninger. Hvor kontekstualisering af kliniske oplysninger generelt drejer sig om at skabe et indre billede af patienten (se evt. afsnit 8.3.2.3, side 69), tjener kontekstualiseringen af den produktionskontekstuelle delmængde til at øge billedets skarphed og kvalitet. 
Det er ikke i dette studie undersøgt, hvad der får læger til at kontekstualisere denne type information, og der er ikke spontant observeret nogen lovmæssighed heri. Formodentlig er lægens mistanke om manglende klinisk-logisk konsistens og/eller kausalitet en væsentlig udløsende faktor, men dette er spekulativt. På det foreliggende er der således ikke grundlag for at kunne forudsige lægers behov for produktionskontekstuel klinisk information med større præcision end, hvad der er betinget af metainformationsindholdet i den observerede sundheds-it.

\section{Aktivitetsbaseret forudsigelse af informationsbehov}

Én indfaldsvinkel til forudsigelse er at tage udgangspunkt i lægens aktivitet: Når lægen skal udføre givne handlinger, kan man sandsynliggøre, at hun vil kontekstualisere bestemte oplysninger. Handlingerne kan i den forbindelse anskues på flere niveauer - fra det overordnede (stuegang, indlæggelse, tilsyn) til det detaljerede (ordination af medicin, diagnosticering, vurdering af behandlingseffekt). Denne form for forudsigelse af lægers kontekstualiseringsbehov kommer til udtryk i sundhedsvæsenets mangfoldighed af vejledninger, jf. de nedenstående eksempler 10 og 11, som begge specificerer kontekstuel klinisk information i forhold til en sundhedsaktivitet:

Eksempel 10. Kontekstualisering i forbindelse med inklusion i pakkeforløb

I Sundhedsstyrelsens vejledning for hvordan praktiserende læger inkluderer patienter i brystkræft-pakken[103] anføres syv specifikke kriterier for at rejse begrundet mistanke om brystkræft, herunder palpatorisk suspekt tumor, nytilkommen papilretraktion, billeddiagnostisk suspekt forandring.

Anskuet i forhold til kontekstualisering er dette en specifikation af kliniske oplysninger, som skal kontekstualiseres i forhold til stille diagnose i en given situation.

Eksempe1 11. Kontekstualisering i forbindelse med anlæggelse af arteriekateter

I en instruks fra Hvidovre Hospital vedrørende anlæggelse af en arteriekanyle[104] anføres begrundelser, egnede kar, uegnede kar, komplikationer, forudgående undersøgelser, utensilieliste og procedurebeskrivelse - i alt 27 punkter.

Anskuet i forhold til kontekstualisering er dette en specifikation af kliniske oplysninger, som skal kontekstualiseres i forhold til en given aktivitet $i$ en given situation.

Man skal dog være opmærksom på, at sådanne angivelser af relevant information er begrænset af, $\mathrm{i}$ hvilket omfang forfatteren har forudset aktivitetens placering i det aktuelle workflow og de faktiske omstændigheder - en udfordring i en verden, hvor patienter meget ofte har flere konkurrerende sygdomme, er underkastet flere samtidige og interagerende behandlinger, og hvor enhver handling skal tilpasses til lokale forhold og omstændigheder. Fx. omtaler vejledningen i Eksempel 10 ikke, at der 
gælder andre kriterier for patienter, som tidligere er behandlet for brystkræft, og instruksen i Eksempel 11 beskriver ikke, at særlige forhold skal tages i betragtning, hvis patienten er i AKbehandling.

Forudsigelse af informationsbehov på baggrund af aktivitet indebærer - som eksemplificeret ovenfor - den svaghed, at det næppe er muligt prospektivt at forudsige alle relevante omstændigheder for en given sundhedsaktivitet - jf. den ovenstående diskussion om vanskelighederne ved retrospektiv tilvejebringelse og udveksling af fyldestgørende kontekstuel klinisk information. Det kan selvfølgelig $\mathrm{i}$ et vist omfang kompenseres ved at gøre aktivitetsbeskrivelsen meget detaljeret og omfangsrig $\mathrm{i}$ håbet om at dække "enhver tænkelig situation" - en mekanisme, som dog sjældent øger brugbarheden.

Denne problematik accentueres yderligere af, at aktivitetsbaseret forudsigelse af behovet for kontekstuel klinisk information helt overvejende er statisk: Der foreligger en beskrivelse af fremtidig aktivitet (procedurebeskrivelse, vejledning, instruks), men beskrivelsen ændrer sig ikke, hvis aktiviteten afviger fra det forventede. Denne statiske forudsigelse af informationsbehov skal sammenlignes med dynamisk forudsigelse, hvor afvigelser fra det forventede automatisk registreres og løbende danner grundlag for ændret forudsigelse. Sådan dynamisk forudsigelse af informationsbehov er kendt fx. fra almindelige GPS-navigatorer og fly (se evt. Wikipedias omtale af Bitching Betty, http://en.wikipedia.org/wiki/Bitching_Betty ), men har med den eksisterende teknologi ingen væsentlig udbredelse i sundhedsvæsenet.

\section{Informationsbaseret forudsigelse af informationsbehov}

En anden indfaldsvinkel er at tage udgangspunkt i lægens aktuelle kontekstualisering: Når lægen kontekstualiserer givne oplysninger, kan man sandsynliggøre, at hun supplerende vil kontekstualisere bestemte oplysninger.

I Frederiksberg-studiet - afsnit 8.3, side 63 - er det vist, at man med obser-view kan kortlægge lægernes klinisk-logiske informationsstruktur, og at man på dette grundlag kan identificere generelle strukturelle fragmenter - det, som i afsnit 8.3.2.5, side 72, er benævnt 'kontekstualiseringsblokke'. Det er - med udgangspunkt i en beskrivelse af, hvordan anvendelse af en kildeorienteret journal resulterede i split-attention - sandsynliggjort, at man kan nedsætte kognitiv load og understøtte klinisk ræsonnement ved at stille oplysninger til rådighed på en måde, som modsvarer lægernes klinisklogiske informationsstruktur, jf. Figur 18, side 78.

Det, at stille oplysninger til rådighed på grundlag af klinisk-logisk informationsstruktur og relateret til aktuel kontekstualisering, kan tænkes realiseret både top-down og bottom-up, som illustreret på figurerne 21 og 22: 


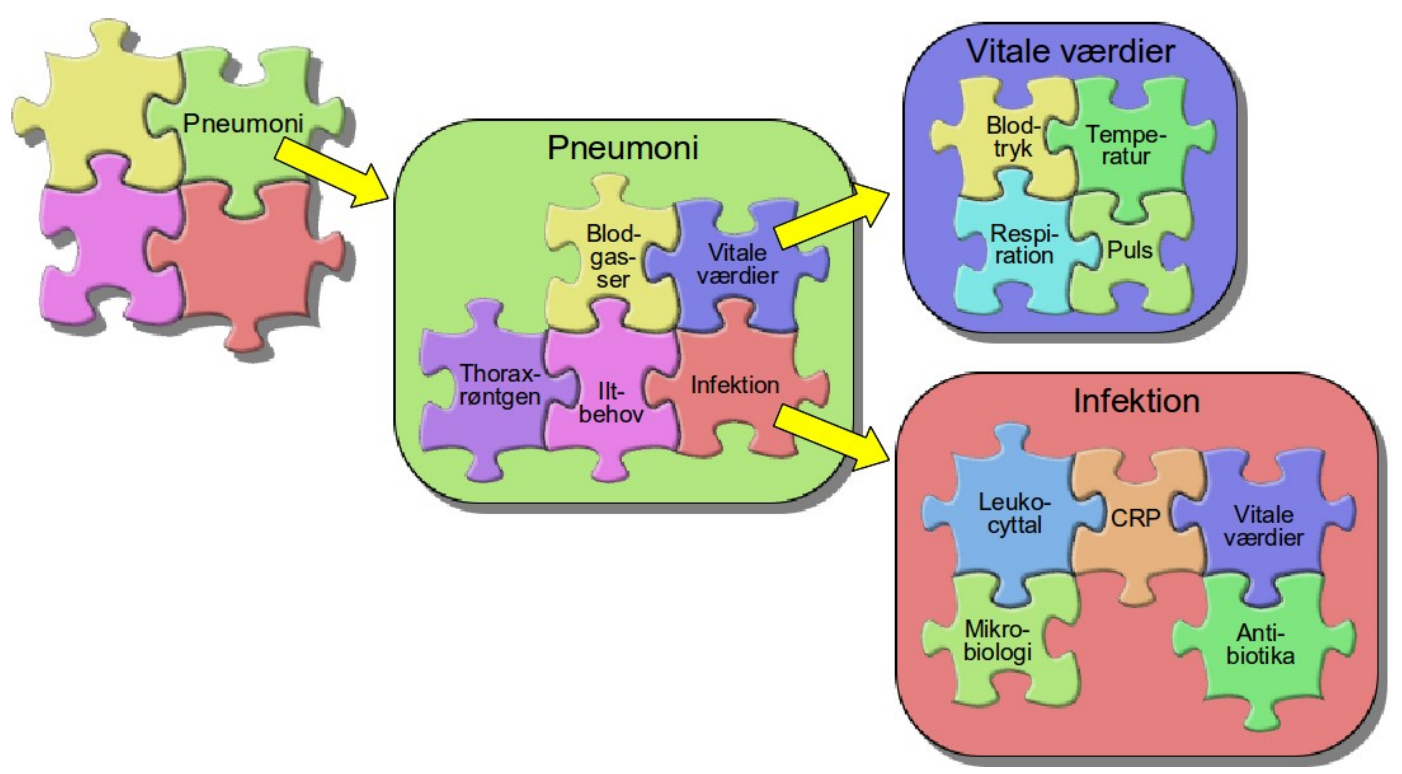

Figur 21. Eksempel på top-down forudsigelse af kontekstualisering: Hvis lægen kontekstualiserer "pneumoni" (uanset om det vedrører indlæggelsesårsag, komplikation, rutine-tjek, e.l.) vil hun derefter med stor sandsynlighed kontekstualisere vitale værdier (temperatur, respiration), thorax-røntgen og en række infektionsrelaterede oplysninger.
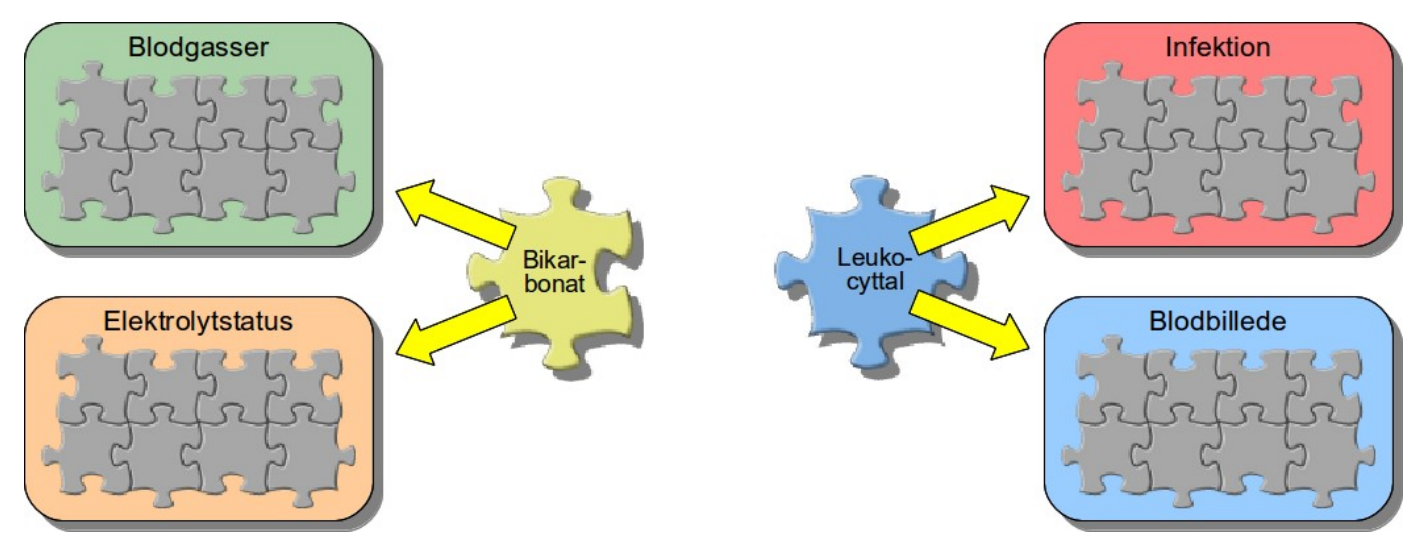

Figur 22. Eksempler på bottom-up forudsigelse af kontekstualisering: Hvis lægen kontekstualiserer "bikarbonat" vil hun med stor sandsynlighed også kontekstualisere blodgasser og/eller elektrolytstatus. Hvis lægen kontekstualiserer "leukocyttal", vil hun med stor sandsynlighed også kontekstualisere yderligere infektionsrelaterede oplysninger eller blodbillede.

Den informationsbaserede forudsigelse af kontekstualisering har det helt centrale fortrin, at man ved at registrere lægens interaktion med informationssystemet (museklik og tastetryk) kan tilvejebringe løbende og tidstro information om, hvilke oplysninger lægen kontekstualiserer. Dette skal ses i modsætning til den aktivitetsbaserede tilgang, hvor informationen afspejler den intenderede aktivitet, dvs. aktivitetens startkonditioner. Den løbende og tidstro information om lægens kontekstualisering indebærer, at informationssystemet løbende kan tilpasse sig ændringer i situationen, og således har mulighed for at foretage dynamisk forudsigelse af informationsbehov.

Som anført i afsnit 8.2.3.6, side 62, kan klinisk information blive kontekstualiseret på en måde, hvor kontekstualisering af én oplysning er bestemmende for hvilke oplysninger, der efterfølgende kon- 
tekstualiseres. Selv med minutiøst specificerede handlinger og de bedste algoritmer må man forvente, at læger vil kontekstualisere oplysninger, som ikke var forudset. Et system baseret på aktuel kontekstualisering vil have en chance for at "følge med" mens et system, som alene er baseret på startkonditioner, hurtigt vil kunne "tabe tråden".

At kunne foretage detaljeret registrering af lægers kontekstualisering åbner desuden op for nogle spændende muligheder i form af, at bygge lærende informationssystemer, hvor forudsigelse automatisk kan baseres på hvad den enkelte læge eller en gruppe af læger tidligere har kontekstualiseret. Princippet er velkendt hos Google og Amazon: "Andre, der købte denne bog, bestilte også...".

Informationsbaseret forudsigelse af lægers informationsbehov synes således at have et betydeligt potentiale - endda indenfor rammerne af eksisterende teknologi. 



\section{Opsamling og perspektivering}

Formålet med dette studie var - ud fra et læge-perspektiv - at undersøge, hvad der udgør kontekstuel klinisk information, hvilken betydning den har, og hvordan den kan operationaliseres.

Terminologisk arbejde har en fremtrædende plads i denne afhandling. En række termer - fx. dobbeltregistrering, datagenbrug, journal, kontekstualitet og kontekst - er almindeligt anvendt indenfor sundhedsinformatik og synes at indebære en velkendt mening. Alligevel viser det sig, at de underliggende begreber er uskarpe eller ligefrem flertydige. Væsentlige dele af dette studie har derfor været centreret om at tilvejebringe en konsistent opfattelse af disse begreber - ikke blot baseret på definitioner, men på supplerende fortolkning. Specielt har kontekst-begrebet krævet omfattende fortolkning, og væsentlige aspekter af studiet er belyst ud fra to forskellige kontekst-paradigmer. Den resulterende fortolkning af kontekst og kontekstualisering er gengivet i afsnit 7.3.4, side 34, og på den baggrund kan kontekstuel klinisk information beskrives som:

beskrivelse af forhold og situationer, som i en given sammenhæng relateres til en enkelt person, og som bidrager til meningsfuld forståelse af dennes helbred, behandling eller pleje

Studiet har identificeret en delmængde af kontekstuel klinisk information, der beskriver de omstændigheder, hvorunder kliniske oplysninger er produceret - produktionskontekstuel klinisk information - og det er er påvist, at lægerne bruger denne type information til at vurdere kliniske oplysningers relevans, vægt og troværdighed. Studiet har demonstreret, at produktionskontekstuel klinisk information er essentiel for lægers kliniske arbejde og har betydning for omfanget af dobbeltregistrering og dobbeltundersøgelse. Der er endvidere beskrevet en række aspekter ved produktionskontekstuel klinisk information, som effektivt begrænser dens anvendelse - både generelt $\mathrm{i}$ forhold til operationalisering og mere specifikt i forhold til at kunne etablere pragmatisk interoperabilitet.

Afhandlingen beskriver en metode til at registrere og visualisere den klinisk-logiske struktur, som opbygges under en læges kontekstualisering. Det er sandsynliggjort, at der på grundlag af sådanne registreringer på tværs af læger og patienter kan generaliseres fragmenter af informationsstruktur 'kontekstualiseringsblokke' - som kan benyttes til operationalisering af kontekstuel klinisk information.

Mulighederne for at operationalisere kontekstuel klinisk information er desuden blevet analyseret, idet der i analysen er sondret mellem det distributive aspekt (operationalisering gennem transport af information) og det prospektive aspekt (operationalisering gennem forudsigelse af kontekstualisering). Det er påpeget, at operationalisering af kontekstuel klinisk information hidtil væsentligst er 
sket indenfor det distributive aspekt gennem anvendelse af standardiserede modeller og terminologier, og indenfor det prospektive aspekt gennem aktivitetsbaseret forudsigelse af kontekstualisering. Med udgangspunkt i dette studies resultater anføres det, at der indenfor operationalisering af kontekstuel information er et betydeligt potentiale i informationsbaseret forudsigelse af kontekstualisering. Studiet beskriver begreber og metoder, som er centrale for at realisere dette potentiale.

\subsection{Konklusioner og fremtidige studier}

På baggrund af dette studie konkluderes:

- Produktionskontekstuel klinisk information - beskrivelse af omstændigheder, hvorunder kliniske oplysninger er produceret - er af afgørende betydning for lægers daglige kliniske arbejde. Denne type information er voluminøs og meget vanskelig at udtrykke struktureret.

- På grund af produktionskontekstuel klinisk informations særlige karakteristika forekommer det udsigtsløst at stræbe efter en udtømmende standardisering af denne informationstype. En eventuel standardisering bør sigte på specifikke, afgrænsede formål.

- Visionen om ubegrænset pragmatisk interoperabilitet, som den er beskrevet i SemanticHealthrapporten[4], kan - alene på grund af kravet om fyldestgørende produktionskontekstuel klinisk information - ikke realiseres.

- Der eksisterer kliniske informationssystemer, som kun mangelfuldt understøtter lægers klinisk-logiske informationsstruktur. Dette øger lægernes kognitive belastning, og påvirker herigennem sikkerhed og kvalitet negativt.

- Det er muligt at kortlægge og visualisere lægers klinisk-logiske informationsstruktur. Det er med eksempler vist, at dele af denne informationsstruktur kan generaliseres. Dette ses som et skridt på vejen mod udvikling af sundheds-it, der i højere grad understøtter lægers kontekstualisering af klinisk information.

- Med baggrund i diskussionen om informationsbaseret forudsigelse af lægers kontekstualisering er det vurderingen, at man med eksisterende teknologi kan realisere automatisk, lærende beslutningsstøtte i kliniske informationssystemer.

På denne baggrund foreslås:

- En generel holdningsændring til udvikling af sundheds-it med et mindre fokus på standardisering af produktionskontekstuel klinisk information og et større fokus på at understøtte sundhedsarbejdernes kontekstualisering.

- Yderligere in-vivo afprøvning og udvikling af den beskrevne metode til at afdække, visualisere og generalisere lægers klinisk-logiske informationsstruktur.

- In-vitro eksperimenter med informationssystemer baseret på klinisk-logisk informationsstruktur - fx. gennem simulationer i usability-laboratorie. 
- Udvikling af kliniske informationssystemer, som bedre er i stand til at understøtte lægernes klinisk-logiske informationsstruktur.

- Udvikling af klinisk beslutningsstøtte baseret på konceptet om informationsbaseret forudsigelse af informationsbehov. 



\section{Termer og forkortelser}

13606-standarden

EN/ISO-13606:2008. Health informatics - Electronic health record communication[18]

CEN (Comité Européen de Normalisation)

europæisk standardiseringsorganisation

URL: http://www.cen.eu/

\section{CONTSYS}

EN-13940:2007. Health informatics - System of concepts to support continuity of care

- Part 1: Basic concepts[25]

datagenbrug

tilvejebringelse af oplysninger gennem automatisk behandling eller kopiering af eksisterende information

Defineret $i$ afsnit 8.1 , side 42.

digital journal

den del af en journal som udgøres af digitale elementer

Note: Herunder digitale adgange til fx. laboratoriesystem, kontinuationer, medicinliste.

dobbeltregistrering

manuel registrering af oplysninger, som allerede eksisterer indenfor relevante kilder

Defineret i afsnit 8.1, side 42 .

dobbeltundersøgelse

fornyet frembringelse af oplysninger, som allerede eksisterer indenfor relevante kilder

Defineret i afsnit 8.1, side 42 .

HiMSS (Healthcare Information and Management Systems Society)

en non-profit organisation som arbejder for at udvikle og udbrede sundheds-it

URL: http://www.himss.org/

HISA-standarden

EN/ISO-12967:2009 Health informatics - Service architecture

\section{HL7 (Health Level Seven)}

en non-profit organisation som udvikler standarder for udveksling af sundhedsdata

URL: http://www.hl7.org/ 


\section{ICD (International Classification of Diseases)}

WHO's internationale klassifikation af sygdomme

URL: http://www.who.int/classifications/icd/

interoperabilitet

(se afsnit 7.2, side 26)

ISO (International Organization for Standardization)

international standardiseringsorganisation

URL: http://www.iso.org/

journal

den samlede mængde af informationsbærende elementer som lokalt stiller registrerede kliniske oplysninger til rådighed

Note: Termen 'journal' har i daglig tale to betydninger - journalen som beholder og journalen som indhold. I denne afhandling benyttes termen journal udelukkende $\mathrm{i}$ førstnævnte betydning.

Note: Registrerede kliniske oplysninger kan være til rådighed i papirbaseret eller digital form eller en kombination heraf - se hhv. 'papirbaseret journal' og 'digital journal'.

\section{klinisk information}

Synonym: 'klinisk oplysning' - se dette.

\section{klinisk oplysning}

oplysning som vedrører en enkelt person og som er af relevans for dennes helbred, behandling eller pleje

Synonym: klinisk information

Kilde: ISO 13606-1:2008. Health informatics - Electronic health record communication - Part 1: Reference model[18]

\section{kontekst}

forhold og situationer som bidrager til meningsfuld forståelse af et givet emne

Note: Inspireret af ISO/TR 17119:2005. Health informatics - Health informatics profiling framework[105]

Note: 'Forhold og situationer' omfatter i denne forbindelse også fraværende og hypotetiske forhold og situationer.

kontekstualisere

at gøre noget til kontekst

kontekstuel information

information som beskriver kontekst 
kontekstuel klinisk information

klinisk information som beskriver kontekst

$\underline{\text { metadata }}$

data der definerer og beskriver andre data

Note: Oversat fra ISO/IEC 11179-1:2004[90]: 'metadata'

NHS (National Health Service)

den engelske pendant til Sundhedsstyrelsen

URL: http://www.nhs.uk

openEHR

en non-profit organisation som udvikler standarder for lagring og udveksling af sundhedsdata

URL: http://www.openehr.org/

papirbaseret journal

den del af en journal som udgøres af papirbaserede elementer

Note: Herunder ark med kontinuationer, lab-svar, røntgenbeskrivelser.

pragmatisk interoperabilitet

(se afsnit 7.2.1, side 26)

produktionskontekstuel klinisk information

beskrivelse af omstændighederne, hvorunder kliniske oplysninger er blevet produceret semantisk interoperabilitet

(se afsnit 7.2.1, side 26)

$\underline{\text { SNOMED CT (SNOMED Clinical Terms) }}$

IHTSDO's omfattende, kliniske terminologi

URL: http://www.ihtsdo.org/snomed-ct/

sundheds-it

informationsteknologi som vedrører design, udvikling, implementering, brug og vedligeholdelse af informationssystemer til sundhedssektoren

Synonymer: health information technology, HIT

$\underline{\text { sundhedsaktivitet }}$

aktivitet, som udføres for en patient med henblik på direkte eller indirekte at forbedre eller bevare dennes helbred

Note: Oversat fra CONTSYS[25]: 'health care activity' 
sundhedsarbejder

en person som er autoriseret til professionelt at udføre behandling, pleje, undersøgelse eller forebyggelse

Note: Fx. læge, sygeplejerske, fysioterapeut, radiograf.

Note: Modsvarer 'healthcare professional' i CONTSYS[25].

$\underline{\text { sundhedsinformatik }}$

viden, færdigheder og værktøjer som gør det muligt at samle, håndtere, bruge og dele information med henblik på at levere sundhedsydelser og at fremme sundhed.

Note: Oversat fra [106]: 'health informatics'

\section{UMLS (Unified Medical Language System)}

National Library of Medicine's system af terminologi og semantisk netværk til at udtrykke og fremfinde sundhedsrelaterede begreber

URL: http://www.nlm.nih.gov/research/umls/ 


\section{Litteratur}

1. HiMSS Analytics. EMR Adoption Model for Europe. 2012; URL:

( http://www.himssanalytics.eu/sites/default/files/HAE_EMRAM_Overview_Stages_2012.pdf). Accessed 01/03/2014.

2. Burns F. Information for health: an information strategy for the modern NHS 1998-2005. : NHS Executive; 1998.

3. Lippert S, Kverneland A. The Danish National Health Informatics Strategy. Stud Health Technol Inform 2003;95:845-850.

4. Stroetmann V, Kalra D, et al. Semantic Interoperability for Better Health and Safer Healthcare. Luxembourg: European Commission; 2009.

5. Rector A. Clinical terminology: why is it so hard? Methods Inf Med. 1999 Dec;38(4-5):239-252.

6. Ingenerf J. Telemedicine and terminology: different needs of context information. IEEE Trans.Inf.Technol.Biomed. 1999 Jun;3(2):92-100.

7. Berg M, Goorman E. The contextual nature of medical information. Int.J.Med.Inf. 1999;56(1-3):51-60.

8. Berg M, Toussaint PJ. The mantra of modeling and the forgotten powers of paper: a sociotechnical view on the development of process-oriented ICT in health care. Int.J.Med.Inf. 2003;69(2-3):223-234.

9. Greenhalgh T. Narrative based medicine in an evidence based world. BMJ 1999;318(7179):323-325.

10. Galster G. How to Distinguish Double Documentation from Documentation of Distinct Data. In: Fensli R, Dale JG, editors. SHI2011 Proceedings : 9th Scandinavian Conference on Health Informatics, 30 August 2011. Oslo, Norway: TAPIR Akademisk Forlag; 2011. p. 16-20.

11. Galster G. Why is clinical information not reused? Stud Health Technol Inform 2012;180:624-628.

12. Galster G. Production-contextual clinical information. Lecture Notes in Computer Science 2013;8175:248-258.

13. Galster G. Contextualisation of clinical information from fragmented health records. Stud Health Technol Inform 2013;194:41-47.

14. Bemmel JH, Musen MA, et al. Handbook of medical informatics. : Bohn Stafleu Van Loghum Houten; 1997.

15. Reddy MC, Dourish P, et al. Coordinating heterogeneous work: Information and representation in medical care. ECSCW 2001: Springer; 2002. p. 239-258.

16. Bardram JE, Bossen C. A web of coordinative artifacts: collaborative work at a hospital ward. Proceedings of the 2005 international ACM SIGGROUP conference on Supporting group work: ACM; 2005. p. 168-176.

17. Bansler JP, Havn EC, et al. A study of the fragmentation of the medical record. In: Bjørn P, Kensing F, et al, editors. Infrastructure for Healthcare: Global Heathcare : Proceedings of the 3rd International Workshop 2011 Copenhagen, Denmark: IT-university; 2012.

18. ISO 13606-1:2008. Health informatics - Electronic health record communication - Part 1: Reference model. Geneva, Switzerland: ISO; 2008. 
19. Shortliffe EH. The evolution of electronic medical records. Acad Med 1999;74:414-419.

20. Rindum JL, Galster G, et al. Projekt SFI2, Nødvendig infrastruktur for rationel udnyttelse af SFI. 2008;

URL:( http://www.regionh.dk/NR/rdonlyres/50894ED3-A266-4FD0-8756-

BACDF9DEC3F1/0/Afslutningsrapport_SFI_vaerktoejer.pdf). Accessed 01/03/2014.

21. Region Hovedstaden, Rindum JL. Slutrapport Projekt Sundhedsfagligt Indhold SFI - Hovedstaden.

2007; URL:( http://www.regionh.dk/NR/rdonlyres/A0B5F2E7-33A4-4963-8B33-

517AD3D5E321/0/Slutrapport_SFIH_2007.pdf). Accessed 01/03/2014.

22. Region Hovedstaden. OPUS-notatskabelon. 2010; URL:

( http://www.regionh.dk/menu/sundhedOghospitaler/SFI/OPUS-notatskabelon.htm ). Accessed $01 / 03 / 2014$.

23. Beale T, Heard S. openEHR Architecture Overview. 2008; URL:

( http://www.openehr.org/releases/1.0.2/architecture/overview.pdf ). Accessed 01/03/2014.

24. Beale T, Heard S. An ontology-based model of clinical information. Stud Health Technol Inform 2007;129:760-764.

25. CEN. EN 13940-1: Health Informatics-System of Concepts to Support Continuity of Care-Part 1: Basic Concepts. Brussels: European Committee For Standardization; 2007.

26. NHS continuity of care concept model. 2011; URL:( http://www.datadictionary.nhs.uk/contsys/ ). Accessed 01/03/2014.

27. ISO 18308:2011 Health informatics - Requirements for an electronic health record architecture. Geneva, Switzerland: ISO; 2011.

28. Asuncion C, van Sinderen M. Pragmatic Interoperability: A Systematic Review of Published Definitions. Enterprise Architecture, Integration and Interoperability 2010;326:164-175.

29. Hammond WE, Bailey C, et al. Connecting information to improve health. Health Aff. 2010;29(2):284.

30. American Health Information Management Association. Implementation of SNOMED-CT Needed to Facilitate Interoperable Exchange of Health Information. Journal of AHIMA / American Health Information Management Association 2005;76(9 (October)):30-32.

31. Danske Regioner. EPJ-arkitektur II : - Afrapportering fra regionernes arbejdsgruppe om IT-arkitektur. Copenhagen, Denmark: Danske Regioner; 2007.

32. Indenrigs- og Sundhedsministeriet, Sundhedsstyrelsen. Analyse af kvalitetsoplysninger i Danmark - Juni 2010. Copenhagen, Denmark: Indenrigs- og Sundhedsministeriet; 2010.

33. Ingenerf J, Reiner J, et al. Standardized terminological services enabling semantic interoperability between distributed and heterogeneous systems. Int.J.Med.Inform. 2001 Dec;64(2-3):223-240.

34. ISO 1087-1:2000 Terminology work - Vocabulary - Part 1: Theory and application. Geneva, Switzerland: ISO; 2000.

35. Dey AK. Understanding and using context. Personal and ubiquitous computing 2001;5(1):4-7.

36. Dey AK, Abowd GD. Towards a better understanding of context and context-awareness. CHI 2000 workshop on the what, who, where, when, and how of context-awareness. : Citeseer; 2000. p. 1-6.

37. Bricon-Souf N, Newman CR. Context awareness in health care: a review. Int.J.Med.Inform. 2007 Jan;76(1):2-12. 
38. Winograd T. Architectures for context. Hum.-Comput.Interact. 2001;16(2):401-419.

39. Wiebe J, Hirst G, et al. Language use in context. Commun ACM 1996;39(1):102-111.

40. Degoulet P, Sauquet D, et al. Rationale and design considerations for a semantic mediator in health information systems. Methods Inf.Med. 1998 Nov;37(4-5):518-526.

41. Berg M. Implementing information systems in health care organizations: myths and challenges. Int.J.Med.Inf. 2001;64(2):143-156.

42. Zimmermann A, Lorenz A, et al. An operational definition of context. In: Kokinov B., editor. Proceedings of the 6th international and interdisciplinary conference on Modeling and using context: Springer-Verlag; 2007. p. 558-571.

43. Dourish P. What we talk about when we talk about context. Pers Ubiquit Comput 2004;8(1):19-30.

44. Schramm W. How communication works. In: Schramm W, editor. The process and effects of mass communication. Urbana: University of Illinois Press; 1954. p. 3-26.

45. Beuscart-Zéphir M, Pelayo S, et al. Cognitive analysis of physicians and nurses cooperation in the medication ordering and administration process. Int.J.Med.Inf. 2007;76:S65-S77.

46. Bansler JP, Havn EC, et al. Physicians' progress notes - The integrative core of the medical record. In: Bertelsen OW, Grasso MA, et al, editors. ECSCW 2013: 13th European Conference on ComputerSupported Cooperative Work, 21-25 September; 2013.

47. Schmidt K, Bannon L. Taking CSCW seriously. Computer Supported Cooperative Work (CSCW) 1992;1(1-2):7-40.

48. Garfinkel H, Bittner E. "Good" organizational reasons for "bad" clinic records. In: Garfinkel H, editor. Studies of Ethnomethodology. Englewood-Cliffs, New Jersey: Prentice-Hall; 1967. p. 186-207.

49. Nelson DAF. A defined minimum data set. Will it work for direct patient care? Comput.Nurs. 1997 Mar-Apr;15(2 Suppl):S43-7.

50. Brattheim B, Faxvaag A, et al. When Information Sharing is not Enough. Stud Health Technol Inform 2011;169:359-363.

51. Kassirer JP, Gorry GA. Clinical problem solving: a behavioral analysis. Ann Intern Med 1978;89(2):245-255.

52. Patel VL, Groen GJ. The general and specific nature of medical expertise: A critical look. Toward a general theory of expertise: Prospects and limits 1991:93-125.

53. Wulff HR, Gøtzsche PC. Rationel klinik. 4th ed. København: Munksgaard; 2000.

54. Backlund L, Skånér Y, et al. Doctors' decision processes in a drug-prescription task: The validity of rating scales and think-aloud reports. Organ.Behav.Hum.Decis.Process. 2003;91(1):108-117.

55. Arocha JF, Wang D, et al. Identifying reasoning strategies in medical decision making: a methodological guide. J.Biomed.Inform. 2005;38(2):154-171.

56. Joseph G, Patel VL. Domain knowledge and hypothesis generation in diagnostic reasoning. Medical Decision Making 1990;10(1):31-44.

57. Nygren E, Lind M, et al. The art of the obvious. Proceedings of the SIGCHI conference on Human factors in computing systems: ACM; 1992. p. 235-239. 
58. Elting LS, Martin CG, et al. Influence of data display formats on physician investigators' decisions to stop clinical trials: prospective trial with repeated measures. BMJ 1999;318(7197):1527-1531.

59. Beuscart-Zéphir M, Anceaux F, et al. Integrating users' activity modeling in the design and assessment of hospital electronic patient records: the example of anesthesia. Int.J.Med.Inf. 2001;64(2):157-171.

60. Patel VL, Kushniruk AW, et al. Impact of a computer-based patient record system on data collection, knowledge organization, and reasoning. Journal of the American Medical Informatics Association 2000;7(6):569-585.

61. Kannampallil TG, Franklin A, et al. Understanding the nature of information seeking behavior in critical care: Implications for the design of health information technology. Artif.Intell.Med. 2012 Nov 26.

62. Jensdottir AB, Jonsson P, et al. Comparison of nurses' and physicians' documentation of functional abilities of older patients in acute care, patient records compared with standardized assessment. Scand.J.Caring Sci. 2008 Sep;22(3):341-347.

63. Danske Regioner. Pejlemærker for sundheds-IT. Copenhagen, Denmark: Danske Regioner; 2010.

64. Winter A, Haux R, et al. Quality of Health Information Systems. Health Information Systems Architectures and Strategies. London: Springer; 2011. p. 201-236.

65. Ammenwerth E, Buchauer A, et al. Mobile information and communication tools in the hospital. Int.J.Med.Inform. 2000 Jan;57(1):21-40.

66. Indenrigs- og Sundhedsministeriet. National IT-strategi for sundhedsvæsenet 2003-2007. Copenhagen, Denmark: Indenrigs-og Sundhedsministeriet; 2003.

67. Gräsner JT, Meybohm P, et al. A national resuscitation registry of out-of-hospital cardiac arrest in Germany, a pilot study. Resuscitation 2009;80(2):199-203.

68. Regeringen, Danske Regioner. Aftale om regionernes økonomi for 2011. 2010; URL: ( http://www.regioner.dk/Aktuelt/Nyheder/2010/Juni/ /media/E73931B6E7054412B39FE343EB3DA99 E.ashx ). Accessed 01/04/2014.

69. Wille-Jørgensen PA, Meisner S. Datavaliditeten i en operationsregistrering. En kvalitetsanalyse. Ugeskr.Laeger 1997 Dec 1;159(49):7328-7330.

70. Lundgreen A, Hesselbo B, et al. Tværfaglighed og dobbeltdokumentation i EPJ. 2006; URL: ( http://projekter.aau.dk/projekter/files/6146655/Rapport\%20Tv\%C3\%A6rfaglighed\%20og\%20do.pdf ). Accessed 09/23/2013.

71. Mabeck H. Dobbeltregistrering af medicinordinationer kan vaere en god kvalitetskontrol. Ugeskr.Laeger $2011 \mathrm{Feb} 21 ; 173(8): 562-564$.

72. Rigsrevisionen. Beretning til Statsrevisorerne om elektroniske patientjournaler på sygehusene. Copenhagen, Denmark: Rigsrevisionen; 2011.

73. Nordgaard-Andersen I. Repeated ECG recording, benefits]. Ugeskr.Laeger 1991 Apr 8;153(15):10511052.

74. $\mathrm{Xu} \mathrm{J}$, Ishikawa $\mathrm{H}$, et al. Translation histogram based hierarchical algorithm for 3-d optic nerve head modeling. Conf.Proc.IEEE Eng.Med.Biol.Soc. 2007;2007:6752-6755.

75. Abeler VM, Kjørstad KE, et al. Carcinoma of the endometrium in Norway: a histopathological and prognostic survey of a total population. Int J Gynecol Cancer 1992;2(1):9-22. 
76. Makombe SD, Jahn A, et al. A national survey of teachers on antiretroviral therapy in Malawi: access, retention in therapy and survival. PLoS One 2007 Jul 18;2(7):e620.

77. Sundhedsministeriet. National strategi for IT i sygehusvæsenet 2000-2002. Copenhagen, Denmark: Sundhedsministeriet; 1999.

78. Doyal L. Informed consent in medical research: Journals should not publish research to which patients have not given fully informed consent-with three exceptions. BMJ 1997;314(7087):1107.

79. Marco AP. Informed consent for surgical anesthesia care: has the time come for separate consent? Anesth Analg 2010;110(2):280-282.

80. Kush R, Alschuler L, et al. Implementing Single Source: the STARBRITE proof-of-concept study. J Am Med Inf Assoc 2007;14(5):662-673.

81. Cimino JJ. Collect once, use many. Enabling the reuse of clinical data through controlled terminologies. J AHIMA 2007 Feb;78(2):24-9; quiz 31-2.

82. Hazle NR. Perceptions of role conflict between obstetric nurses and nurse-midwives. J.Nurse. 1985;30(3):166-173.

83. West MA, Poulton BC. A failure of function: teamwork in primary health care. J Interprof Care 1997;11(2):205-216.

84. Duffy W, Duffy MC. Power perceived is power achieved - power struggles in perioperative nursing. AORN J 1998;68(1):89-92.

85. Mabeck H. Implementation of an electronic medication system and disregarded power of the record. Stud Health Technol Inform 2008;136:443-448.

86. Hubner-Bloder G, Duftschmid G, et al. Clinical situations and information needs of physicians during treatment of diabetes mellitus patients: a triangulation study. Stud Health Technol Inform 2011;169:369373.

87. Kitzinger J. Qualitative research: introducing focus groups. BMJ 1995;311(7000):299-302.

88. Burnett $\mathrm{K}, \mathrm{Ng} \mathrm{KB}$, et al. A comparison of the two traditions of metadata development. Journal of the American Society for Information Science 1999;50(13):1209-1217.

89. National Information Standards Organization. Understanding Metadata. Bethesda, USA: NISO Press; 2004.

90. ISO/IEC 11179-1:2004 Information technology - Metadata registries (MDR) - Framework. 2nd ed. Geneva, Switzerland: ISO/IEC; 2004.

91. Kushniruk AW, Patel VL. Cognitive and usability engineering methods for the evaluation of clinical information systems. J.Biomed.Inform. 2004;37(1):56-76.

92. Kragelund L. Student nurses' learning processes in interaction with psychiatric patients: A qualitative investigation. Nurse Education in Practice 2011;11(4):260-267.

93. Nøhr C, Sørensen M, et al. Method for testing a CPOE system in the medication process in a cardiology ward. Stud Health Technol Inform 2010;160(Pt 1):183.

94. Hertzum M, Hansen KD, et al. Scrutinising usability evaluation: does thinking aloud affect behaviour and mental workload? Behav Inform Technol 2009;28(2):165-181. 
95. Patel VL, Groen GJ, et al. Medical expertise as a function of task difficulty. Mem.Cognit. 1990;18(4):394-406.

96. Chandler P, Sweller J. The split-attention effect as a factor in the design of instruction. Br.J.Educ.Psychol. 1992;62(2):233-246.

97. Ginns P. Integrating information: A meta-analysis of the spatial contiguity and temporal contiguity effects. Learning and Instruction 2006;16(6):511-525.

98. Laxmisan A, Hakimzada F, et al. The multitasking clinician: decision-making and cognitive demand during and after team handoffs in emergency care. Int.J.Med.Inf. 2007;76(11):801-811.

99. openEHR. Working with templates. URL:

( http://www.openehr.org/downloads/ADLworkbench/working with templates ). Accessed 01/03/2014.

100. Brull R. What is Consolidated CDA? 2012; URL:

( http://www.hl7standards.com/blog/2012/03/22/consolidated-cda/ ). Accessed 01/03/2014.

101. NHS. National Clinical Content Repository (NCCR). 2012; URL:

( http://www.connectingforhealth.nhs.uk/systemsandservices/clinrecords/nccr ). Accessed 12/13/2013.

102. Goguen JA, Linde C. Techniques for requirements elicitation. Requirements Engineering, 1993., Proceedings of IEEE International Symposium on: IEEE; 1993. p. 152-164.

103. Sundhedsstyrelsen. Brystkræft, oversigt over indgang til pakkeforløb - til brug i almen praksis. 2012; URL:( www.sst.dk/ /media/Planlaegning\%20og\%20kvalitet/Kraeftbehandling/Indgang\%20oversigt \%20pakker\%20161012/Brystkr\%C3\%A6ft_Oversigt\%20over\%20indgang\%20til\%20pakkeforl \%C3\%B8b_FINAL.ashx ). Accessed 10/23/2013.

104. Børch K. Arteriekanyleanlæggelse. 2008; URL: ( http://www.hosp.dk/hvh/kvalibog.nsf/bilagsView/D81B93167AFE6853C12574F1004B6E53/\$File/Art eriekanyleanl\%C3\%A6ggelse.doc ). Accessed 01/03/2014.

105. ISO TR 17119:2005 Health informatics - Health informatics profiling framework. Geneva, Switzerland: ISO; 2005.

106. UK Department of Health. Making Information Count: A Human Resources Strategy for Health Informatics Professionals. : Department of Health; 2002. 


\section{Bilagsliste}

Bilag 1

Publiceret, peer-reviewed paper: "How to Distinguish Double Documentation from Documentation of Distinct Data"

\section{Bilag 2}

Publiceret, peer-reviewed paper: "Why Is Clinical Information Not Reused?"

Bilag 3

Publiceret, peer-reviewed paper: "Production-Contextual Clinical Information"

$\underline{\text { Bilag } 4}$

Publiceret, peer-reviewed paper: "Contextualisation of Clinical Information from Fragmented Health Records"

Bilag 5

Eksempler på klinisk-logiske informationsstrukturer

\section{Bilag 6}

Eksempler på identificerede kontekstualiseringsblokke 



\title{
How to Distinguish Double Documentation from Documentation of Distinct Data
}

\author{
Gert Galster \\ Department of Health Science and Technology, Aalborg University, Aalborg, Denmark \\ Galster G. How to Distinguish Double Documentation from Documentation of Distinct \\ Data. In: Fensli R, Dale JG, editors. SHI2011 Proceedings : 9th Scandinavian \\ Conference on Health Informatics, 30 August 2011. Oslo, Norway: TAPIR Akademisk \\ Forlag; 2011. p. 16-20.
}


A part of this thesis has been removed from this publication due to copyright. 


\section{Bilag 2}

\section{Why Is Clinical Information Not Reused?}

Gert Galster

Medical Informatics Group, Department of Health Science and Technology, Aalborg University, Aalborg, Denmark

Galster G. Why is clinical information not reused? Stud.Health Technol.Inform. 2012;180:624-628.

DOI: $10.3233 / 978-1-61499-101-4-624$ 
A part of this thesis has been removed from this publication due to copyright. 


\title{
Production-Contextual Clinical Information
}

\author{
Gert Galster \\ Medical Informatics Group, Department of Health Science and Technology, Aalborg University, \\ Aalborg, Denmark
}

Galster G. Production-contextual clinical information. Lecture Notes in Computer Science 2013;8175:248-258

DOI: $10.1007 / 978-3-642-40972-1 \_19$ 
A part of this thesis has been removed from this publication due to copyright. 


\title{
Contextualisation of Clinical Information from Fragmented Health Records
}

\author{
Gert Galster \\ Medical Informatics Group, Department of Health Science and Technology, Aalborg University, \\ Aalborg, Denmark
}

Galster G. Contextualisation of clinical information from fragmented health records. Stud.Health Technol.Inform. 2013;194:41-47.

DOI: $10.3233 / 978-1-61499-293-6-41$ 
A part of this thesis has been removed from this publication due to copyright. 


\section{Bilag 5}

\section{Klinisk-logiske informationsstrukturer}

Dette bilag rummer eksempler på klinisk-logiske informationsstrukturer fra Frederiksberg-undersøgelsen, jf afsnit 8.3. 
A part of this thesis has been removed from this publication due to copyright. 


\section{Bilag 6}

\section{Identificerede kontekstualiseringsblokke}

Dette bilag rummer eksempler på identificerede kontekstualiseringsblokke dvs. oplysninger, som blev kontekstualiseret i sammenhæng - fra Frederiksberg-undersøgelsen, jf afsnit 8.3. 
A part of this thesis has been removed from this publication due to copyright. 